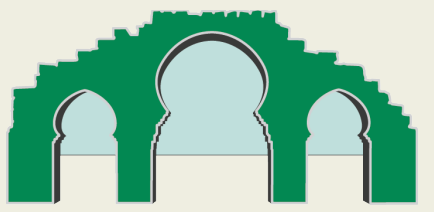

argelina.org

\section{Revista Argelina}

Revista semestral de Estudios Argelinos

Primavera 2019

Número 8

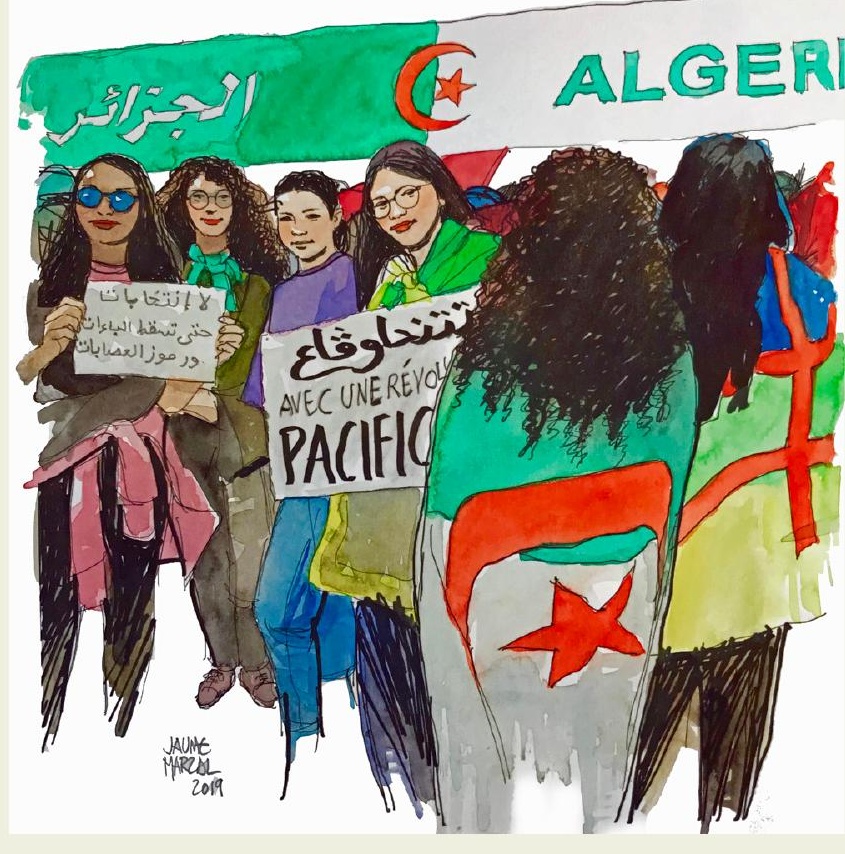

Universitat d'Alacant
Universidad de Alicante 
Número 8 · Primavera 2019

\section{Revista Argelina}

Revista semestral de Estudios Argelinos 



\section{Revista Argelina}

Revista semestral de Estudios Argelinos

Número 8

Comité editorial:

Directora: Naima Benaicha Ziani

Subdirector: Isaac Donoso

Editora: Oum Hani Rahmani

Secretario técnico: Didac Conesa

\section{Comité científico:}

Emilio Sola

Universidad de Alcalá de Henares

Abdallah Hammadi

Universidad de Constantina

Juan Martos Quesada

Universidad Complutense de Madrid

Carmen Barceló

Universidad de Valencia

Miguel Ángel Manzano

Universidad de Salamanca

Danielle Pister-López

Universidad de Lorraine

Fernando de Ágreda Burillo

Biblioteca Islámica-AECID

Laurence Thieux

Universidad Complutense de Madrid

Rafael Bustos García de Castro

Universidad Complutense de Madrid 


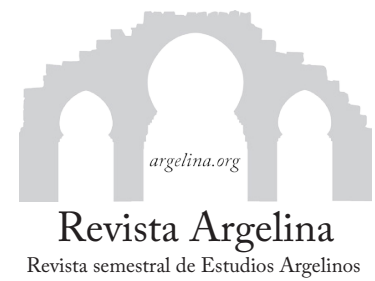

Revista Argelina. Revista semestral de Estudios Argelinos es una publicación electrónica semestral editada por el Área de Estudios Árabes e Islámicos de la Universidad de Alicante que edita dos números anuales de investigación y reflexión en torno a las letras, cultura, historia y actualidad de Argelia.

Una versión extendida de la revista se publica en papel por la Editorial Hispano-Árabe.

Cuenta con una Ayuda para la Publicación de Revistas Científicas del Vicerrectorado de Investigación y Transferencia de Conocimiento.

Exención de responsabilidad:

Las opiniones y datos contenidos en cada texto son de exclusiva responsabilidad de sus autores. Revista Argelina no comparte necesariamente las opiniones vertidas por los autores ni se hace responsable de los trabajos.

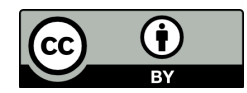

licencia de Creative Commons Reconocimiento 4.0 Internacional.

(C) De los autores de los artículos originales.

(C) Revista Argelina, 2019

ISSN: 2444-4413

La revista esta disponible a texto completo en internet en:

https://argelina.ua.es

http://argelina.org

\section{Portada:}

Revolución argelina 2019, acuarela original realizada por Jaume Marzal Canós.

Diseño y maquetación: Didac Conesa

Imprime:

Editorial Hispano-Árabe

http://www.editorial-hispanoarabe.com

Calle de los Jazmines № 17

Talamanca de Jarama

28160 Madrid

Tel. 639707720 


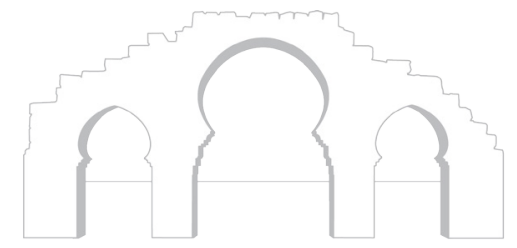

Revista Argelina $\cdot$ Número 8 $\cdot$ Primavera 2019

Índice

Editorial

Ensayos

Natalia Molinos Navarro y Jaume Marzal Canós

Argelia y España, un amor de ida y vuelta

Karim Aкouche

El futuro de Argelia en seis actos

\section{Artículos y notas}

Rafael Bustos García de Castro

El "hirak" popular: la nueva revolución argelina

Adel Abderrezak

Le mouvement populaire en Algérie : vers une rupture systémique ? Sur les racines socio-historiques de la crise algérienne

Brigitte Leguen

Le regard de Dib et Camus sur le paysage algérien 51

ILYA U. TOPper

La Izquierda social y el Islam político: la experiencia argelina

Laurence Thieux

L'Algérie transition incertaine sur fond de crise politique annoncée 75

Reseñas y comentarios bibliográficos

Nabil Ziani, Les berbères dans la Bible. Des origines à la fin des temps, (Naima Benaicha Ziani)

Hugh Roberts, Berber Government: The Kabyle Polity in Pre-Colonial Algeria (Antonio Torres Fernández) 91

Mustapha Chérif, Tolerancia e intolerancia en el islam (Isaac Donoso) 93 


\section{Biblioteca}

Wassyla Tamzali

El feminismo ante el Movimiento del 22 febrero: la revolución por las mujeres (Entrevista traducida del francés por Naima Benaicha Ziani)

AzIz Farès

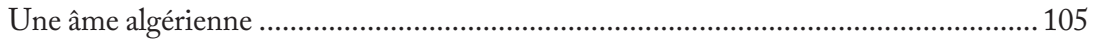

Titles \& Abstracts Addenda ............................................................................. 111 


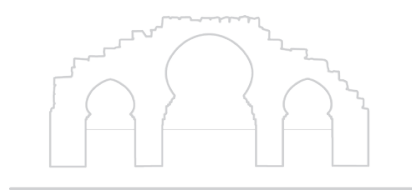

Editorial

Argelia tuvo su propia Primavera Árabe en el año 88 del siglo pasado. La segunda tuvo como escenario la Cabilia en 200r, bajo el nombre de Printemps noir, una especie de conmemoración del llamado Printemps berbère acontencido en 1980. No hubo reacción internacional a estas protestas. En solitario y sin que produjera efecto dominó, Argelia y los argelinos lucharon, sin armas, contra la inestabilidad política y el integrismo islamista. La tímida aparición de los nuevos medios de comunicación, entonces, no consiguió propagar el valor de estos movimientos ni lo hondo que llegaron a calar en las generaciones que hoy lideran y protagonizan la llamada "Revolución del 22 de febrero". Lejos de ser un movimiento aislado, la desencadenada revolución del siglo XXI desafía a un sistema político que se disputa entre el control del ejército y la persistencia del antiguo régimen del FLN, ambos liderados por octogenarios. Decisiva también para el Hirak, movimiento popular que derrocó recientemente al presidente Bouteflika. De igual manera, decisiva para los partidos de la oposición que no consiguen ponerse de acuerdo y que parecen estar en una encrucijada sin una aparente salida.

Dilem, el polémico caricaturista, condenado por sus atrevidos y reivindicativos dibujos, resume la historia de la Argelia independiente en un dibujo que no dejó indiferente a nadie: "La Guerra de Liberación se paró el 5 de julio de 1962 para retomar la lucha el 22 de febrero de 2019 ". A nivel internacional y por el respeto que le profesa al pueblo argelino, en una entrevista sobre el devenir político-social de los países árabes, Adonis, el poeta y pensador sirio, insiste en que el único país árabe capaz de convertir sus reivindicaciones en revolución es Argelia. Insiste, y sin intransigencias, en no comparar manifestaciones con revolución. Es hacia una resistencia pacífica que las nuevas generaciones argelinas se dirigen. Hoy y ante el peligro de quedarse atrapados en el pasado, los argelinos 
se plantean, seriamente, salir del estancamiento del pensamiento árabe y la crisis de la modernidad que sacude las sociedades árabo-musulmanas contemporáneas.

N. B. Z.

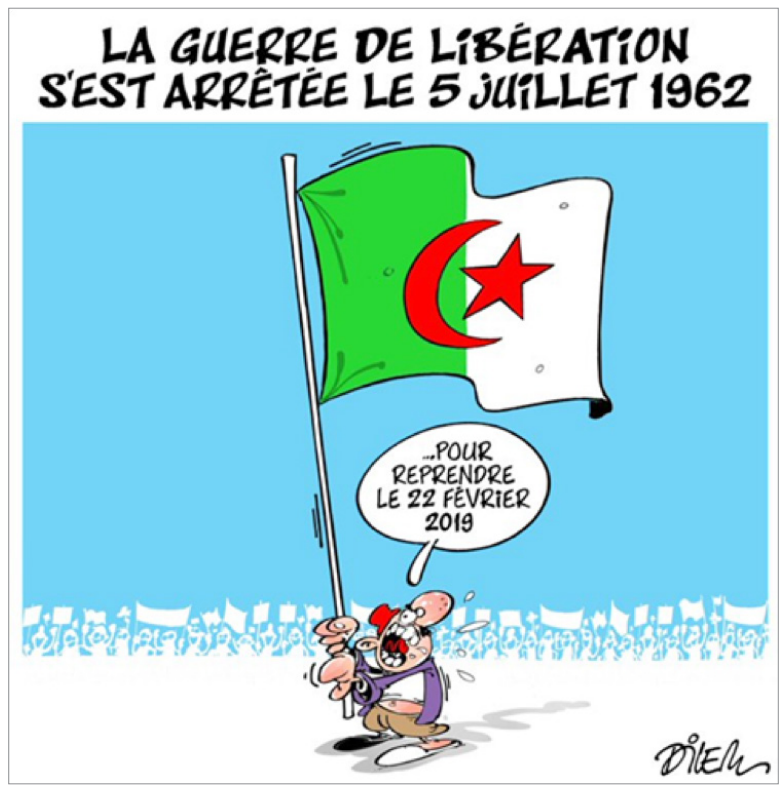

Fuente: Ali Dilem, periodista y caricaturista argelino. 


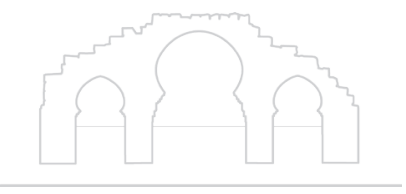

Ensayos 



\title{
ARGELIA Y ESPAÑA, UN AMOR DE IDA Y VUELTA
}

\author{
Texto: Natalia Molinos Navarro
}

Doctora en Patrimonio Cultural e Historia del arte

Imágenes: Jaume Marzal CaNós

Artista plástico

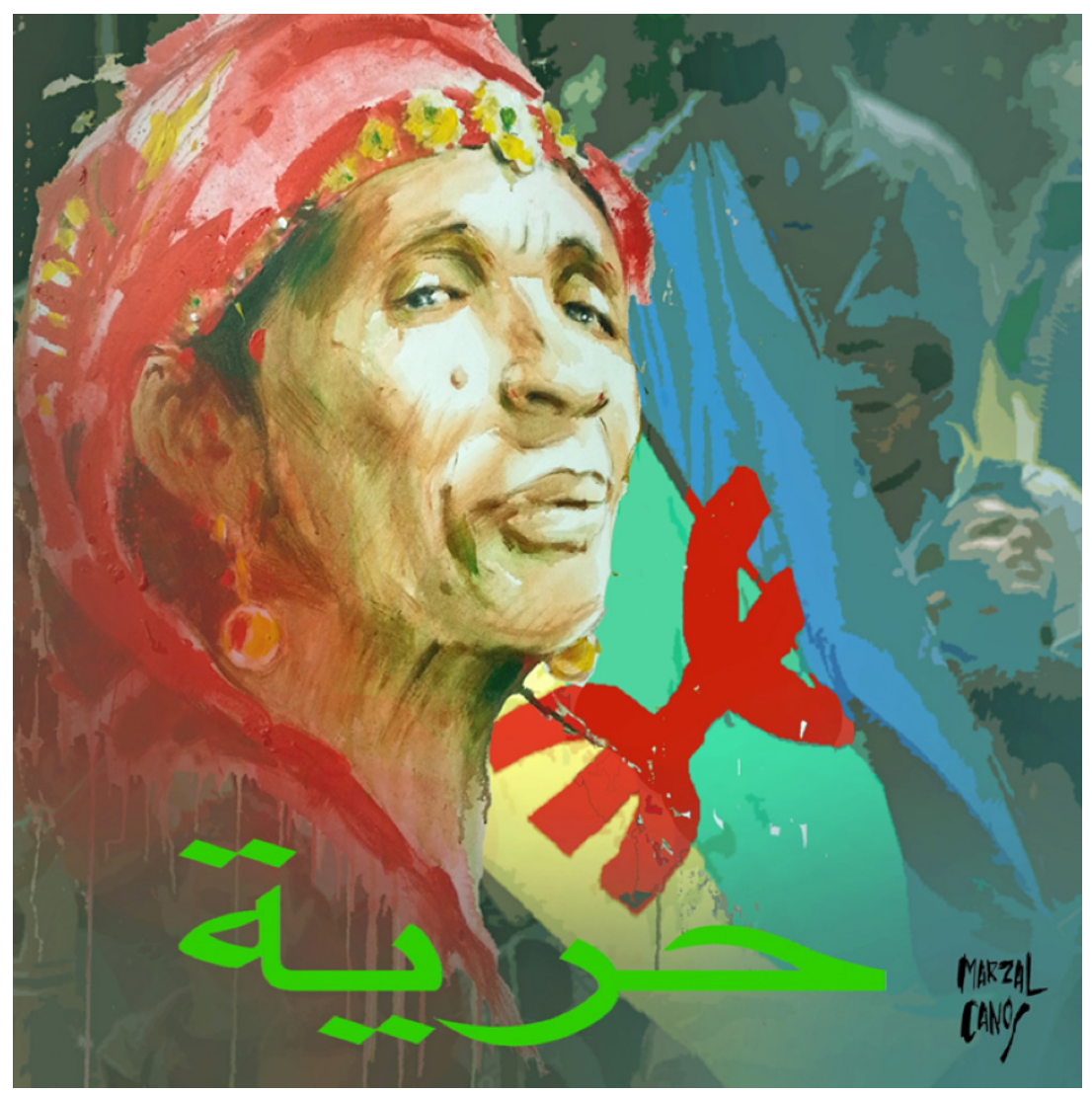

"Libertad", obra en técnica mixta 
Argelia está en estos días siendo el foco de atención del mundo por el proceso de democratización de impulso ciudadano que está viviendo. Un país con el que estamos mucho más vinculados de lo que percibimos, porque los españoles hemos sido parte de lo que ahora son los argelinos, como los argelinos forman parte de lo que ahora es España. Esta relación entre las dos orillas del Mediterráneo, proviene de siglos y continúa transformándonos, siendo ahora nosotros receptores de inmigrantes, como en otras épocas fue Argelia el país que nos acogió. Tan cerca y tan lejos.

Argelia se creó a partir de un crisol de culturas, credos, ideologías... Un país lleno de posibilidades de futuro, rico en materias como petróleo e hidrocarburos, con posibilidades turísticas de cientos de kilómetros de costa virgen, paisajes y monumentos como yacimientos arqueológicos, que, en la actualidad, están en peligro de perderse si no se actúa a tiempo. Un país cuyos ciudadanos reclaman mejorar sus sistemas educativos, sanitarios, culturales, porque saben que tienen unos derechos y quieren restablecerlos de manera pacífica. Conseguir una verdadera democracia significa para ellos empezar a obtener una mejor calidad de vida. España pasó por un proceso parecido.

Si España y el Magreb tienen una vinculación clara desde hace siglos, Alicante tiene desde el siglo XIX una significativa relación con Argelia. Desde antes de la colonización francesa del país, ya había alicantinos trabajando en los campos argelinos, pero es sobre todo a partir de la presencia francesa, cuando los alicantinos optan por buscar una nueva vida ante las penosas condiciones económicas de los años treinta y especialmente en los años cuarenta del siglo xIX en la provincia, con sequías tan enormes que la decisión estribaba entre quedarse a morir o marchar a la aventura. También las represiones políticas tras las guerras carlistas en el XIx, o tras la Guerra Civil de I936- I939 harán que el éxodo de alicantinos hacia Argelia les constituya como una gran mayoría entre las distintas nacionalidades que conformarán el país, marcando para siempre la personalidad de éste.

España, un país de tradición migrante sabe que la decisión de marchar casi nunca se debe a razones alegres y que cuando el número de inmigrantes es alto, suele implicar un malestar en el país receptor. Durante el siglo XIX, sobre todo en la década de I840, con una racha de sequía 
muy fuerte en el campo, y primeros años del siglo xx, los alicantinos que llegaron a Argelia fueron bien recibidos por los colonos franceses, sobre todo por sus dotes de agricultores, y en el caso de las mujeres, como ayas de crías o mujeres para la casa, siendo muy apreciadas. También fue importante su presencia en las minas, en la industria y en el comercio del esparto. Más tarde, la presencia de heladeros y de la industria del turrón en Argelia será notable, sobre todo en Argel, Orán y Sidi-bel-Abbés. Los alicantinos mantuvieron un idilio de ida y vuelta con su nueva patria, regresando cuando la situación era adversa, ya fuera por falta de trabajo o agresiones a extranjeros, o, en otros casos, al mejorar las circunstancias laborales en Alicante, ya que siempre hubo un flujo de trabajadores de carácter laboral temporal y otro que se trasladó permanentemente. Otro momento importante de emigración alicantina fue al final de la Guerra Civil, cuando desde el puerto de Alicante, último bastión republicano, los barcos trasportaron a miles de españoles a Argelia. No fue fácil desembarcar y cuando lo hicieron, una gran mayoría fue destinada a campos de concentración hasta final de la II Guerra Mundial. El retorno definitivo se dio durante la violenta revolución argelina de los años cincuenta que llevó a la descolonización en I962, y en la que los extranjeros y los argelinos afines a los franceses fueron víctimas de numerosos atentados. Los españoles empezaron a abandonar Argelia a finales de los años cincuenta regresando a España o marchando a América del Sur. Al llegar la Guerra de Independencia argelina, algunos españoles exiliados de la Guerra Civil optaron por ir a Francia y otros se quedaron en Argelia, apoyando al Partido Comunista del país. E1 5 de julio de 1962, Argelia, alcanza su independencia, tras dos referéndums positivos previos. Entre 196r y 1974, la nueva nación había perdido un millón de europeos, lo que repercutió muy negativamente al perder comerciantes, profesionales y mano de obra de calidad. Muchos argelinos "pieds noir"-los argelinos de origen europeo repatriados tras la independencia, en su mayoría franceses, y muchos también valencianos, sobre todo de Alicante- regresaron a sus raíces alicantinas.

Un artista tan emblemático para los alicantinos como Gastón Castelló es un claro ejemplo de la emigración a Argelia. Sus abuelos tuvieron que emigrar a mediados del siglo xIx para evitar la pobreza y la hambruna. 
Tras la Guerra Civil, temiendo las represalias del bando vencedor, fue el propio Castelló el que se exilió durante un tiempo a Argelia. Castelló está estrechamente ligado a la gran fiesta alicantina de Hogueras. Una fiesta que en Argelia se celebró también durante años importada por los emigrantes de nuestra provincia.

Otro artista afincado en Alicante nos ayuda a comprender el lazo que nos une con Argelia, es el pintor Jaume Marzal, que ilustra con sus imágenes este texto. Marzal nos contó sus primeras impresiones del país magrebí, una visión romántica a partir de los libros del francés nacido en Argelia, Albert Camús, y películas francesas legendarias como Pepe, le Moko, o la italiana La Batalla de Argel. Esta idea novelesca se trunca en su primera visita a Argel, en I991, formando parte de un grupo organizado por la Fundación Olof Palme para realizar un informe no oficial sobre la situación del país, para lo que se reunieron con partidos políticos y sindicatos. Entre las personalidades entrevistadas estaba, el primer presidente de la nación recién emancipada en I962, Ahmed Ben Bella.

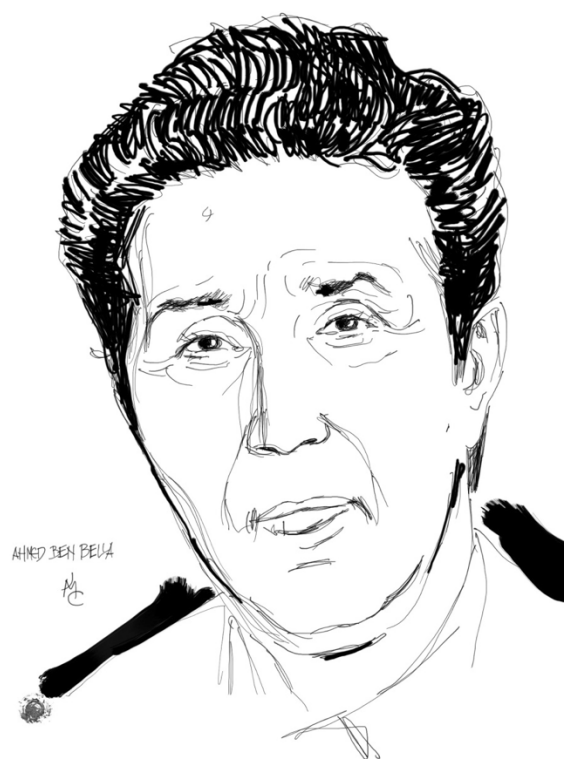

Ahmed Ben Bella, primer presidente de Argelia 
E1 momento era extremamente delicado, previo a una guerra civil que estalló poco tiempo después entre fuerzas del estado y rebeldes islamistas, un conflicto que duraría diez años, con más de doscientas mil muertes, incluidos muchos periodistas. El grupo viajaba constantemente con escolta y se sentía claramente el peligro. No hubo tiempo de dibujar, apenas el boceto del abogado defensor de los derechos humanos Ali Yahia Abdennour que impresionó a nuestro artista.

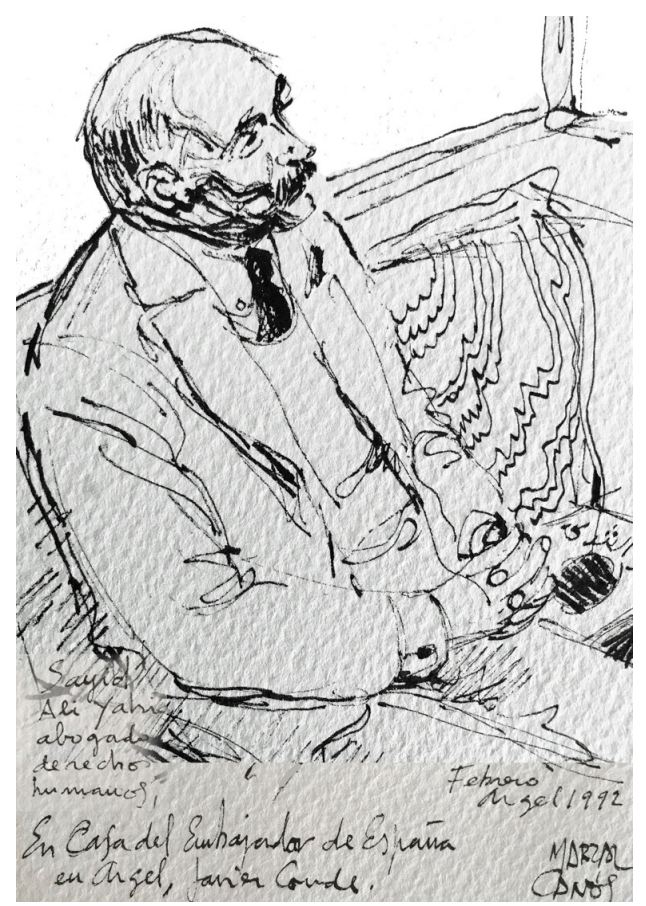

Ali Yahia Abdennour, abogado defensor de los derechos humanos

Pero de esta intensa experiencia surgió su interés por aprender la lengua árabe. Con el tiempo, Marzal ha viajado por muchos otros países árabes y en la actualidad desarrolla desde hace cinco años con el Colectivo Mediterráneo, Los Encuentros de Arte del Mediterráneo, en los que, a través de una exposición se muestran artistas de distintos países del arco 
mediterráneo. En su edición de 20r9, junto a otros, se ha contado con los jóvenes pintores argelinos Mouna Bonnamani y El Bardi. Marzal a través de ellos ha podido entender más de cerca el significado de la primavera árabe en Argelia y el momento actual por el que pasa la nación. Estas exposiciones suponen un intercambio cultural y de amistad y una ventana a culturas que estando cercanas, desconocemos.

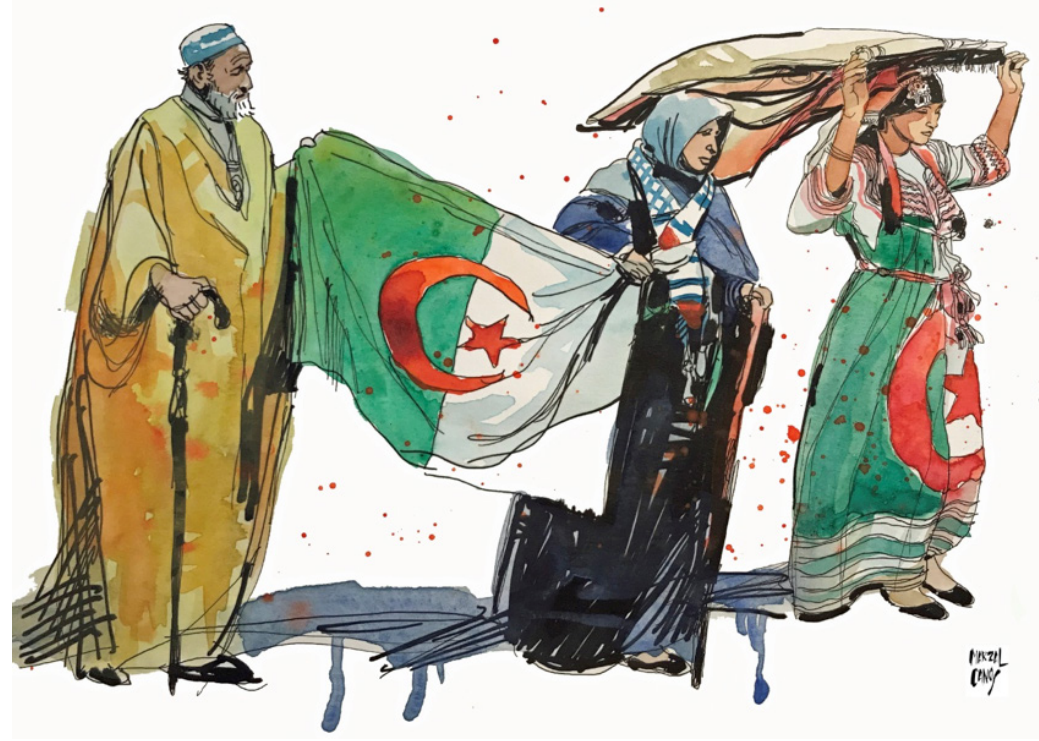

"Juntos en la primavera argelina", acuarela a partir de imágenes actuales de prensa

También en Alicante, la diplomática Casa del Mediterráneo en Alicante, lleva a cabo acciones para interrelacionar las culturas mediterráneas. Se dedicó un mes para difundir las posibilidades económicas y de futuro del país y su relación con España y Alicante. No en vano, uno de los destinos de los pieds-noir más importantes hacia el final de los años cincuenta y principio de los sesenta, sería nuestra provincia, que recuerda mucho geográficamente los paisajes argelinos. La misma Casa organiza, desde hace un par de años, ciclos sobre escritoras y realizadoras mediterráneas. 
Bahia Bencheikh El Fegoun, autora de H'na barra (Nous, dehors) (20I4), C'est à Constantine (2008) o Fragments de rêves (2013), en cada documental ofrece testimonios que llevan a la reflexión, desde la identidad de la mujer en el mundo musulmán, a los jóvenes que quieren conseguir un país más justo y democrático, al patrimonio nacional, logrando así hacer comprender para los foráneos toda una cultura y una forma de vida, pero buscando también encontrar la identidad actual del argelino, a través de conceptos e ideas que son universales y se nos plantean a todos los individuos durante nuestra existencia. Es el contacto directo con las personas lo que nos hace interesarnos, preocuparnos por ellas. Por eso es inevitable la atracción hacia el momento tan especial que se vive en este país hermano.

La cercanía entre Alicante y Orán, sólo doce horas en barco, y apenas una hora en avión, clima y paisaje parecido y costumbres similares, una situación sociopolítica complicada y una historia con muchos elementos comunes hace que en la actualidad, en la última década, miles de argelinos hayan decidido instalarse entre nosotros, convirtiéndose en el mayor grupo extranjero de compra de viviendas. El intercambio de orillas vuelve a aparecer, esta vez a la inversa, demostrando que Alicante y Argelia mantienen un amor de ida y vuelta.

\section{BIBLIOGRAFÍA}

Valdés Peña, Alba. "Alicantinos en Argelia, un viaje de ida y vuelta", Revista de Estudios Internacionales Mediterráneos, $\mathrm{n}^{\circ}$ Io (enero-junio 2OII).

VV.AA. "Alicantinos en el exilio 1939-1991", Revista Canelobre, no 20. Instituto Juan Gil-Albert, Alicante, I99I. 
18 Natalia Molinos Navarro y Jaume Marzal Canós

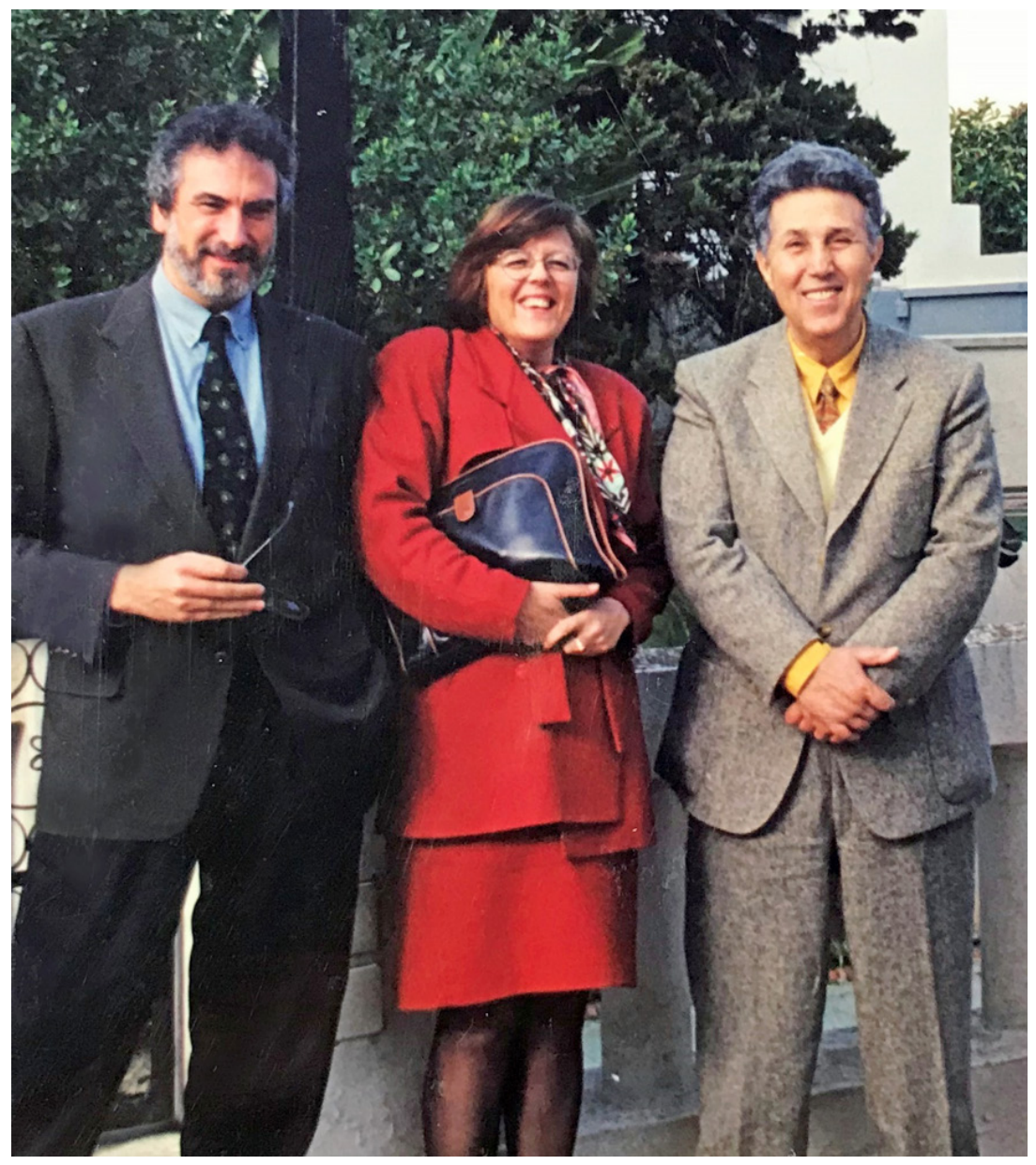

De izquierda a derecha: Jaume Marzal, Ana Balletbó y Ahmed Ben Bella en su residencia de Argel, año 1991. 


\title{
EL FUTURO DE ARGELIA EN SEIS ACTOS
}

\author{
Karim Aкоuche \\ Escritor
}

LA REVOLUCIÓN DEL Io DE NOVIEMBRE DE I954 Y SU DERIVA HISTÓRICA

Desde la independencia de Argelia todo, o casi todo, se ha malinterpretado: la constitución, las instituciones, la historia y la memoria gubernamentales, el himno, la bandera y los valores. Desde el principio, entre elegir maleta o ataúd, los que verdaderamente lucharon contra el colonialismo francés fueron apartados del poder por el llamado "clan de Oujda”. En un paracaídas y enviado por sus amigos del occidente, Ben Bella tomó las riendas del país en contra de los del oriente: cabilios y chaouis. En un acto de rebeldía, los partidarios de Hocine Ait Ahmed tomaron las armas en 1963 y más de 500 rebeldes fueron asesinados en el Djurdjura. Así, los primeros cimientos del estado argelino fueron manchados con la sangre de los opositores cabilios. En lugar de construir una nación sobre una base sólida, con las lenguas y culturas del pueblo en toda su diversidad, unos años más tarde, Boumediene prefirió importar costumbres y creencias de Egipto y de Arabia Saudi. “¡Argelia es una e indivisible, un país árabe y musulmán!”, clamaban los dignatarios del régimen en todos los foros. Resultado: Argelia está fracturada a todos los niveles y un río de malentendidos separa el estado de la nación, el poder del pueblo, Tremecén de Tizi-Ouzou, Argel de Ghardaïa, los bereberes de los arabófonos, las mujeres de los hombres...

Desviado de su espíritu universal, el proyecto revolucionario no se llevó a cabo. El sol de la independencia se desvaneció tan pronto como nació. Los franceses se fueron y la Argelia francesa dio paso a una Argelia artificial, fundamentalmente árabe e islámica. Privado de sus identidades amazigh, africana y mediterránea, el argelino se convirtió en el Otro. Como un extraño en su propio país, se busca a sí mismo, flotando a merced de los vientos ideológicos de otros lugares. Lo convertimos en 
una persona ajena, un sujeto separado de su patria; si cabe, más árabe y musulmán que el propio saudí.

En la escuela, en la administración y en todas partes había que desalojar la lengua de De Gaulle y sustituirla por la lengua de los tiempos del Profeta, el árabe clásico, que la gente apenas comprende. Al igual que los colonos franceses que hablaron a los autóctonos de "sus antepasados, los galos", los maestros argelinos les contaron a los niños las epopeyas de los califas y de "sus antepasados, los árabes". La historia ha sido falsificada en los libros de texto, las raíces del pueblo han estado, durante mucho tiempo, ocultas, y les han inventado a los bereberes orígenes yemeníes. Cuando éstos alzaron la voz y reivindicaron sus derechos, fueron acusados de servir a los intereses del Hizb França, el "Partido de Francia".

\section{DE LA REBELIÓN DE LA SONRISA A UNA VERDADERA REVOLUCIÓN}

Un fuerte e inesperado viento azota Argelia desde 2019. Habiendo derribado el muro del miedo ¿̨la juventud argelina derribará finalmente la montaña de los tabúes? Es de valientes estar en contra de un sistema tiránico. A esto se le llama revuelta, pero no es suficiente; mostrarse a favor de otro proyecto de sociedad, sostenible, abierto e inclusivo, es decir, hacer la revolución de mentalidades, esto es aún mejor, pero esta tarea es delicada, porque Argelia está atravesada por diversas corrientes ideológicas que se oponen entre sí.

No se construye una democracia con emociones, sino con debates, ideas, tinta y sudor. Todas las preguntas, incluso las más molestas, deben ponerse sobre la mesa. El lirismo debe dar paso a la razón.

\section{PLAN EN SEIS ACTOS}

Acto 1: Liberar a la mujer

No se puede construir un país con la mitad de su gente. Sin mujeres, los argelinos erigirán un país a medias, como mucho varonil, peludo, cojo, que sólo funcionará apoyado en muletas. El Código de Familia que ha hecho del sexo femenino un siervo con vestido o con velo, debe ser abolido de inmediato. El patriarcado y sus derivados deben ser desahuciados de los pueblos y de las ciudades. Las ágoras, asambleas de pueblos, 
asociaciones, instituciones, empresariado, ciencias y artes deben abrir sus puertas a las mujeres. Sin ésta y muchas otras rupturas de mentalidades, la revolución argelina, tan soñada y cantada, no tendrá lugar.

Acto 2: Liberar la historia

La historia es la base de cualquier país. Escribirla con la tinta ideológica de un partido, interpretarla según los caprichos de los gobernantes o de los gobernados, es traicionar a quienes la han protagonizado. Al no ser propiedad de nadie, debe permanecer neutral, ecuánime, constantemente interrogada, pero su escritura debe estar reservada para los especialistas. En Argelia la historia oficial ha sido disfrazada, pisoteada desde la independencia, violada por los dignatarios del régimen. Convertimos a los argelinos, en su mayoría amazigh, en árabes. De esta manera, construimos La maison Algérie sobre paja, ceniza, sobre terrenos artificiales; los pilares no sostienen las paredes, el techo no protege a los niños de las intemperies ni de los conflictos; todo es frágil, artificial, maquillado. Al renunciar a su verdadera historia, Argelia sigue vagando entre Oriente y Occidente. Doblemente acomplejada, titubea entre Okba y Napoleón. Esquizofrénica, es la hija adoptada de Egipto, igual que fue hija ilegítima de Francia. Sus hijos, desarraigados, flotan a merced de los vientos venidos de otros lugares. Los argelinos no son ciudadanos, sino seres desposeídos. Mientras sigan llevando la piel del Otro, la revolución de la sonrisa sólo será una quimera.

\section{Acto 3: Laicidad}

El Islam es la última religión que los bereberes han abrazado. Tenían sus propios demiurgos antes de ser influenciados por otros dioses: entre otros, eran, paganos, judíos, cristianos, antes de convertirse en musulmanes. El Islam ciertamente los ha islamizado, pero son ellos especialmente quienes han adoptado al Islam, dicho de otra forma, lo adoptaron adaptándolo a sus valores, inyectándole la filosofía de sus antepasados. Como las ciudades eran laicas antes de tiempo, siempre velaban porque el poder político y el poder religioso estuvieran separados. Al hacer del Islam la religión del estado en 1962, los líderes argelinos han asaltado la 


\section{Karim Akouche}

fe pacífica de los antepasados, han profanado su espíritu aperturista y su libertad de conciencia y, en el mismo sentido, favorecieron una única doctrina de Estado en detrimento de otras creencias. Al institucionalizar el Islam con fines políticos o, más concretamente, la política con fines islamistas, alimentaron a un monstruo que, décadas más tarde, destruiría el país. Al ser una caja de varios programas que combinan fe, política, cultura y justicia, el Islam debe ser privativo. Mientras que el Islam sea considerado como una constante intocable, un lema del Estado y de la escuela, una identidad nacional argelina, colocado sobre todo conocimiento, sacralizado y evitado por la razón crítica, la tolerancia y la tranquilidad del pueblo esperarán, y la revolución argelina, tan cantada y soñada por los jóvenes, no tendrá lugar.

Acto 4: Salir del racismo lingüístico

No somos necesariamente lo que reflejamos, sino lo que, sobre todo, expresamos. La identidad es un abanico de atributos, pero es, ante todo, la lengua. Es, en efecto ella quien da forma al alma colectiva de un pueblo, traza su destino, forja sus valores y manifiesta sus utopías. Al favorecer la lengua árabe en detrimento de las lenguas indígenas, las lenguas amazigh, la constitución argelina institucionalizó "la preferencia nacional árabe". En otras palabras, oficializó el racismo lingüístico. Sin mover ni una coma, conservó el Código del Indígena de la Francia colonial, lo aplicó a los bereberes y los hizo ciudadanos de casta inferior. Para una cabilio, un chaoui, un mozabita o un targui, el idioma árabe, a pesar de sus ventajas, no es una lengua inocente. Es, igual que lo fue el francés antes de la independencia, el idioma del colonizador. La política de arabización de los nativos, practicada con vehemencia por los dirigentes argelinos a partir de I962, es un crimen de identidad. Desfiguró los verbos y los objetos, mató a nombres y lugares, falsificó los cuentos y las costumbres. Cada vez que se pone de relieve el idioma árabe, un idioma favorecido constitucional y financieramente, los descendientes de Yugurta son humillados y la brecha de malentendidos que los separa de sus hermanas y hermanos argelinos se ensancha. La competencia lingüística provoca los odios y el rechazo del Otro. Mientras exista esta jerarquización de las lenguas y de las culturas 
donde, con toda seguridad, la diglosia se imponga, la alegre revolución, tan cantada y soñada por los argelinos, no tendrá lugar.

Acto 5: Etiología de la democracia argelina

La democracia argelina no existe, apenas si está en su etapa inicial. Para que, realmente, llegue a existir y que más tarde pueda madurar, necesita ser educada en la razón, alimentada por el debate y el pensamiento, lejos de la fe y de las emociones, alejada del folclore, rediseñada por el criterio de la Historia del país y de nuestro tiempo globalizado e impredecible.

Al menos, tres frenos bloquean la locomotora de la democracia argelina: el tribalismo, el selectivismo y el exclusivismo histórico. La democracia argelina o, para ser más exactos, su ersatz es etnicista, porque los ciudadanos no votan de acuerdo con sus creencias para un proyecto, ideas o partido, sino para las personas de su clan, región o tribu (el tremecení siempre ha votado por candidatos del oeste, como el cabilio para alguien de su región). Además, la democracia argelina es selectiva: los temas se eligen y los tabúes se ocultan: (el Islam, los orígenes del mundo, las raíces del pueblo, la sexualidad, el psicoanálisis, las mujeres, etc.). Por último, los políticos no derivan su credibilidad del debate de ideas y del juego democrático, sino, a menudo, de la legitimidad histórica o del supuesto derecho de primogenitura.

Hasta que no se rompan todas estas cadenas, y estos tres frenos no sean acribillados, la locomotora de la democracia argelina no se iniciará y la revolución, tan cantada y celebrada por la multitud, esperará un largo tiempo.

Acto 6: Unidad y diversidad argelinas

No se diseñará un nuevo Estado, moderno y justo, si no se rompe radicalmente con el contenido y con todo que le precede, es decir, si no se hacen dos revoluciones paralelas, institucional y de civilización, jurídica y cultural. Si se quiere evitar caer en el folclore y el amateurismo, el movimiento ciudadano argelino debe reflexionar, a corto y largo plazo, 


\section{Karim Akouche}

tanto sobre el sistema de gobernanza que se ha de adoptar como sobre los valores de las futuras instituciones.

Algunos de nuestros demócratas, formateados por el software FLN pretenden ya delimitar el debate cuando el proceso constituyente todavía no se ha iniciado. Oleadas y populistas, confunden «unidad», «uniformidad», «unión», «uniformismo»... Para obtener el consenso de los argelinos, es necesario, en primer lugar, apostar por sus diferencias, ya que ocultar previamente sus contrastes, alimentarán a éstas y les darán la oportunidad de vengarse de la democracia en una etapa posterior.

Si se mira a Argelia con sinceridad y frialdad, nos daríamos cuenta que se compone de un mosaico de naciones y de lenguas. Un estado centralizado y jacobino, sofocaría las culturas e identidades que lo componen. El federalismo o regionalismo positivo, flexible de acuerdo con los deseos e intereses de las provincias, se adaptaría a la realidad social del país y, una vez consolidado, federaría los estados regionales y evitaría la fragmentación del Estado nacional. Sin ello, la revolución de la sonrisa, tan cantada por las multitudes y consagrada por los observadores, no se llevará a cabo.

\section{CONCLUSIÓN}

Argelia es un mosaico de pueblos y de culturas, y una república aperturista y laica parece el mejor escenario para su mejor desarrollo. La democracia selectiva, el favoritismo lingüístico y religioso, la negativa a mirarse en el espejo para corregir sus desperfectos, la autosuficiencia y el rechazo de la razón crítica serán obstáculos en el camino del nuevo Estado. El antiguo régimen no es viable. Los horizontes se abren y los desafíos son enormes para un pueblo joven y capacitado. 


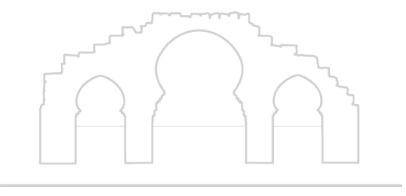

Artículos y Notas 



\title{
EL "HIRAK" POPULAR: LA NUEVA REVOLUCIÓN ARGELINA
}

\author{
Rafael Bustos García de Castro \\ Universidad Complutense de Madrid
}

\begin{abstract}
Resumen
En este artículo se analiza la singularidad del movimiento popular conocido como Hirak argelino, en el que se explican sus diferencias con las primaveras árabes y también con episodios previos de cambio político vividos en Argelia (I988-I992), ya que este movimiento extrae sus raíces de la guerra de independencia y es fundamentalmente pacífico. Igualmente se discute el impasse actual tras haberse agotado el cauce constitucional y las posibles vías hacia una transición que se están discutiendo, así como algunas de las reacciones internacionales que hasta ahora se han producido.
\end{abstract}

Palabras clave: Argelia, Hirak, manifestaciones, primavera árabe, guerra de independencia, empoderamiento, reacciones internacionales, transición democrática y sociedad civil.

\begin{abstract}
This article argues that the Algerian Hirak protest movement is a singular and exceptional case, which differs from both the "Arab Spring" and the "Algerian Spring" (1988-1992). It draws its special characteristics and strength from the Independence War (I954-I962) while it is mainly being conducted through peaceful means. We also examine the current situation of political impasse once the Constitutional procedure has been exhausted and the possible paths to democratic transition that are now being discussed, taking a look at how the most notorious international actors have so far reacted to the Algerian Hirak.
\end{abstract}

Keywords: Algeria, Hirak, demonstrations, Arab Spring, Independence war, empowerment, democratic transition and civil society.

\section{INTRODUCCIÓN}

Los hechos que comenzaron el 22 de febrero de 2019 - con una oleada de indignación al conocerse la candidatura de Abdelaziz Buteflika a un quinto mandato - no han dejado de asombrarnos y como a nosotros a todos los buenos observadores de la realidad argelina. La protesta argelina o birak asháabi es un movimiento popular que ha ido adquiriendo unas dimensiones poco usuales, que rompen con episodios anteriores vividos 
tanto en Argelia (I988-I992, 200I) como en otros países árabes durante las pasadas "primaveras árabes" (20II-20I3).

Por un lado, llama poderosamente la atención la fuerza y la determinación, por otro, la originalidad, el sentido del civismo y la creatividad de las expresiones de protesta. Juntas, estas características están produciendo un efecto totalmente inesperado y audaz: el empoderamiento de una sociedad traumatizada, junto al desmantelamiento progresivo del régimen buteflikista y su deslegitimación a ojos de la opinión pública argelina e internacional, lo que tiene por consecuencia un careo de fuerzas entre el ejército y el movimiento popular, tras el que se esconden muchos otros actores, pero que obliga a cada uno de ellos a escribir su papel y tomar posición.

A nivel internacional, el mundo se encuentra en una fase de gran convulsión, inmerso en rivalidades geopolíticas y guerras comerciales de gran amplitud, que hacen que para bien o para mal las movilizaciones argelinas estén pasando con relativa discreción, a pesar de su singularidad y el potencial inspirador que poseen. Esto explica que de momento hayan sido escasas y muy medidas las declaraciones de líderes mundiales: tanto de los occidentales como de las autoridades políticas de Rusia, China o de Oriente Medio. Pero no hay duda que estos movimientos son seguidos y observados por las cancillerías y gobiernos, algunos de los cuales alientan sin disimulo objetivos contrarrevolucionarios.

\section{ESPECIFICIDAD}

Es difícil poner una etiqueta a estas protestas argelinas, no encajan bien con las que circulan con más éxito en los medios de comunicación. El Hirak argelino no casa con las primaveras árabes porque es a la vez mucho más profundo y menos manipulable. Aquellas se distinguieron por demandar y conseguir derribar a los gobernantes de turno, si bien sus lemas iban contra todo el sistema "al-sha'ab iurid isqat al-nitham", se contentaron con la huida o destitución de los gobernantes y salvo escasas excepciones - Túnez - no lograron rescribir las reglas del sistema político. Las primaveras árabes fueron muy mediáticas y sufrieron un fuerte impacto foráneo, de fuerzas que por un lado alentaban a los manifestantes (EEUU con B. Obama, Turquía, al-Jazeera, etc.) y por 
otro, ayudaban a la represión de los mismos (Arabia Saudí en Bahréin o en Yemen). Estuvieron hondamente penetradas por la cuestión del islamismo, un factor ajeno a las mismas, pero que acabó provocando una injerencia desestabilizadora.

Sin embargo, el Hirak argelino ha sido un movimiento que enraíza con la guerra de independencia (I954-I962), que remite a las reivindicaciones políticas — no resueltas - de aquel período y que replantea prácticamente todo el período post-colonial de la Argelia independiente ${ }^{1}$. Es un movimiento transversal, inter-generacional y de carácter nacional, sin que quepa apropiación del mismo por ningún partido, movimiento, sector o región del país. Se trata de una forma de organización social que rechaza expresamente la instrumentalización por parte de los islamistas (abucheados y apartados de las concentraciones ciudadanas en los pocos lugares donde se han visibilizado) o de los poderes extranjeros, a los que se ha exhortado en múltiples pancartas a mantenerse al margen (Francia, EEUU, Emiratos Árabes Unidos, Arabia Saudí). Sus demandas son profundas y no van a detenerse por los éxitos puntuales como la renuncia del expresidente a un quinto mandato, ni por su dimisión como jefe del Estado, ni siquiera por la anulación de unas elecciones sin garantías, como las que se anunciaron para el 4 de julio. Tampoco se contenta con una justicia de apariencias, con una campaña instigada por el ejército de detenciones y arrestos domiciliarios, por muy espectacular que sean las figuras en prisión, porque saben que la verdadera justicia sólo puede surgir en un sistema democrático que garantice el estado de derecho.

A diferencia de lo que sucedió en el período de I988-1992, ${ }^{2}$ los acontecimientos de ahora están caracterizados por el aprendizaje colectivo. Las generaciones del hirak actual han vivido en algunos casos los hechos tristes del "decenio negro" de violencia y terrorismo (I992-200I) pero,

1 Esta misma es la opinión del especialista Francis Ghilès, quién así lo afirmaba en una columna de opinión reciente aparecida en el diario El Watan y republicada en el portal Algeria-Watch: "Ce qui se passe à Alger n'est pas un énième épisode du Printemps arabe. C'est une volonté de renouer avec la Révolution de 1954-1962 qui a été confisquée [...]. Ghilès, F. «Une Algérie debout et fière». El Watan. Argel. 6/03/2019. disponible en: https://algeria-watch.org/?p=71337.

2 Puede verse, a este respecto, mi tesis doctoral Bustos García de CAstro, R. El cambio político en Argelia (1988-1992). Análisis sistémico de una transición discordante. Universidad Complutense de Madrid. Departamento de Estudios Internacionales. Tesis doctoral. Petschen, S. 
sobre todo, los más jóvenes se han socializado en los mismos a través de sus familias, los relatos, el éxodo y el dolor. De ese aprendizaje colectivo, resulta una gran madurez, más aún si cabe que se trata de un movimiento sin líderes visibles, un movimiento nacional que se niega expresamente a señalar o elegir a sus representantes. En consecuencia, el birak argelino evita toda confrontación, adopta como lema consignas y acciones pacíficas como "simiyya, silmiyya" o "al-sha'ab wa al-yaish, khawá-khawä". Las marchas son organizadas de manera eficaz para minimizar los enfrentamientos, con los voluntarios "chalecos naranjas" que previenen y asisten a las personas que sufran algún desmayo o impacto, para luego evacuarlas y dejar limpias las zonas por donde discurren los ciudadanos en protesta.

La lección está magníficamente aprendida, hay que evitar toda provocación, toda instrumentalización por parte de grupos, partidos o movimientos. No se debe facilitar la cooptación y la división desde arriba y por ello no se eligen, al menos de momento, portavoces ni interlocutores del movimiento. Todo resulta bien organizado y eficaz, en el terreno con los "chalecos naranjas" y en Internet con ayuda de las redes sociales, entre las que destacan Facebook y Twitter, medios que por otra parte no estaban todavía al alcance en I988, ni en 200I, ni siquiera masivamente en 2011. Estos medios ayudan a mostrar el lado simpático, humorístico y divertido que también tiene el hirak argelino. Hay una expresión y profusión de mensajes que utilizan varios registros al mismo tiempo y apelan al conocido humor argelino, como los relacionados con el "Kachir", por poner solo un ejemplo, la salchicha kosher, que por todo el país simboliza los lujos de la clase dirigente y su corrupción. O el famoso "Yetnahaw ga'a", verdadero hasthag de Twitter y emblema de innumerables camisetas y pancartas, de difícil traducción, pero que vendría a ser algo como "Que se vayan todos o todos fuera".

\section{PROBLEMÁTICA Y REACCIONES}

Hasta aquí I8 semanas seguidas de protestas cuando escribimos estas líneas, especialmente los martes (estudiantes) y los viernes (toda la sociedad), que no han disminuido pese a estratagemas como adelantar y ampliar las vacaciones estudiantiles, dejar que la red de Internet caiga los viernes, provocar cortes de tráfico en las arterias de la capital y distraer a 
la ciudadanía con procesos judiciales fugaces o "fantasmas". Tampoco el Ramadán y el comienzo del calor estival han desanimado a los asistentes, que con los cánticos de los estadios (La Casa del Muradía, en alusión al palacio presidencial), y otras muchas canciones han animado y extendido el hirak, provocando lo que no deja de ser admirable: la transformación de un pueblo, de una sociedad profundamente traumatizada por la violencia y el miedo, en un país que se siente empoderado, que sale a la calle, se apropia del espacio público y persevera en sus reivindicaciones hasta que se cumplan.

Llega un momento no obstante en que estas dinámicas sólo dejan ver, engañosamente eso sí, dos actores, el pueblo y el ejército. Como si la sociedad argelina fuera reducible a esa simple y burda dicotomía. Llega también el momento en que la situación política y económica deben avanzar. El país no puede soportar una parálisis indefinida, como es natural. $Y$ en ese momento es cuando es necesario empezar a articular una representación política. Algo así empezó a producirse el I5 de junio pasado cuando diversas organizaciones y plataformas de la sociedad civil, se reunieron en Argel para acordar una trabajada hoja de ruta, en la llamada Conferencia Nacional de la Sociedad Civil ${ }^{3}$. Allí estaban colectivos de sindicatos independientes, organizaciones ya clásicas como la Liga Argelina por la Defensa de los Derechos Humanos LADDH, SOS Disparus por las familias de los desaparecidos, junto con el Comité Nacional de Defensa de los Derechos de los Parados CNDDC, y organizaciones de estudiantes, mujeres, etc. Paralelamente los partidos políticos de oposición, aunque por desgracia, no están todos, se están concertando de cara a ese plan venidero; por eso firmaron una declaración común el pasado I8 de junio un total de 7 partidos de tendencia laicista: FFS, RCD, MDS, PT, PST, PLD y UCP. ${ }^{4}$

Las personalidades políticas se están expresando con respecto a esa transición que se vislumbra en el horizonte. Personas como militares re-

3 Véase Aichoun, A. «Conférence nationale de la société civile le 15 juin : Cap sur la transition ». El Watan. Argel. 09/06/2019. disponible en: https://www.elwatan.com/a-la-une/conferencenationale-de-la-societe-civile-le-15-juin-cap-sur-la-transition-09-06-2019.

4 Véase RFI. «Algérie: 7 partis d'opposition se fédèrent pour sortir de l'impasse politique ». Radio France International. Paris. 20/06/2019. disponible en: http://www.rfi.fr/afrique/20190620algerie-7-partis-opposition-federent-sortir-impasse-politique. 
tirados de gran prestigio, antiguos ministros y primeros ministros (Hadj Nacer, Hamrouche, por ejemplo) se están pronunciando sobre cuál sería el itinerario más conveniente. $\mathrm{Al}$ mismo tiempo se operan cambios importantes en la Patronal (Forum des Chefs d'Entreprises, FCE) y el Sindicato mayoritario (UGTA), una vez que el jefe de la patronal fue detenido y el Secretario General de la UGTA, con varias décadas en el cargo, ha renunciado a seguir, debido a las fuertes críticas internas. Un personaje histórico del buteflikismo que recientemente también ha sido llamado a comparecer ante los tribunales.

Con todo, hay dos posibilidades de salida o de transición que siguen discutiéndose a día de hoy, y cualquiera de las dos implica desbordar el plano constitucional vigente. $\mathrm{O}$ bien se prepara una Asamblea Constituyente a través de un proceso de confluencia de las fuerzas vivas del país y después se elige al nuevo jefe de Estado; en este escenario, debería haber una presidencia colectiva provisional formada por dos o tres personas independientes y respetadas que asuman la jefatura del Estado hasta el final del proceso. $\mathrm{O}$ bien, se hace al revés, es decir, se trabaja primero en la preparación de unas Elecciones Presidenciales creíbles, algo que no puede hacerse con las instituciones estatales vigentes, y después se pone en marcha el proceso constituyente. El orden de los factores no es baladí y ha costado muchas discusiones a las asociaciones de la sociedad civil argelina. Una cuestión central independientemente de la vía es con quién y con qué actores del actual régimen se puede y se debe dialogar. Pero lo que está claro es que tanto la vía $\mathrm{A}$ como la vía $\mathrm{B}$ requieren dar un paso al margen de la Constitución. Esto es justo lo que más asusta al Ejército y a su jefe máximo, el general Ahmed Gaïd (Qaid) Salah. El ejército ha tratado hasta ahora y por todos los medios de no salirse del guion constitucional, algo que empieza a no ser posible, una vez que superada la fecha del 7 de julio, el jefe de Estado provisional no ha logrado convocar elecciones a la presidencia para las que fue nombrado, anuladas las del 4 de julio y concluido el periodo legal de 90 días.

Por último y no menos importante, está el papel de otros actores internacionales. Argelia conoce muy bien hasta dónde pueden llegar esas influencias, tanto por su reciente historia política como por la de países del Sahel como Sudán, que está sufriendo precisamente en estos mo- 
mentos las consecuencias menos deseables de la intervención extranjera a petición del gobierno de turno. De ahí el énfasis de muchos carteles, como decíamos en mantener a cierta distancia a actores tan importantes como Francia, EEUU, Emiratos o Arabia Saudí. Así, por ejemplo, la intervención del presidente Emmanuel Macron, saludando la retirada de Buteflika y llamando a realizar "una transición en un plazo razonable" 5 suscitó vivas respuestas de oposición entre los argelinos de Argelia y de Francia. También los carteles, como puede observarse en la imagen más abajo, sobre las relaciones entre las Fuerzas Armadas argelinas y Emiratos Árabes Unidos, país conocido por su papel contra-revolucionario en la caída del recientemente fallecido presidente Mohamed Morsi, o en obstaculizar el joven gobierno democrático de Nahda en Túnez son sintomáticos de que los argelinos hacen bien en desconfiar de los acercamientos que llegan del Este o del Oeste. Por su parte, Rusia se ha mostrado cautelosa, indicando que se trata de un asunto exclusivamente argelino en el que no quiere que ningún país se entrometa ${ }^{6}$, dando a entender que su posición es más afín al régimen que a la oposición o los manifestantes.

\section{CONCLUSIONES}

El hirak argelino es un movimiento formidable, auténticamente singular, que no está teniendo un gran eco mediático pese a su potencia, eficacia y al mensaje liberador que está vehiculando. De momento, sus éxitos se pueden enumerar y se celebran, pero ha llegado el momento más importante y quizá el más difícil: aquel en el que comienza la transición, se ha de negociar por un camino que no está escrito. Ya no vale la senda constitucional porque ha quedado ampliamente superada y al mismo tiempo negociar exige elegir representantes. Es decir, exige articular una representación, algo que hasta ahora se ha evitado inteligentemente por

5 Véase LE-MondE. « Algérie : Macron appelle à « une transition d'une durée raisonnable » après le renoncement de Bouteflika ». Le Monde. París. 12/03/2019. disponible en: https://www.lemonde. $\mathrm{fr} /$ afrique/article/2019/03/12/algerie-macron-appelle-a-une-transition-d-une-duree-raisonnableapres-le-renoncement-de-bouteflika_5434750_3212.html.

6 Véase Baвоuсне, Y. «La Russie apporte son soutien au pouvoir algérien, met en garde les autres pays ». Tout sur l'Algérie. Argel. 19/03/2019. disponible en: https://www.tsa-algerie.com/ la-russie-apporte-son-soutien-au-pouvoir-algerien-met-en-garde-les-autres-pays/. 
temor a la cooptación y la manipulación de los servicios secretos argelinos, expertos en ese arte. Es el momento de articular un liderazgo y de avanzar en la hoja de ruta de la sociedad civil, a la que deben sumarse todos los partidos de oposición, sin distinción ideológica. Una propuesta clara y conocida debe ver la luz con urgencia pues el impasse político y económico que vive el país no puede prolongarse muchos meses más. El empoderamiento de esta sociedad argelina al que estamos asistiendo permite ser razonablemente optimistas sobre sus posibilidades de éxito.

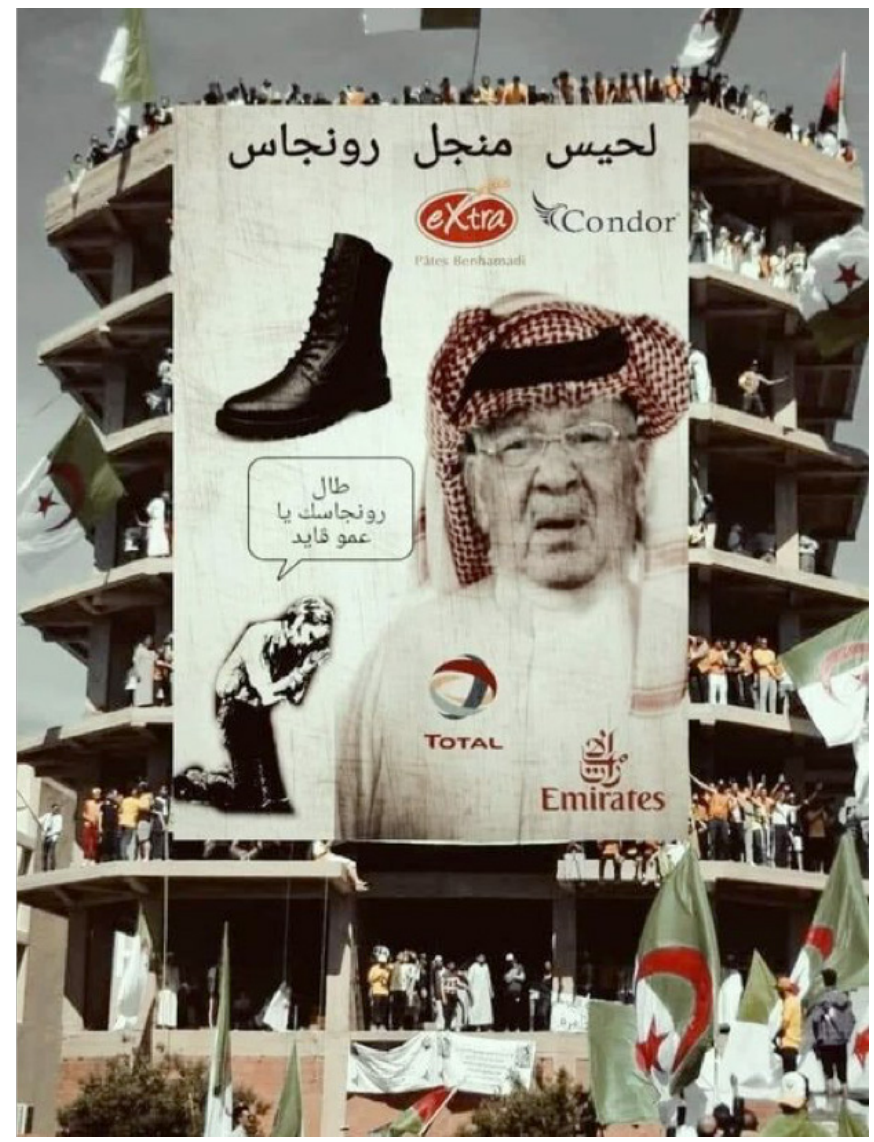

Tifo o despliegue escenificado de una pancarta gigante en la ciudad de Bordj Bou Arreridj, publicado por Smail Naravas vía Twitter, 02/06/2019

(https://twitter.com/Smail_Naravas/status/1135211359220711425?s=03) 
REFERENCIAS BIBLIOGRÁFICAS

Aichoun, Abdelghani. (20I9). «Conférence nationale de la société civile le 15 juin : Cap sur la transition ». El Watan. Argel. Disponible en: https://www.elwatan.com/a-la-une/conference-nationale-de-lasociete-civile-le-I5-juin-cap-sur-la-transition-09-06-2019 [Consultado el 20/06/2019].

Babouche, Yacine. (2019). « La Russie apporte son soutien au pouvoir algérien, met en garde les autres pays ». Tout sur l'Algérie. Argel. Disponible en: https://www.tsa-algerie.com/la-russie-apporte-son-soutienau-pouvoir-algerien-met-en-garde-les-autres-pays/ [Consultado el 2I/O6/2019].

Bustos García de Castro, Rafael. (2004). El cambio politico en Argelia (1988-1992). Análisis sistémico de una transición discordante. Tesis doctoral. Universidad Complutense de Madrid. Petschen, Santiago (dir.), Madrid.

Ghilès, Francis. (20I9). «Une Algérie debout et fière ». El Watan. Argel. Disponible en: https://algeria-watch.org/?p=71337 [Consultado el 20/06/2019].

Le-Monde (2019). « Algérie : Macron appelle à « une transition d'une durée raisonnable » après le renoncement de Bouteflika ». Le Monde. $\mathrm{Pa}-$ rís. Disponible en: https://www.lemonde.fr/afrique/article/2019/o3/ı2/ algerie-macron-appelle-a-une-transition-d-une-duree-raisonnableapres-le-renoncement-de-bouteflika_543475o_3212.html [Consultado el 25/06/2019].

RFI (20I9). «Algérie : 7 partis d'opposition se fédèrent pour sortir de l'impasse politique ». Radio France International. Paris. Disponible en: http://www.rfi.fr/afrique/20190620-algerie-7-partis-opposition-federent-sortir-impasse-politique [Consultado el 25/o6/2019]. 



\title{
LE MOUVEMENT POPULAIRE EN ALGÉRIE : VERS UNE RUPTURE SYSTÉMIQUE ?
}

SUR LES RACINES SOCIO-HISTORIQUES DE LA CRISE ALGÉRIENNE.

\author{
Adel Abderrezak \\ Enseignant-Chercheur - Ex Porte-parole du CNES (Syndicat des universitaires) \\ Article dédié à mon ami et compagnon de lutte, IDIR Achour dirigeant syndicaliste, \\ militant de gauche et une des figures actives du mouvement populaire, \\ décédé le 4 Avril 2019 à Bougie(Algérie).
}

\begin{abstract}
Resumen
El propósito de este artículo no es hacer relación del reciente movimiento popular acontecido en Argelia, ni hacer una cronología de hechos. Tenemos que recontextualizar históricamente este sistema de poder en su dimensión política y económica para poder comprender cómo se puso fin al ciclo de Bouteflika.
\end{abstract}

Palabras clave: Movimiento popular, sistema, poder, economía, política.

\section{Résumé}

Le but de cet article n'est pas de relater le récent mouvement populaire qui s'est déroulé en Algérie, ni de faire une chronologie des événements. Historiquement, nous devons recontextualiser ce système de pouvoir dans sa dimension politique et économique afin de comprendre la fin du cycle de Bouteflika.

Mots clés : Mouvement populaire, système, pouvoir, économie, politique.

\section{INTRODUCTION}

Un processus d'une rare singularité se déroule en Algérie, celui d'une «protesta» populaire aux allures morales, civiques et fraternelles. Dans toutes les villes du pays, sans exception, des manifestations d'algériens continuent à se dérouler le vendredi après-midi, un jour de week-end et religieux par excellence dans les habitudes des pays musulmans y compris l'Algérie. La surprise est aussi grande que l'événement lui-même. Un mouvement d'une grande ampleur, mobilisant toutes les couches et classes sociales du pays, dont les acteurs premiers sont les jeunes où les moins de 30 ans représentent $54 \%$ d'une population qui compte 42,2 millions d'habitants soit 22,7 millions et dont presque la moitié est féminine (Document ONS-juillet 2018). 
Cette protesta renvoie à une colère profonde du peuple algérien confronté à un régime politique caractérisé par l'autoritarisme et la prédation des ressources financières et du foncier algérien. En externalisant l'économie algérienne par des politiques publiques basées sur les consignes du FMI et les exigences d'une mondialisation libérale portée par les marchés financiers, l'UE et les Etats-Unis, L'économie algérienne s'est fragilisée et a occulté la demande sociale formulée en termes d'emplois (un chômage structurel et de masse), de logements (malgré les fameux deux millions de logements en construction) et de loisirs (l'islamisation a amplifié les interdits et les libertés culturelles et artistiques enterrées!).

La population algérienne, en particulier sa jeunesse et ses classes travailleuses fragilisées par cette libéralisation économique, aspire à une nouvelle ère. Les slogans formulés, l'auto-organisation de ce mouvement de contestation, son ampleur et sa fraternité conjugués à un pacifisme exemplaire et une présence croissante des femmes traduisent cette détermination collective de "la rue " le vendredi à une rupture radicale avec ce système au pouvoir. Le slogan le plus visible et le plus présent dans les manifestations est « système dégage ». Ca veut tout dire!

\section{LA PRIVATISATION HISTORIQUE DE L'ETAT}

Historiquement, l'Etat a précédé le capital en Algérie. Colonisé pendant I30 ans par la France, L'Algérie a conquis son indépendance politique en juillet 1962 et l'Etat-nation post-indépendant a été le creuset de toutes les espérances d'une population brimée et surexploitée par une colonisation violente et un capitalisme colonial sauvage pendant $\mathrm{I} 3 \mathrm{O}$ ans. Donc, occuper l'Etat-Nation a été au centre de tous les enjeux et de tous les rapports de pouvoir entre la population et la classe dirigeante naissante et au sein même de la classe dirigeante fractionnée, divisée et politiquement désarmée, dans les premières années de l'indépendance (Mohamed Harbi : Mirages et réalités. I980).

L'indépendance politique pensée comme le point de départ à une émancipation sociale a provoqué une dynamique autogestionnaire dans les latifundias coloniales abandonnées par les colons français où les ouvriers agricoles ont pris leur destin en main et provoquer une socialisation des moyens de production aussi bien dans l'agriculture coloniale que dans 
les manufactures et commerces appartenant aux colons (Monique Laks : Autogestion ouvrière et pouvoir politique en Algérie. 1970).

L'autogestion a été un processus d'occupation des biens vacants spontané, indépendamment de l'Etat et de l'élite nationaliste dirigeante a débouché sur l'auto-organisation des ouvriers en particulier dans le secteur agricole. Des comités de gestions ouvriers sont nés et ont tenté de se coordonner à l'échelle nationale débouchant sur le fameux congrès de 1964 de l'autogestion. Ce rappel permet de comprendre que pour les algériens, l'indépendance devait porter un contenu social et non pas se réduire à une dynamique nationaliste du pouvoir (Gérard Chaliand : L'Algérie est elle socialiste? 1964).

C'est ce contenu social, détaché des rapports de pouvoir, qui a été le point focal de la crise algérienne de 1962 à aujourd'hui ! Il est reposé clairement aujourd'hui par ce mouvement populaire qui exige une rupture du système, un « dégagisme » qui traduit une volonté forte d'en finir avec la façon dont l'Algérie a été gérée depuis l'indépendance. D'où ce sentiment d'analogie entre la ferveur populaire de l'indépendance de juillet 1962 et celle du mouvement populaire entamé le 22 février 2019.

Ce contenu social, de classe diront nous dans la conceptualisation marxiste, n'a été occulté qu'à la faveur d'une désappropriation du politique des algériens par lélite dirigeante qui, dés l'indépendance a occupé l'Etat-nation pour en faire un outil de promotion sociale et politique. Létatisation de la société prend forme et emprunte des chemins classiques : coup d'Etat en 1965, militarisation du pouvoir par l'armée des frontières, structuration clanique de l'Etat par le clan d'Oudjda avec les dégâts collatéraux connus : répression de l'opposition au pronunciamiento, restrictions totale des libertés individuelles et politiques et opacité du pouvoir. L'autogestion est enterrée, l'émancipation économique et sociale reportée et la marginalisation politique consacrée. Un système politique autoritaire se met en place, celui la même que les algériens de 20I9, c'est-à-dire presque 60 ans après, ont décidé de rejeter. Plus d'un demi-siècle d'une Algérie dirigée en dehors de la souveraineté populaire ou plus précisément contre.

Ce système de pouvoir est basé d'abord sur une densification institutionnelle permanente qui a permis l'éclosion d'une bureaucratie politi- 
quement docile au noyau dur de l'Etat. Cette bureaucratie est socialement pro-capitaliste au sens où elle capitalise son statut politico-administratif pour accumuler des richesses à travers les prébendes de l'Etat. Domicilié dans les appareils administratifs, technocratiques et surtout militaires, cette bureaucratie gouvernante dans les appareils d'Etat prend la forme sociale d'une bureaucratie bourgeoise et la forme politique d'une bureaucratie autoritaire.

Ce processus n'a été possible que par une logique putschiste qui permettait une militarisation des appareils d'Etat et une subordination de la société à l'Etat. Le noyau dur de l'Etat, de I962 jusqu'à 20I9, a été et reste le noyau d'Oudjda cristallisée dans l'armée des frontières au sein de l'Etat-major de l'ALN (armée de libération nationale) au Maroc, c'est-à-dire une conception clanique du pouvoir centrée sur le militaire, actionnant en permanence l'allégeance de la population, toutes classes confondues, aux appareils d'Etat et ceux qui les personnalisent et se nourrissant d'une culture autoritaire et anti-démocratique.

C'est ainsi que s'est concrétisé sur plusieurs décennies ce processus de privatisation de l'Etat et de ses appareils politiques par les régimes politiques successifs qui étaient quasiment tous, en dehors de la parenthèse de Boudiaf (président assassiné en juin 92), dans la filiation historique du groupe d'Oudjda et de l'armée (Houari Boumedienne, Chadli Bendjedid, Lamine Zeroual, Abdelaziz Bouteflika). Bouteflika a rendu plus systémique que jamais cette culture clanique dans les appareils de l'Etat et les rapports d'allégeance qui ont anesthésié la société pendant 20 ans (I999-2019) et transformé l'Etat et toutes les institutions publiques en une « affaire privée ».

Le pouvoir politique se confond avec l'Etat et se cristallise autour d'une culture anti-démocratique, d'une dépolitisation continue de la société, d'une reproduction délibérée des archaïsmes sociaux et culturels enveloppée dans une religiosité très conservatrice (code de la famille en I984) et d'un nationalisme désuet qui glorifie de façon indécente le patriotisme anti-colonial. Mais le puzzle supposé solide et invariant connaitra sa première grande fissure en octobre 88 , puis en 200 I et celle que nous vivons aujourd'hui, singulière et nécessairement plus systémique, entamé le 22 février 2019 . 
C'est la que se retrouve le sens profond du mouvement populaire de février 20I9 à aujourd'hui : le rejet radical d'un système immoral à travers le slogan le plus crié dans les manifestations : « Système Dégage »...un « dégagisme » systémique!

\section{L'ÉCONOMIE ENTRE CAPITALISME D'ETAT ET AUTORITARISME}

Au début, ce système politique de pouvoir s'appuyait sur le plan économique et social sur une économie publique monopoliste et une politique pro-sociale envers la population donnant un trait socialisant au modèle algérien, un profil « anti-impérialiste » et une dimension populiste le rapprochant des régimes nassérien ou latino-américain des années 70. La raison est bien simple.

Pour se subordonner une société politisée qui se projetait déjà dans un devenir de progrès social qui répond aux attentes sociales d'une population pauvre, dépossédée et martyrisée par la colonisation, le régime politique post-indépendant recadré par le coup d'Etat de juin 1965, avait besoin de traduire ces attentes sociales dans des politiques publiques et d'alimenter cette articulation entre autoritarisme et politiques sociales par l'idéologie socialisante. D’où ce « socialisme spécifique " prôné dés l'indépendance et traduit dans un système économique centralisé et monopoliste à partir de la fin des années 60 où une économie mixte combinant planification et règles marchandes se met en place autour de projets industrialistes et un début de mise au travail des algériens. C'est le socle économique de ce qu'on appelle le « capitalisme d'Etat algérien ».

Industries industrialisantes et politiques sociales ont été les deux béquilles d'un capitalisme d'Etat construit, depuis les années 7o, autour d'un mode politique autoritaire et personnalisé autour du président, d'une centralisation des ressources financières et du budget d'Etat et de leur gestion aux mains d'une bureaucratie politique concentrant tous les pouvoirs et d'une redistribution populiste des revenus vers une population ouvrière ou lumpénisée entretenant l'idée d'un Etat social ou d'un Welfare-State algérien (Marc Raffinot et Pierre Jacquemot : le capitalisme d'Etat Algérien, 1977). Evidemment, l'opacité et la gouvernance anti-démocratique ont permis la corruption généralisée au sein des appareils d'Etat. Les projets industrialistes gérés de façon technocratique et tournés sur les 
marchés extérieurs dans une phase de financiarisation du capitalisme se sont fourvoyés dans l'endettement structurel et le gaspillage délibéré des ressources financières publiques.

Au fond, comment expliciter ce capitalisme d'Etat algérien ? Le capitalisme D'Adam Smith et Ricardo renvoie à cette économie de marché considérée comme le cours naturel du système capitaliste. Il se fonde sur la séparation du politique de l'économique et sur l'éloignement de l'Etat de l'espace économique du capital. Cette représentation intellectuelle et idéologique du capitalisme correspond rarement à la réalité, y compris dans les pays de l'OCDE car l'interventionnisme étatique est partout et prend des formes différenciées selon l'histoire de chaque pays.

En Algérie, la faiblesse historique d'une bourgeoisie locale, occultée par la colonisation de peuplement et un capitalisme colonial jacobin, sera, après l'indépendance trop naine pour porter un projet économique fondé sur le capital et les lois du marché. Le national-populisme du régime politique de Boumedienne va substituer à la défaillance " génétique » de la bourgeoisie algérienne, une économie publique relié dans ses échanges aux règles du marché international mais doté de tous les monopoles de production, de commercialisation et d'importations. Les ressources financières proviendront plus d'une rente pétrolière captées dans le marché mondial des hydrocarbures que des résultats fructueux de l'industrialisation nationale.

En fait, une sorte de « capitalisme collectif » cristallisé dans l'Etat se réalise à travers un secteur public monopoliste qui sera le terrain privilégié, non pas d'une accumulation étatique, mais d'une accumulation privée de capital-argent transformée en rentes commerciales ou immobilières et rapidement après, en manufactures et industries de transformations ou d'extractions grâce aux marchés publics et les crédits faramineux accordés par les banques commerciales publiques au secteur privé.

Tout cela pour expliquer d'abord que le capitalisme d'Etat algérien est une bifurcation, pour des raisons d'histoire, du parcours naturel du capitalisme de marché et aussi pour faire ressortir combien les modes autoritaires de gouvernance politique était organiquement lié aux modes d'accumulation et de captation des ressources financières de l'Etat. Ce qui signifie que l'enrichissement d'une bourgeoisie algérienne pas- 
sait obligatoirement par l'allégeance politique et par un jeu d'intérêts financiers et économiques à la bureaucratie gouvernante qui elle aussi œuvrait, à l'intérieur d'un Etat qu'elle a privatisé, à son enrichissement et sa valorisation sociale.

On peut comprendre, à partir de là, le caractère historiquement étatiste de l'économie algérien, le caractère rentier et prédateur de la bureaucratie politique gouvernante de l'Etat et le caractère capitaliste par « effraction » d'un secteur privé historiquement nain et politiquement dépendant. Après les politiques de libéralisation, d'ajustement structurel et de privatisation de l'économie publique depuis I990, suite au rééchelonnement conditionnel de la dette algérienne et aux injonctions du FMI, la connexion entre bureaucratie militaro-politique dirigeante et une bourgeoisie privée se déployant dans le flanc des marchés publics et de la rente étatique, va s'approfondir permettant à la bureaucratie proto-capitaliste de se libérer du complexe de l'argent et à la bourgeoisie privée de pénétrer l'Etat et de construire des relais directs dans le pouvoir politique.

De ce point de vue, le régime Bouteflika est celui qui a été le plus loin dans ce processus permettant à son clan de s'enrichir très vite et de capter la rente financière de l'Etat en y associant la frange " oligarque » de la bourgeoisie et à cette dernière d'entrer en force dans les appareils de l'Etat par une sorte de système de vénalité des offices et dans les institutions de représentation nationales et locales (APN, Sénat, APW, APC). Cette conjonction d'intérêts a donné forme à un bloc social dominant où les intérêts de classes d'une bourgeoisie compradore, qui est né de la démonopolisation de l'économie publique, cohabitent et s'articulent avec ceux d'une classe militaro-politique qui fait du « capital politique »le point nodal d'une accumulation capitaliste privée.

La particularité de ce capitalisme d'Etat « libéralisé » est de s'appuyer sur une gouvernance impérativement autoritaire et restrictive des libertés et d'un contrôle jacobin et opaque des ressources et richesses publiques faisant du budget de l'Etat, des banques commerciales publiques et du contrôle douanier les garants d'une corruptibilité systémique et d'un transfert illimité des deniers de l'Etat au bloc social dominant. De ce point de vue, aussi bien la corruption que la prédation financière de et dans l'Etat ne sont pas une dérive morale liée à une gouvernance bu- 
reaucratique, comme le pense l'UE, les Etats-Unis ou même les ONG, mais les formes singulières d'une accumulation bourgeoise-capitaliste dont les flux se destinent plus au marché mondial qu'à une introversion du développement économique.

3. LES RESSORTS ÉCONOMIQUES DE LA CRISE ALGÉRIENNE ET SON PENDANT POLITIQUE

Ainsi, les ressorts de la crise systémique que vit l'Algérie aujourd'hui, pouvoir et société, sont dans la nature rentière du capitalisme d'Etat et la privatisation clanique de l'Etat et ses différents appareils ainsi que dans un système d'allégeance ou de subordination de couches sociales compensées par une redistribution minime de la rente ou prébendes d'aliénation! Ce système résiste et impacte sur les tentations conflictuelles dans la société tant que l'aisance financière est garantie par le prix élevé du pétrole.

Il rentre dans un cycle de crises cumulatives (depuis les années 80 en Algérie) quand la rente pétrolière s'effrite par l'effondrement du prix du baril de pétrole dans les marchés internationaux. A ce moment là, les différences sociales et de classe, les injustices sociales, les atteintes aux libertés individuelles, syndicales ou politiques deviennent inacceptables. Le processus d'enrichissement du clan dominant le pouvoir d'Etat et ses relais dans l'économie privée sont apparentés à un pillage des ressources de l'Etat et de la société.

Ce système s'est déjà auto-bloqué dés la fin des années 70 et la mort inattendue de son premier concepteur et leader du clan d'Oudjda, Houari Boumediene, le président algérien des années 70, va accélérer sa crise. Une réforme du système s'imposait au niveau politique et au niveau des politiques publiques mais l'élite dirigeante restait dans le format d'un microcosme bureaucratique fermé sur lui-même s'enrichissant de corruption et de privatisation de biens publics et s'exprimant par les non-dits dans les mess des officiers de l'armée. Seul comptait les ambitions capitalistes qui allaient prendre forme plus rapidement au sein de la bureaucratie bourgeoise au pouvoir à la faveur d'une dénationalisation progressive de l'économie algérienne, une sorte d'infitah (ouverture) rampant à l'égyptienne. Entre I978 et I988, le président Chadli va déplanifier l'économie 
publique, introduire les règles marchandes dans les entreprises d'Etat et libéraliser le commerce intérieur.

Octobre 88 va être le révélateur d'une véritable crise systémique et bouleverser le cours bureaucratique de l'Algérie. Le divorce entre le pouvoir et la société se manifestera par l'explosion sociale d'octobre 88, une intifada populaire où la jeunesse algérienne entre pour la première fois dans le cours de l'histoire (Sid Ahmed Semiane, Octobre : ils parlent, I998) en rejetant violement tous les symboles du système. La réponse paniquée du pouvoir et d'une bourgeoisie rentière inquiète de son devenir, sera une répression sans précédent dans l'histoire algérienne post-indépendante menée par l'armée algérienne, qui entame un nouveau cycle de remilitarisation du pouvoir, des appareils d'Etat et de la société.

La normalisation politique, après la répression d'octobre 88 (plus de 500 morts), passera par le détournement de la « subversion » populaire par la mise en avant du courant islamiste dont la radicalité emprunte le détour d'un projet de société rétrograde mixée à une économie libérale. Le Front islamique du Salut(FIS) saura capter la radicalité sociale des jeunes par un populisme religieux aussi radical qui le met dans la posture de la formulation d'un ordre moral qui cible intelligentsia et élite politique et syndicale démocratique ou de gauche. Le rapport de force que le FIS a installé, s'appuyant sur son aura populaire et électorale le met dans une confrontation frontale avec un pouvoir politico-militaire inquiet de ses débordements. Le résultat est connu, c'est la décennie noire 1990-2000: lutte anti-terroriste, gestion sécuritaire de la société et restrictions totales des libertés publiques et individuelles (Brahim Hadj Slimane : les années noires du journalisme en Algérie, 20Io).

Une décennie qui va décimer aussi bien l'élite intellectuelle que militante et le petit peuple dans des pogrooms collectifs (village Bentalha à I5 $\mathrm{km}$ de la capitale, plus de 400 morts) ou l'exil sur fond d'autoritarisme, de libéralisation économique et de captation privée de rente. Fin des années 9o, l'Algérie aborde une nouvelle étape avec une société abimée, avec une jeunesse qui aspirait à exister, un capitalisme d'Etat qui avait besoin de répit et une mondialisation capitaliste qui attendait un retour d'investissement dans un pays déstabilisé. 
C'est dans ce contexte que Bouteflika est venu et a construit son système de pouvoir clanique, prolongement personnalisé du clan d'Oujda, en intégrant l'aspiration sociale d'un retour à la paix et la nécessité de reconnecter l'économie algérienne avec ses richesses pétrolières et minières aux impératifs du néo-libéralisme qui dominait le cours de la mondialisation. Un système de pouvoir qui produit ses propres contradictions et qui peuvent l'amener à l'implosion.

4. UNE RÉVOLUTION POPULAIRE EN COURS OU UN PRINTEMPS ÉPHÉMÈRE ? Le cours actuel de la crise politique et l'avènement d'un mouvement populaire de protestation depuis le 22 février 2019 renvoie à un système historiquement dégénératif qui est devenu un obstacle fondamental à une construction politique et sociétale en phase avec une population très jeune, instruite et sans projet de vie où les besoins sociaux sont aussi importants qu'un vécu existentiel et culturel connecté aux ouvertures d'un monde internationalisé.

Le divorce entre la société et ses gouvernants (le clan Bouteflika) a pris une dimension de « rejet collectif et viscéral », qui n'avait pas trouvé son prolongement, avant ce mouvement, dans une réaction collective et organisée malgré la permanence de luttes sectorielles ou émeutières et sans impact majeur sur les rapports de forces entre le pouvoir et la société.

Le déficit de légitimité politique de la classe politique s'est conjugué à une dépolitisation objectivement nourrie par les restrictions des libertés et une mondialisation qui fétichise l'argent et la technologie. La jeunesse algérienne n'y as pas échappé. (Notre article à L'hebdo militant du NPA, mars 20I9).

Un régime politique vieilli, totalement discrédité par son OPA sur les ressources pétrolières et se reproduisant sur une toile d'allégeance incrustée dans les sphères sociales, institutionnelles et politiques, ne pouvais ne pas provoquer l'implosion d'une colère populaire. Le facteur déclencheur aura été la présentation d'un président-candidat vieilli, malade et totalement handicapé pour un cinquième mandat en février 2019 dans la perspective d'élections présidentielles prévues le i8 avril 20I9. Un acte immoral perçu par la population comme une offense pour la nation, 
son histoire et son drapeau. Et l'histoire algérienne a pris un nouveau cours...!

Comment caractériser un mouvement de contestation populaire si massif, si impressionnant par son civisme, ses expressions libertaires et son sens de la lucidité ? Fondamentalement, ce mouvement n'est pas le produit d'une politisation de la société suite à des événements cumulatifs liés à un processus de conquête du pouvoir ou à une confrontation de jeu d'intérêts contradictoires exprimés politiquement à travers les partis.

Ce mouvement n'est pas le résultat d'une stratégie de l'opposition, toutes tendances confondues, car cette dernière, au-delà d'une existence essentiellement institutionnelle et formelle, ne s'est pas construite comme un contrepoids au système mais comme un élément organique de celui-ci. Les partis de la majorité présidentielle sont des appareils administratifs pour la promotion du clan présidentiel. Les partis démocrates se contentent d'exister en s'accommandant des normes établies par le clan politique dominant. Le Parti des travailleurs (trotskiste-courant lambertiste) est porteur d'un verbe de gauche mais s'est déconnecté des traditions et repères du mouvement ouvrier. Son arrestation, bien qu'arbitraire, ces derniers jours confirme ses liens avec «l'Etat profond » (formule utilisée pour désigner les décideurs réels mais rarement visibles ni identifiés). Un microcosme de « mini-organisations » s'attache à exister idéologiquement sans identité réelle. Une singularité, Le Parti socialiste des travailleurs (PST), présent activement dans les mouvements sociaux et les luttes syndicales, qui tente d'impacter sur le débat politique de façon significative ! Néanmoins, la crise du politique est là et elle concerne tout le monde.

Cette délégitimation du politique, dans la représentation sociale, explique le rôle presque directif de ce mouvement populaire par les réseaux sociaux. C'est aussi un considérant nouveau pour le champ politique moderne, en particulier dans les pays à faible traditions démocratiques comme les pays du MENA. Après l'Egypte, l'Algérie construit son propre printemps par facebook et les réseaux sociaux.

Les NTIC ne sont plus un outil de la technologisation du capital via la mondialisation mais aussi un outil critique pour les mouvements sociaux. Leur utilisation libre et permettant l'expression sans limites de tous ceux qui l'utilisent en a fait le fil conducteur de ce mouvement et 
son coach programmatique. C'est aussi, parce que les règles classiques du politique nétaient pas imposées sur Facebook que l'humour et la dérision ont marqué l'expression de ce mouvement et participer à en faire un mouvement fait de fraternité et d'inventivité. De ce point de vue la jeunesse a surpris par sa vivacité.

Ce mouvement a la particularité d'être non-religieux pour ne pas dire laïc (assimilé à athée dans les pays musulmans) malgré le poids du religieux dans le champ politique et son histoire tourmentée en Algérie. Le contexte n'est pas le même. Les années 9o, période d'éclosion de l'islamisme politique) a enfanté la décennie noire 90-2000 marqué par ce qu'on appelle « la guerre civile » où la militarisation de l'islamisme a conduit à un face à face Pouvoir-FIS dont les conséquences tragiques sur la société civile, l'intelligentsia et les femmes ont été tragiques.

La faible religiosité de ce mouvement renvoi à la défaite de l'islamisme politique et à la reconversion de l'essentiel de son élite dans les espaces de pouvoir et de Business encadrés par le pouvoir politique. La génération-jeune, substance sociologique de ce mouvement, née dans les années 90, a vécu les traumas et aspirent à un vécu existentiel fait de modernité, de mixité et de réalisme social. Voilà pourquoi ce mouvement ne peut pas être religieux ni islamiste, malgré le retour d'un activisme islamiste discret dans les manifestations.

La force de ce mouvement populaire qui fait de la fraternité et du civisme des armes privilégiées pour bousculer les rapports de force est de s'installer dans la durée avec une détermination sans faille. D'où la difficulté du pouvoir, recentré sur le chef d'Etat-major de l'armée, de sortir de cette crise par un scénario crédible. La faiblesse de ce mouvement populaire est liée à sa dépolitisation, c'est-à-dire à sa difficulté de percevoir les vrais enjeux (moins visibles), de contourner les tentatives de manipulation ou de normalisation et formuler politiquement la dimension programmatique de ce mouvement populaire.

Jusqu'à aujourd'hui, la pression populaire se joue autour des élections présidentielles fixées le o4 juillet dans le cadre d'une issue cadrée par la constitution actuelle et voulue par un chef d'Etat-major de l'armée s'imposant de force comme le vrai décideur de l'Algérie en crise. Une sorte de scénario à la Sissi (président égyptien) se met en place rejeté par les 
dernières manifestations populaires du vendredi. Le rejet populaire des élections présidentielles semble pousser Gaid Salah, le dirigeant de l'armée, à envisager un autre scénario d'urgence alors que dans la rue, l'idée de constituante semble faire son chemin comme la seule issue pour une rupture sérieuse avec le système politique algérien issu du dévoiement de l'indépendance algérienne depuis 1962.

\section{BIBLIOGRAPHIE}

Abderrezak, Adel. "Libéralisation économique et privatisations ", Confluences Méditerranée, vol. 45, nº. 2, 2003, pp. 95-I05.

Abderrezak, Adel. "Algérie, une dynamique de crise pré-révolutionnaire », $N P A$, I4 mars 2019, Paris, lien : https://npa2009.org/actualite/ international/algerie-une-dynamique-de-crise-pre-revolutionnaire

Abderrezak, Adel. « L'Espérance algérienne en mouvement! », Relations $\mathrm{n}^{\circ} 803$ (juillet-août 20I9), Quebec, lien : https://cjf.qc.ca/revuerelations/

Chaliand, Gérard. L'Algérie est elle socialiste? , éd. François Maspéro, I964.

Hadj Slimane, Brahim. Les années noires du journalisme en Algérie, ed. du Cygne, Paris, 2010 (Un chapitre nous est consacré, p. 2I).

Harbi, Mohamed. Le FLN, mirages et réalités, des origines à la prise de pouvoir (1945-I962), éd. Jeune afrique, Paris, I980.

Kitouni, Hosni. Le Désordre Colonial, L'Algérie à l'épreuve de la colonisation de peuplement, Casbah éditions, Alger, 2018.

Koulytchysky, Serge. L'autogestion, l'homme et l'Etat, éd. Mouton, Hollande, I974.

Laks, Monique. Autogestion ouvrière et pouvoir politique en Algérie (19621965), éd. EDI, Paris, I970.

Nezzar, Khaled, et Sid Ahmed Semiane. Octobre : ils parlent, éd. Le Matin, Alger, 1998.

Raffinot, Marc et Pierre Jacquemot. Le capitalisme d'Etat Algérien, éd. François Maspéro, Paris, I977. 



\title{
LE REGARD DE DIB ET CAMUS SUR LE PAYSAGE ALGÉRIEN
}

\author{
BrigitTe Leguen \\ $U N E D$
}

\section{Resumen}

Mohamed Dib y Albert Camus ambos nacieron en Argelia rodeados por el mismo paisaje. En este artículo analizaremos cómo cada uno percibe el espacio y sus significados.

Palabras clave: literatura, espacio, paisaje.

\section{Résumé}

Mohammed Dib et Albert Camus sont nés tous deux en Algérie entourés du même paysage. Dans cet article nous analyserons comment chacun perçoit l'espace et ses significations.

Mots clés : littérature, espace, paysage.

Beaucoup de choses nous séparent; d'autres nous unissent. Le paysage est un de ces éléments qui donne aux hommes et surtout aux artistes, l'occasion du partage par la contemplation de certains espaces privilégiés avec lesquels le dialogue est possible.

Cette contemplation met en œuvre des attitudes et des aptitudes basées sur une expérience visuelle, cognitive, littéraire, poétique qui sera l'occasion d'explorer et de comprendre qui l'on est, d'où l'on vient. Car le paysage a beaucoup à voir aussi avec la mémoire, avec la nostalgie. Il est enfin le lieu de l'identité. L'identité réelle, originelle, l'identité fabriquée.

L'œuvre de Mohammed Dib cherche à nommer la relation entre le paysage et son peuple, entre le paysage et lui-même.

"Au commencement est le paysage » Dira Dib paraphrasant la Genèse.

Dans sa poésie, dans ses romans, dans ses commentaires autour des photos qu'il a prises dans les années 40 à Tlemcen, le paysage se définit comme un phénomène de l'existence, une expérience fondatrice qui va de l'extérieur à l'intérieur, de la superficie aux origines, à partir de cette ville de Tlemcen, Le Pays des sources, le cadre de son enfance, là où il 
a vécu avec sa famille, ses frères et sœurs. Les photographies prises en I946 et commentées en I994 dans le livre Tlemcen ou les lieux de l'écriture et dans L'Arbre à dires de I998 s'échafaudent sur un double sentiment d'appartenance, algérienne par la culture et française par la colonisation de la langue.

L'écart temporel entre la prise d'image photographique et le moment des commentaires est un entretemps bouleversé par l'Histoire de l'Algérie, la guerre, l'indépendance, l'expulsion de Mohammed Dib, son établissement en France pour une situation d'exil permanente.

Plus rien n'est semblable désormais, ni pour lui ni pour tous les algériens.

Pourtant le travail de déconstruction des stéréotypes qu'entreprend Dib est bien antérieur à la décolonisation. Ses premiers textes, dès les années 50, La Grande Maison, L'incendie, Le Métier à tisser répondent au besoin de donner à son pays, à son histoire, une forme littéraire qui propose sa vision de l'Algérie de l'intérieur à partir de son expérience personnelle, qui représente le monde arabe et kabyle où il est né en contraste avec celle des écrivains algériens français comme Emmanuel Roblés, Albert Camus ou Jules Roy plus marqués par la perspective eurocentrée.

Dans de nombreuses interviews, Dib prend ses distances avec les préjugés coloniaux tout en essayant d'établir le contact avec l'Autre, attentif à la vérité schizophrène qui se dédouble et varie selon que l'on soit dominé ou dominant.

L'acte d'écrire lui permet de rejeter l'image déformée du colonisé et de donner à voir ce qui l'amène à la révolte.

Dans ce contexte difficile, où les expériences s'échelonnent selon la place qu'on occupe, selon les expériences qu'on endure, selon les pré/jugés systématiques, la relation d'Albert camus à ce même espace s'avère fragile et parfois ambigüe.

Camus dans son discours de Suède revendique son appartenance à une génération d'écrivains d'Algérie. Au moment de sa mort prématurée, Dib coordonne un hommage à son ami «Camus l'Algérien » et beaucoup d'aspects de leur enfance et de leur jeunesse les rapprochent, même si d'autres les séparent indéfectiblement : Une enfance pauvre, un père 
absent, l'engagement politique et les premiers combats, la littérature, et la contemplation amoureuse de leur paysage.

Dans la réédition de L'Envers et l'Endroit, en I958, Camus écrit :

"Chaque artiste garde ainsi, au fond de lui, une source unique qui alimente pendant sa vie ce qu'il est et ce qu'il dit [...] Pour moi, je sais que ma source est dans L'Envers et l'endroit, dans ce monde de pauvreté et de lumière où j'ai longtemps vécu ».

Arrêtons-nous aussi à cette magnifique exergue de Médée qu'il citera au début de Retour à Tipasa (1954) : «Tu as navigué d'une âme furieuse loin de la demeure paternelle, franchissant les doubles rochers de la mer, et tu habites une terre étrangère ».

Dans son texte La mer au plus près, il décrit ainsi son exil et son paysage :

«J'ai grandi dans la mer et la pauvreté m’a été fabuleuse, puis j’ai perdu la mer, tous les luxes alors mont paru gris, la misère intolérable. Depuis, j'attends. J'attends les navires du retour, la maison des eaux, le jour limpide. Je patiente, je suis poli de toutes mes forces. On me voit passer dans les belles rues savantes, $\mathrm{j}$ 'admire les paysages, j'applaudis comme tout le monde, je donne la main. Ce n'est pas moi qui parle. ».

L'exil dibien est plus déchirant, c'est un cri pathétique qui souligne l'absence forcée de celui qu'on a chassé de son paradis. Il dit dans Les terrasses d'Orsol: « Qu'on me rende ma ville, que je puisse rencontrer des visages qui me parlent, des visages dont je puisse faire le tour, comme on fait chez nous pour le plaisir de la promenade le tour des remparts, comme on boit du thé à l'ombre des platanes, comme on court au devant de la mer, affronte de la poitrine cette mer miterreine nôtre, vacillant sous le point du soleil » (pp.85-86). Il aura le lyrisme du poète et la précision du topographe qui va de la Médresse à la maison du dhikr en passant par les Jardins de l'Éternité.

Ce parcours initiatique qui ne cessera jamais est une exploration incessante de l'écrivain au sein d'un monde organique qu'il réinvente à chaque livre :

«Ceux qui ont eu la curiosité de me lire pourront en témoigner. De l'un à l'autre de mes livres, des passerelles sont jetées, non d'une manière calculée 
mais comme la conséquence naturelle d'une manière de procéder, traverses qui relient chaque livre à un autre, nullement dans une succession logique, mais organique. Car ce n'est pas une suite romanesque, ou poétique, que je me suis efforcé de mettre sur pied, j'ai été tenté au contraire par l'aventure que constitue une exploration tous azimuts » (L'Arbre à dires : 208).

Ce travail sur lui-même, cette exploration intérieure est toujours doublée du même procédé extérieur. Dans une interview intitulée «Mohammed Dib ou le regard intérieur " l'écrivain souligne l'importance pour lui de nommer en littérature les personnages et les lieux de ses livres :

"Avec La Grande Maison, avec L'Incendie, et Le Métier à tisser, le point de départ- j'ai dit que c'était un constat- c'était aussi un acte de foi. Il consistait en cela qu'il nommait ce qui n'avait pas encore été nommé, en littérature bien sûr. On n'avait pas encore vu dans les livres ces personnages qu'on trouve dans la trilogie. Ces personnages n'avaient pas d'existence littéraire. Les lieux non plus. Même s'il y avait eu précédemment des écrivains français ou algériens de souche française installés en Algérie, qui avaient écrit et situé des œuvres en Algérie, mais disons qu'il n'y avait pas cette intimité avec le paysage. Nos œuvres se sont trouvées, par la force des choses, davantage inscrites dans le paysage. Et dans ce paysage, même si certains de ses aspects ont déjà figuré dans des livres d'auteurs français, ce nétait pas dans le détail, dans l'intimité, dans la profondeur du paysage et surtout ce nétait pas dans la relation entre hommes, entre êtres humains et paysage. Or, c'est une relation fondamentale. C'est la relation qui est un des éléments de l'identité d'une personne ou d'un peuple. ».

Dans cette intervention, Dib utilise par deux fois le mot « intimité » mis en relation avec le paysage comme si l'intime ultime devait être lié à l'origine ou aux origines qui représentent le lien entre l'homme arabe et sa terre.

L'autre terre de l'écrivain c'est bien sûr sa langue. Le combat de Dib pour défendre son identité réelle avec une langue acquise à la force du poignet.

« [...] La langue française est à eux, elle leur appartient. Qu'importe, nous en avons chipé notre part et ils ne pourront plus nous l'enlever. Ils n'attendent pas moins que nous les en remercions.

Mais qui, des uns, devraient remercier les autres? Et si, parce que nous en mangeons aussi de ce gâteau, nous lui apportions quelque chose de 
plus, lui donnions un autre goût ? Un goût qu'ils ne lui connaissent pas. [...] cela irrite, cela dérange tout de même certains français de nous voir écrire dans leur langue. La preuve? A chacune de mes rencontres avec le public, il s'en trouve un qui me prend à partie et me somme de me justifier. Il m'est naturel d'écrire en français, que puis-je dire d'autre ? [...] Il faut se rendre à l'évidence. Nous ferons toujours partie de ces immigrés ou de ces bohémiens qui campent aux abords d'une ville et sont soupçonnés de voler les poules de l'autochtone $[. .$.$] je reste donc là à camper sur le$ terrain vague d'une langue».

L'amertume ironique de ce propos est une pierre sur le terrain vague dibien qui n'a jamais cessé de blessé mais qui ne l'a pas empêché de créer des liens avec des intellectuels d'Afrique du Nord. Pourtant, après de grandes tentatives de partage et la création de revues littéraires souvent éphémère comme Forge, Soleil, puis Terrasses et Simoun l'inévitable rupture aura lieu.

Dib traverse la période coloniale et sa décadence, la période de décolonisation et finalement l'indépendance, et à chaque pas, son œuvre est en dialogue intérieur/extérieur avec cette périphérie que représente la colonie par rapport à la métropole qui se veut et se dit le centre de toutes rencontres.

Les journées de Sidi Madani et les contacts avec Parain, Tortel, Guilloux, Cayrol (qui le mène aux éditions du Seuil) Camus, lui permettent, dans sa première étape, de commencer à publier ses romans et poèmes en France.

Il est le poète du bouleversant poème Sur la terre errante qui s'adresse à la terre algérienne, celui qui devra partir pour ne plus revenir en dépit des tentatives; mis à l'écart.

Le parcours de l'écrivain algérien Mohammed Dib se termine en 2003 dans l'accomplissement d'une œuvre dense, diverse et combattive.

Camus meurt accidentellement en I960 mais en 1994, la parution posthume de son roman autobiographique Le premier homme remet en scène l'écrivain à un moment où les violences se déchaînent dans son pays d'origine et conduisent à une réévaluation de l'Histoire nationale.

Assia Djebar dans son texte Ces voix qui m'assiègent (1999) revient sur Le premier homme et sur l'identité de Camus, auteur algérien : 
"Et je souris à celui qui, dans une des notes accompagnant le texte inachevé, remarquait à propos de son double : « Ce qu'ils n'aimaient pas en lui, c'était l'Algérien. » Justement, je souris à cet algérien -là [...] parce qu'écrivain, parce que femme et parce qu'Algérienne. »

Et S'adressant à ce Camus algérien, elle dira :

«Mon presque compatriote par la terre et l'espace d'enfance, plutôt que par l'histoire ».

Rendons hommage aux paysages, à la beauté des textes camusiens, ceux de L'Été et de Noces.

Paysages naturels de Tipasa et Djemila, paysages urbains de la ville d'Oran, dans le Petit Guide pour des villes sans passé.

Dib et Camus laissent en héritage dans leurs œuvres un regard et une écriture des paysages de l'Algérie qui fait d'eux ce que Camus appelaient des « frères de soleil ».

A titre de conclusion, rappelons les paroles de Jean Grenier dans son prologue aux «Inspirations Méditerranéennes » publiées en I939. Il y disait :

«Il existe pour chaque homme des lieux prédestinés au bonheur, des paysages où il peut s'épanouir er connaître, au-delà du simple plaisir de vivre, une joie qui ressemble à un ravissement, une de ces joies dont parle Flaubert : "J'ai entrevu quelquefois un état de l'Âme supérieur à la vie, pour qui la gloire ne serait rien, et le bonheur même, inutile ».

La Méditerranée peut inspirer un tel état de l'âme. Elle ne risque pas de jeter dans cette confusion de sentiments qui faisait voir aux Romantiques dans les paysages un aliment spirituel ou même une intuition du divin. Par les lignes et les formes qu'elle impose elle rend la vérité inséparable du bonheur ; l'ivresse même de la lumière n'y fait qu'exalter l'esprit de contemplation. » 


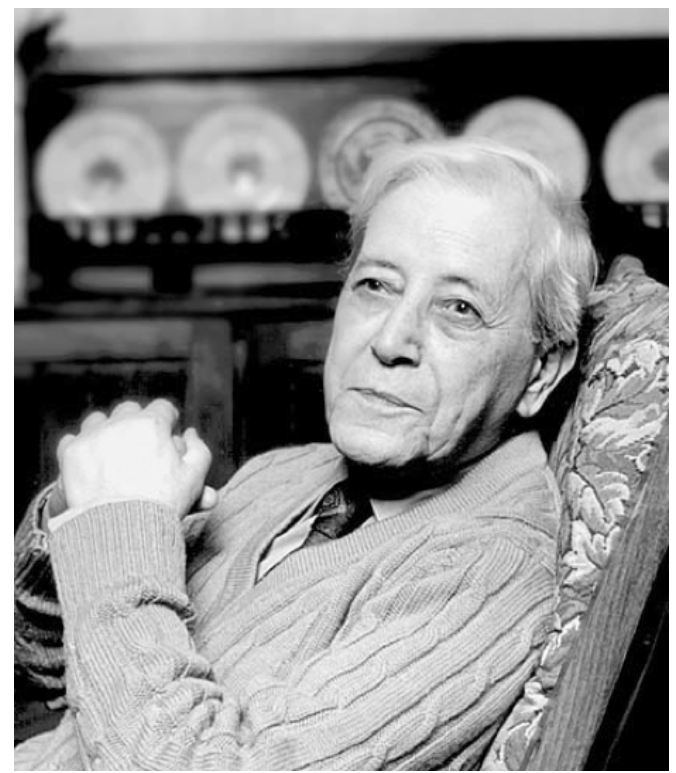

Mohamed Dib

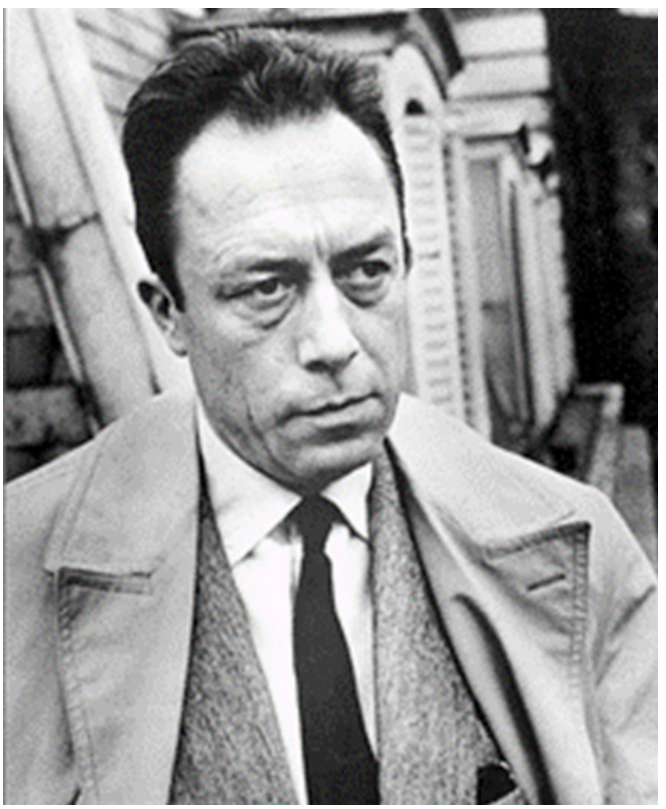

Albert Camus 


\section{BIBLIOGRAPHIE}

CAmus, Albert. L'Été, Paris, Gallimard, I954.

Camus, Albert. Le Premier Homme, Paris, Gallimard, 1994.

Camus, Albert. Noces, Paris, Gallimard, I950.

Camus, Albert. L'Envers et l'Endroit, Paris, Gallimard, 1958.

Dıв, Mohammed. L'Arbre à dires, Essai, Paris, Albin Michel, I998.

Dів, Mohammed. L'Incendie, Paris, Le Seuil, I954.

Diв, Mohammed. La grande maison, Paris, Le Seuil, 1952.

Dıв, Mohammed. Le Métier à tisser, Paris, Le Seuil, I957.

Dів, Mohammed. Les terrasses d'Orsol, Paris, Sindbad, 1985.

Diв, Mohammed. Poésie, Euvres Complètes, La Différence, 2007.

Diв, Mohammed, Tlemcen ou les lieux de l'écriture, textes et photos de philippe Bordas, Paris, Bordas, La Revue Noire, 1994.

Djebar, Assia. Ces voix qui miassiègent, Paris, Albin Michel, 1999.

Grenier, Jean. Inspirations Méditerranéennes, Paris, Gallimard, 1939. 


\title{
LA IZQUIERDA SOCIAL Y EL ISLAM POLÍTICO: LA EXPERIENCIA ARGELINA
}

\author{
ILYA U. TOPPER \\ Editor Revista M'Sur Estambul
}

\begin{abstract}
Resumen
El islamismo político alcanza proyección mundial con la revolución contra el shah en Irán en I979 en la que colaboran colectivos marxistas e islamistas. Aunque acto seguido, Jomeini destruyó la izquierda iraní, el islamismo se considera hasta hoy una ideología asociada a la izquierda por su discurso antiestadounidense. Se hace fuerte en los países al sur del Mediterráneo gracias al respaldo de regímenes autoritarios que fomentan su expansión como contrapeso a la oposición izquierdista, algo especialmente visible en Argelia. Durante la Primavera Árabe, que surge de planteamientos laicos, los islamistas se hacen con el protagonismo (Egipto, Siria) o forman alianzas (Marruecos). Sin embargo, una coalición entre demócratas e islamistas suele acabar con la destrucción de los primeros: el islamismo busca imponer normas divinas incuestionables, algo especialmente visible en el papel que se reserva a la mujer. Las fuerzas demócratas en la actual rebelión de Argelia deberán evitar esta alianza.
\end{abstract}

Palabras clave: Islamismo, Argelia, democracia, izquierda, Primavera árabe, mujer

\begin{abstract}
Islamism as a political ideology reached world-wide prominence after the revolution against the Shah in Iran in I979, where Marxist and Islamist groups joined forces. A1though Khomeini destroyed the Left afterwards, Islamism is still considered as a leftist movement for its percieved opposition to the US. Islamist movements replaced Marxists in many Arab countries thanks to a strong support by autocratic regimes who fostered them in order to weaken the left-wing opposition, a phenomenon obvious in Algeria. During the Arab Spring, Islamists took over the secular uprisings (Egypt, Syria) or shaped an alliance (Morocco). Nevertheless, any coalition by democratic and Islamist forces usually leads to the destruction of the former by the latter: The goal of Islamists is to rule society by divine laws that cannot be questioned, especially when it comes to women's rights. Democratic forces in the uprising in Algeria today should avoid such an alliance.
\end{abstract}

Keywords: Islamism, Algeria, democracy, Arab Spring, Left-wing, women.

"Nada puede ser peor que continuar con el régimen", me dijo un miliciano sirio en verano de 20I2. "La nuestra era una revolución de la dignidad, 
pero lo dejó de ser porque nos han abandonado todos. Ya nos da igual lo que venga. Aceptaríamos ayuda hasta del diablo".

No era sorprendente. En la vida de todo movimiento contestatario llega un momento en el que sus militantes deben enfrentarse a un dilema: mantenerse en la irrelevancia política o pactar con algún poder fáctico para alcanzar influencia y poder llevar a la realidad su ideario. Hay quien está dispuesto a vender su alma al diablo con tal de triunfar. Pero en los países al sur y al este del Mediterráneo hay una alternativa aún más arriesgada, tentadora, una terrible trampa: vender el alma a Dios.

Lo hemos visto muchas veces. Quizás la primera vez en Irán en 1979, en lo que conocemos como "Revolución Islámica". El propio nombre es una falsedad histórica: la revolución no se basaba en un movimiento a favor de una opción religiosa sino contra un régimen dictatorial, el del shah Mohamed Reza Pahlevi. Su columna vertebral eran movimientos laicos, en gran parte de izquierdas: el variopinto Frente Nacional y el Tudeh comunista. Y la revolución no se habría desencadenado sin las protestas de periodistas, abogados, artistas, escritores ni sin la huelga general de octubre de 1978 , en la que participaban funcionarios, jueces, profesores y trabajadores de la industria petrolífera. ${ }^{1}$

Pero quizás estos movimientos tampoco habrían podido derrocar al shah, si no hubiera entrado otro factor: protestas masivas de un sector de la población conservador, fiel al clérigo exiliado Ruholá Jomeini. El frente unido barrió el régimen, el shah cayó.

Acto seguido, Jomeini y los suyos exterminaron el movimiento de izquierdas. Sin clemencia. Khomeini no llevaba aún un mes en el poder, cuando en las manifestaciones de las mismas personas que habían arriesgado su vida para derrocar al shah, ya se escuchaban los gritos: "Muerte a las mujeres sin velo". ${ }^{2}$

Irán se convirtió en una teocracia. Hasta hoy. El ejemplo debería haber demostrado que aliarse con los imames para reventar las cadenas de una dictadura es afianzarlas: un dictador puede morir; Dios es inmortal.

El militante izquierdista debe de ser de los pocos animales que tropiezan dos veces con el mismo dios. Porque el ejemplo de Irán cundió

1 Homa Katouzian (2009).

2 Lo relata en primera persona la activista y artista Farideh Lashai (2017). 
en todas partes, gracias al postureo "antiimperialista" de la teocracia iraní, que permitió a la izquierda admirar este régimen como defensor de los derechos del pueblo frente al "imperio". Olvidando, eso sí, que el pueblo también se compone de mujeres.

Las mujeres son el papel tornasol de una dictadura islamista: esta oprime con igual dureza a hombres librepensadores, artistas, músicos, filósofos, para no hablar de gays y amantes del amor libre. Pero como todos los movimientos islamistas han hecho bandera del velo impuesto a la mujer, este es un indicador, un sismógrafo para medir el grado de represión teocrática.

El postureo sirvió para que los movimientos islamistas pudieran convertirse en contrincante, primero, y heredero, después, de los movimientos marxistas en la mitad sur y oriental del Mediterráneo. Los dirigentes estudiantiles en las universidades de Marruecos, comunistas o maoistas capaces de fumar en ramadán, se vieron arrinconados en los noventa por una nueva generación que en lugar de El Capital enarbolaba el Corán, pero que utilizaba los mismos esloganes: justicia social, dignidad, rebelión de los desposeídos. ${ }^{3}$ Incluso calcaba la imagen: "En los setenta, llevar barba significaba que admirabas al Che", me dijo el periodista marroquí Mustafa Iznasni. Ahora, "barbudo" es sinónimo de islamista.

El Estado no fue ajeno a esta transformación. Desde Casablanca hasta Basora, los regímenes temían al comunismo más que ninguna otra cosa. $Y$ frente a ese enemigo estaban dispuestos a emplear todas las armas. No bastaba con el acoso policial, la cárcel, la tortura, las desapariciones, las ejecuciones. Había que quitarles no la vida sino la razón de ser. Había que crear una competencia.

Numerosos regímenes iban fomentando la aparición de células y movimientos islamistas. En Turquía, el servicio secreto militar directamente estableció, armó y entrenó en los años ochenta y noventa una milicia ultraislamista kurda, que se hizo llamar Hizbullah (sin relación con el partido libanés). Su finalidad: secuestrar, torturar y asesinar a miembros o simpatizantes de la guerrilla kurda marxista PKK. Y de paso, ocasional-

3 Este relevo fue encabezado por académicos musulmanes con estudios en Oxford, París o EEUU, según demostró Daniel Iriarte (2006). 
mente, lanzar ácido contra mujeres que no vistieran como dios manda. ${ }^{4}$

En otros países, el apoyo del régimen o de sus cloacas a los movimientos islamistas era menos directo. A menudo bastaba, simplemente, dejarles espacio. La policía hacía redadas en universidades, tabernas, talleres, asociaciones, periódicos, casas particulares... en todo lugar donde la ciudadanía pudiera reunirse a hablar de política. Salvo en las mezquitas. Quién quería hablar de política, se refugiaba en el templo. En la palabra de Dios.

Un caso espectactular fue Argelia, por el abierto apoyo que todos sus gobernantes prestaron al islamismo político. Desde Ahmed Ben Bella, que invitó a fundamentalistas egipcios para llenar las filas del Ministerio de Educación, pasando por Houari Boumediene, quien concedió a los religiosos el viernes como festivo oficial —entregando así una nación entera a las prédicas semanales_ - hasta Chadli Bendjedid, que multiplicó mezquitas y salas de rezo en universidades y fábricas y redujo los derechos de las mujeres a lo previsto en la charia. ${ }^{5}$ Todo ello para contrarrestar un enemigo que ni siquiera se podía describir como "amenaza comunista": en un país aliado de Moscú no había un adversario geopolítico a combatir. Toda la maquinaria islamista se dirigió contra simples demócratas y colectivos amazigh que se oponían a la arabización forzada del país. ${ }^{6}$ Conocemos el resultado.

El mismo proceso tuvo lugar en toda la franja sur del Mediterráneo. Anwar Sadat lo practicaba en Egipto, aunque ya el propio Gamal Abdel Nasser había iniciado la táctica. ${ }^{7}$ El dictador Sadam Husein recurrió al mismo sistema cuando se vio acorralado tras la fallida invasión de Kuwait: puso hasta la frase $A l \cdot l a b u$ Akbar en la bandera. Israel copió la idea ya en los ochenta: el movimiento de Hamás con un discurso islamista era fácil de vender como "irreconciliable" y "terrorista" a sus aliados europeos y además debilitaba a su principal enemigo, el laico Hamás. ${ }^{8} \mathrm{Su}$ crecimiento se debió al mismo modelo darwinista de la resistencia aplicado en otras

4 Suleyman Ozeren \& Cécile Van De Voorde (2006).

5 Rachid Oulebsir (2013).

$6 \mathrm{La}$ arabización y la islamización de Argelia eran procesos estrechamente vinculados. Ver Ali Guenon, (1999)

7 Así lo asegura Wassyla Tamzali en entrevista con Topper (2017).

8 Con detalle relatado por Ishaan Tharoor (2014). 
dictaduras: se persigue a todo bicho político laico y demócrata y se deja en paz al nicho ecológico de la mezquita.

El cálculo funcionó porque se basa en una ley casi biológica: la Mezquita no es democrática, no puede serlo, porque Dios no debate. Dios manda. Incluso si reducimos la democracia a su denominador más sencillo, el de una decisión tomada por mayoría, ninguna Constitución que reivindica una religión como fundamento de la legislación es democrática, aunque sea aclamada por mayoría absoluta. Porque impone al pueblo, incluidas las futuras generaciones, unas normas que no han sido debatidas nunca y no podrán ser nunca debatidas. Un pequeño círculo de hombres, una oligarquía, se arroga el poder de prescribir al pueblo la interpretación de la palabra divina. Una Constitución que no separa radicalmente la religión del Estado siempre es oligárquica, nunca demócrata.

Y por eso mismo, la Mezquita — lo mismo vale para la Iglesia - no será nunca una amenaza para ningún régimen dictatorial. Todo dictador puede hacerse con el favor de la oligarquía, instrumentalizarla, legitimarse con ella. La única amenaza - para ambos: para el dictador y la Mezquita- es la democracia.

En este estanque cayó la piedra de la Primavera Árabe. Hizo olas.

No fue una rebelión de los islamistas. Partió de una masa popular que se levantó porque, como dijo Oriana Fallaci, se puede oprimir un pueblo durante cien años, pero no durante cien años y un día. ${ }^{9}$ Si hubo antecedentes, hervores bajo la superficie, eran huelgas, movimientos sindicales; hay quien considera la gran huelga de obreros (¡y obreras!) del textil de Mahalla en del delta del Nilo en 2008 fue la verdadera revolución que cortó las patas del trono de Mubarak. ${ }^{10}$ Cuando la población salió en masa a la calle en El Cairo, en febrero de 2oIr, el dictador cayó en días.

Los islamistas vinieron después. Se apuntaron a Tahrir pasados los primeros días, pero de forma discreta, sin marcar presencia. Poco a poco fueron tomando posesión de la mítica plaza, se hicieron con el espacio. En el sentido literal: cuando miles de personas se colocan en fila rezando, la plaza es suya.

9 Oriana Fallaci (1979).

$10 \mathrm{El}$ papel de los sindicatos como fuerza social y política en los países árabes ha recibido poca atención frente a los movimientos religiosos. Ver Osman El Sharnoubi, (2013). 
Por supuesto no era un enfrentamiento. Todo lo contrario: se exhibía la buena sintonía entre laicos y religiosos practicantes, es decir fundamentalistas. Se integraba a los coptos también: celebrando misas. Una hermosa imagen de unidad, como celebraba el antropólogo Charles Hirschkind en 20II: superaba por fin el enfrentamiento entre laicos e islamistas "explotado tanto por Sadat como por Mubarak para debilitar la oposición”. En Tahrir, por fin, dice el autor, esa división no importaba. Nadie se preguntaba de qué bando era el otro. Los izquierdistas y liberales "nunca consideraron los rezos colectivos como una amenaza al carácter laico del movimiento". "Ni los participantes más devotos se escandalizaron porque hubiera música popular, no islámica, en la plaza, o poesía satírica, irreverente, géneros artísticos que los activistas religiosos en Egipto a menudo habían criticado como amenaza al carácter islámico de la sociedad egipcia”. ${ }^{11}$

Y esta es la clave: Los izquierdistas y liberales nunca consideraron como amenaza la exhibición pública de una ideología que pretendía destruir la cultura de su país y reemplazarla con una teocracia, es decir una dictadura sin fisuras. (Si existe algo así como una cultura árabe, la poesía irreverente y la música popular son elementos fundacionales de ella). No identificaron como peligro compartir la lucha por la democracia de la nación con quienes estaban dispuestos a acabar con la democracia y con la nación.

Se dieron de bruces con la realidad muy pronto. Hosni Mubarak cayó el ir de febrero de 20ir. El 8 de Marzo, los y las rebeldes convocaron una "Marcha del millón de mujeres" a Tahrir. Acudieron pocos centenares. Porque intuían lo que se iban a encontrar. Las mismas mujeres que habían conquistado Tahrir en febrero junto a los hombres - "allí durmieron, gritaron o se pasearon con sus demandas de democracia y libertad, a veces en grupos sólo femeninos, la mayoría del tiempo mezcladas con los hombres esgrimiendo banderas y vociferando consignas" cuenta la periodista Nuria Tesón - ahora se veían rodeadas de una contramanifestación de hombres dispuestos a echarlas con cajas destempladas. "Esto es lo que quieren los extranjeros. ¡Estáis debilitando nuestra revolución!” les gritaban a ellas. ${ }^{12}$

11 Charles Hirschkind (2012)

12 Lo vivió la periodista española Nuria Tesón, Nuria (2011). 
Porque la revolución, así lo interpretaron, era de los hombres.

En menos de un mes, Tahrir había pasado de plaza de la libertad a territorio del islamismo. Es decir, de una ideología antidemocrática, contrarrevolucionaria. Fue esa ideología la que tomó el poder en las elecciones, marginando a quienes se habían jugado el pellejo en Tahrir. Y pese a la enorme violencia y crueldad del golpe del mariscal Sisi contra el presidente Morsi, bajo la excusa de acabar con la deriva islamista de Egipto, la ideología que impone la actual dictadura de Sisi es tan islamista como lo fue la de Morsi, si no más. Los juicios contra artistas o intelectuales por "blasfemia", que ya arrasaron la vida cultural bajo los Hermanos Musulmanes, se han multiplicado bajo el mariscal. El golpe fue un simple traspaso sangriento de poder, no una confrontación de visiones distintas de la sociedad. No puede sorprender: fue Morsi quien había nombrado jefe ministro de Defensa a Sisi. ${ }^{13}$

El error de los jóvenes de Tahrir era no ver llegar el peligro. Era alegrarse (al igual que lo hace Hirschkind) de la "unidad del pueblo" como si "el pueblo" fuese un proyecto político. No lo es. El pueblo es lo mismo demócrata que fascista o estalinista: depende del ideario político del que se dote. No quisieron ver que los rezos públicos no son una expresión de la devoción popular. Rezar puede entenderse como una conexión personal con el Creador. Acudir en masa a una hora determinada de un día de la semana a un lugar público y colocarse en fila — segregada por sexos - no es un asunto espiritual: es una exhibición pública de la fuerza política de un colectivo determinado, y lo ha sido desde que se inventó. Al igual que la misa de domingo cristiana. Lo es en las calles de Marruecos, donde ha empezado a hacerse en la última década —en mi infancia era impensable-, lo es en las calles de Francia, donde expresa un rechazo al ordenamiento jurídico del Estado, y lo era en Tahrir.

Han hecho falta muchas décadas de misión fundamentalista, de salafismo promovido por el Gobierno, para creerse que una exhibición de un rezo colectivo forme parte de la "identidad del pueblo". Si esta identidad se expresa en un rito religioso homologado para todo el planeta, ya no existe el pueblo, solo existen lo que los católicos llaman ovejitas.

13 Mona Eltahawy lo explica con detalla en entrevista con Alejandro Luque (2019) 
Nadie quiso ver entonces que los tan celebrados rezos públicos y las misas expresaban un ideario de división: exhibían una sociedad sometida a líderes absolutistas —imames, obispos - opuestos al concepto de la ciudadanía con derechos iguales para todos. Unidad habría sido exigir los mismos derechos — no similares, sino los mismos- para coptos y musulmanes: derecho a casarse entre ellos, obligación a seguir las mismas leyes en todo, fuese divorcio o herencia. Y quiere decir: los mismos derechos para mujeres y hombres. Algo que rechaza explícitamente una misa cristiana - dirigida por un cargo que una mujer no puede ocupar- y un rezo musulmán — tres cuartos de lo mismo. Ambas religiones establecen una jerarquía basada en el sexo, una desigualdad jurídica ordenada por Dios. Ambas son antidemocráticas.

Pero ambas fueron aceptadas por los jóvenes de Tahrir como si fuesen aliados, y no adversarios, en la lucha por la democracia.

El resultado se vio el 8 de Marzo: los cientos de miles que acudieron a Tahrir, jugándose la vida para derrocar a un dictador, no tuvieron huevos de dar espacio a una manifestación que reivindicaba para la mitad de la población los mismos derechos que tiene la otra mitad. Hasta ahí llegaba su compromiso democrático.

Cuando pensadores, políticos o filósofos laicos del ámbito musulmán se oponen a que los movimientos islamistas participen en la política como un componente más de la sociedad se les dice que es antidemocrático excluir a los religiosos. Lo que raramente se dice es que es todavía mucho más antidemocrático excluir a la mitad de la nación que ha nacido con vulva.

La rapidez con la que la revolución de Tahrir fue secuestrada por los islamistas debería haber dado que pensar a los militantes de otras revoluciones 'primaverales'. No fue el caso. En Siria, donde habían confluido diferentes factores en una rebelión que fue primero pacífica y al cabo de unos meses se mutó en armada, nadie tomó nota. Ya pudo ser un error de cálculo enfrentarse con un puñado de fusiles de asalto a la maquinaria militar del régimen sirio. Pero el error mayor de los revolucionarios fue vender su ideario por un kalashnikov. "Aceptaríamos ayuda hasta del diablo", me repitió aquel miliciano en 2012 , en un café de la provincia 
turca de Hatay. ${ }^{14}$ Pero el diablo no estaba, no hizo acto de aparición, por mucho que lo conjurasen. Quien vino en su lugar fue Dios.

Esto fue el fin de Siria.

Porque Siria había existido como país, incluso como nación, durante décadas de opresión, de persecuciones políticas, encarcelamientos, torturas. Había existido bajo la cruel dictadura de Asad. Habría seguido existiendo si tras unos meses de guerra, los rebeldes, al verse abandonados por todos los posibles aliados, hubiesen tomado la amarga decisión de renunciar a la libertad y la dignidad soñadas. No lo hicieron. Vendieron su alma a los sicarios de Dios. Cuando podrían y deberían haber sabido cuál era el futuro que les esperaba en el caso de que ganaran: una dictadura con menos libertades aún que la de Asad, una teocracia que eliminaría en primer lugar a quienes habían pedido libertad y dignidad. Deberían haber sabido que desde el momento de aceptar un fusil pagado por Qatar o Riad estaban luchando y muriendo por su peor enemigo.

Por supuesto, también este giro de la guerra lo propició el régimen de Asad, en una repetición tantas veces vista de la trampa estratégica: durante meses, las manifestaciones se hacían los viernes al salir de las mezquitas. Porque el rezo era, una vez más, el único momento de la ciudadanía para reunirse sin que la policía interviniera. ${ }^{15}$ Así, las protestas se hacían bajo la impresión directa de un sermón religioso. Y de paso, sin apenas participación de mujeres: las mujeres no acuden al rezo del viernes. Esa exhibición pública de la devoción es cosa de hombres.

La revolución se convirtió en cosa de hombres mucho antes de llegar a guerra. Es decir que dejó de ser revolución. Todo lo que vino después, como la treta de Asad de liberar a millares de presos islamistas para que hicieran la rebelión por su cuenta, el germen del inhumano 'Estado Islámico' (Daesh), ya fue posible porque los rebeldes aceptaron la lógica islamista. ${ }^{16}$ Está claro que la destrucción de Siria mediante la herramienta del Daesh fue responsabilidad del régimen sirio, como lo fue toda la guerra (la negativa del régimen de convocar elecciones libres y democráticas lo convierte en responsable de cada una de las muertes

14 Topper (2012)

15 Javier Espinosa y Mónica G. Prieto en entrevista con Luque (2016).

16 Numerosos testimonios lo corroboran. Véase Speakman Cordall (2014). 
y las atrocidades cometidos por cualquiera de los bandos), pero también está claro que muchos en el bando rebelde se prestaron voluntariamente a colaborar en ella.

Porque los yihadistas no solo vinieron de las cárceles de Asad. En diciembre de 20II, el reportero Daniel Iriarte ya se encontró a los primeros enviados libios - con pasaportes europeos - en las colinas de Siria donde se pegaban los primeros tiros. Hubo quien les dio la bienvenida. ${ }^{17}$ Es fácil entender que una persona que haya pasado por las crueldades del régimen de Asad esté dispuesto a cualquier acción para acabar con el dictador. La desesperación y el deseo de venganza son reacciones humanas. Para lo que no sirven es para fundar una democracia.

Marruecos tuvo suerte de no caer en la misma espiral. Durante unos meses de la 'Primavera' — que en este país no cabe llamar árabe- se repetían las manifestaciones y protestas callejeras del Movimiento 20 de Febrero. El grupo era una alianza heterogénea de jóvenes que querían simplemente replicar movimientos reivindicativos como el de Túnez o Egipto con activistas de derechos humanos, militantes de diversos partidos de la izquierda y defensores de la cultura amazigh. Y como en todas partes, los islamistas llegaron prestos para sumarse al movimiento. ${ }^{18}$

El 2o-F los aceptó, pero con desconfianza: no dio espacio a su ideario, no permitió que su terminología o sus conceptos se colaran en los manifiestos. Seguían coreándose consignas por la igualdad de mujeres y hombres. No hubo rezos colectivos. Sin embargo, nadie ignoraba que la presencia del $20-\mathrm{F}$ como movimiento masivo en la calle dependía en parte de los militantes de Adl wal Ihsan, una corriente extraparlamentaria islamista no exactamente salafista pero fundamentalista religiosa. A diferencia de lo que pudo ocurrir en Egipto, sin embargo, los islamistas en Marruecos carecían del discurso político que sí tenían izquierdistas, militantes por las libertades individuales, activistas de derechos humanos, a menudo vinculados a movimientos con décadas de presencia en el debate público y la prensa.

La experiencia duró poco. La monarquía reaccionó con rapidez, haciendo gala de su proverbial habilidad política, combinando una represión

17 Daniel Iriarte (2012).

18 Ver el detallado análisis de Thierry Desrues (2012) 
mesurada con intentos de compra de colectivos o personajes cercanos al movimiento, y lanzando finalmente la gran operación cosmética de una nueva Constitución que dejaba todo como estaba. Tras menos de un año de protestas, los islamistas se retiraron de las marchas y el colectivo se fue desperdigando. ${ }^{19}$

Solo cabe especular qué habría ocurrido con la alianza contra natura, de haberse mutado en $20-\mathrm{F}$ en una fuerza capaz de determinar el futuro del país, algo de todas formas inverosímil visto el reparto de fuerzas. ¿Habrían conseguido los islamistas hacerse con el mando, como ocurrió en Egipto? ¿O habría conseguido la sociedad marroquí lo que parece conseguir - a duras penas y a costa de una permanente vigilancia - la tunecina: defender la democracia contra los islamistas que se apoderaron de ella?

Costó sangre en Túnez: la de activistas y diputados laicos, asesinados por fundamentalistas. Durante el año 20I2, con el partido islamista de Ennahda en el poder, se multiplicaron las noticias sobre actividades salafistas: asaltos a cines, exposiciones y locales de alcohol, intentos de acudir en niqab a la universidad... ${ }^{20}$ Probablemente no fueran más que anecdóticos, pero todo régimen fascista empieza con actos aislados. Es de admirar que la sociedad tunecina supo hacerles frente en las urnas, en el Parlamento, en la calle. Y una de las claves es que en Túnez, la revolución nunca se convirtió en cosa de hombres. Las mujeres estaban siempre en primera fila. Siguen estando. ${ }^{21}$

En esto, la revolución de Túnez se parece a las protestas de Gezi en Turquía en 2013. Es cierto que durante las dos semanas que duró la experiencia del parque Gezi, los "sublevados" (entre comillas: no hubo un enfrentamiento armado) hicieron el gesto de otorgar espacio a un rezo de una docena de participantes que se reclamaron "musulmanes anticapitalistas”, pero la escenificación se quedó en una anécdota folclórica. En Gezi dominaban las minifaldas y no hubo velos: romper todo estereotipo de "mujer decente" era parte esencial del movimiento. ${ }^{22}$ Porque se dirigía

19 Una pormenorizada descripción de este proceso la ofrecen Mounia Bennani-Chraïbi \& Mohamed Jeghllaly (2012).

20 Pérez De la Cruz (2012).

21 Pérez De la Cruz (2012)

22 Topper (2013) 
precisamente contra un Gobierno autoritario que proyectaba su poder mediante un ideario islamista. Queda en la memoria la frase que el presidente, Recep Tayyip Erdogan, lanzó más tarde contra los manifestantes: "Son izquierdistas, ateos, terroristas". ${ }^{23}$

Es posible que este factor también determine el futuro de la rebelión que se vive en estos momentos en Argelia, una especie de 'primavera' retardada. Un pueblo se ha levantado contra un régimen de muchas décadas, de los que los últimos 20 años, los que fingía estar en el poder Abdelaziz Bouteflika, son solo la coda final. Se trata de derrocar un sistema, en esto hay un evidente acuerdo en los manifestantes que salen a la calle, viernes tras viernes. Con certeza, los islamistas vuelven a estar prestos para secuestrar la rebelión. Pero es poco probable que lo logren: porque ya están en el poder.

Ya en el primero lustro del siglo XXI, los dirigentes del FIS encarcelados durante la guerra civil de los noventa volvieron a las mezquitas. En lo que parece el peor ejemplo de intento de reconciliación, el régimen fue dando prebendas y espacio a quienes había dicho combatir. Para una vez más, mantener al pueblo atrapado entre el fuego de la represión policial y la brasa del sermón del viernes. De enemigos, los radicales se convirtieron pronto en aliados de un poder que ahogaba toda libertad de prensa o de pensamiento. Censura de programas de televisión por “atentar contra los valores espirituales de la nación”, denuncias de diarios por "ateos", proliferación del hiyab... Se diría que el FIS, si bien perdió la guerra, ganó la posguerra: una década después de que sus militantes fueran aplastados a sangre y fuego, su causa se instaló en los despachos: Argelia se volvió islamista por la vía administrativa. ${ }^{24}$

Al levantarse ahora el pueblo, es de imaginar que su indignación no solo se dirija contra la figura de los generales que han impuesto su dictadura, sino también - como ocurre en Turquía - contra la ideología de la que se han servido para ejercer el control mientras fingían combatirla: la religiosa fundamentalista. "Los islamistas ya no tienen ninguna credibilidad en Argelia”, opina el reportero Marc Marginedas. La guerra

23 Mourenza, Andrés \& Topper, Ilya U. (2019)

24 Ángel Villarino (2006). 
civil mostró a lo que pudo llegar la confrontación/alianza de militares y yihadistas, unos usando a otros para imponer el miedo. ${ }^{25}$

Habrá que estar atento a las fotos de las manifestaciones. Por el momento veo marchas de mujeres y hombres juntos, melena al viento, veo eslóganes que piden la abolición del Código de la Familia basado en la sharia. Y mientras las mujeres siguen en primera fila, la revolución será posible.

"El pueblo quiere / la caída del régimen". El eslogan acuñado en la avenida Habib Bourguiba en Túnez y replicado en Tahrir, antes de extenderse al resto de la orilla sur del Mediterráneo, se debe referir no solo al dictador en el palacio, como dice Mona Eltahawy: también debe hacer caer la dictadura de la calle y la del dormitorio. ${ }^{26}$ Solo si cae esta triple dictadura, si la liberación del pueblo significa la liberación de la mujer, solo entonces hay libertad. Y para ello hay que evitar que la revolución la secuestren los sicarios de Dios. Dios no es demócrata.

\section{BIBLIOGRAFÍA}

Bennani-Chraïbi, Mounia \& Jeghllaly, Mohamed. 20I2. « La dynamique protestataire du Mouvement du 20 février à Casablanca », Revue française de science politique. 2012/5 (Vol. 62), p. 867-894.

Desrues, Thierry. 20I2. "Le Mouvement du 20 février et le régime marocain: contestation, révision constitutionnelle et élections ", L'Année du Maghreb. viII | 2012 : Dossier : Un printemps arabe, p. 359389. https://journals.openedition.org/anneemaghreb/1537?lang=en

El Sharnoubi, Osman. 20I3. "Revolutionary history relived: The Mahalla strike of 6 April 2008”. Al Ahram.6 Abril 2013. http://english.ahram. org.eg/NewsContent/I/64/68543/Egypt/Politics-/Revolutionaryhistory-relived-The-Mahalla-strike-o.aspx

Fallaci, Oriana. 1979. Un hombre, Barcelona, Noguer y Caralt Editores, (I984).

25 Comunicación personal de Marc Marginedas (2019).

26 Luque (2019). 
Guenon, Ali. 1999. Chronologie du mouvement berbère, un combat et des hommes. Éditions Casbah Alger, r999. Citado en: Amazighworld. http://www.amazighworld.org/history/amazighophobia/algeria/ boumediene/index.php

Hirschindn, Charles. 20i2. "Beyond secular and religious: An intellectual genealogy of Tahrir Square”. American Ethnologist. https:// www.academia.edu/15830065/Beyond_secular_and_religious_An_ intellectual_genealogy_of_Tahrir_Square

Iriarte, Daniel. 2006 "Los islamistas que vinieron de Occidente". La Clave, No 293. https://msur.es/2006/II/25/islamistas-occidente/

Iriarte, DANiEl. 20I2. "Los yihadistas acuden a Siria”. M'Sur. https:// msur.es/20I2/o8/15/siria-yihadistas-acuden/

Katouzian, Homa. 2009. "The Iranian Revolution of February 1979”. Middle East Institute. https://www.mei.edu/publications/iranianrevolution-february-I979.

Lashai, Ferideh. 20i7. Llegó el chacal. Ediciones de Occidente y Mediterráneo.

Luque, Alejandro. 20i6. "Javier Espinosa: 'Los medios se quieren parecer cada vez más a Twitter' ”. M'Sur. https://msur.es/20I6/II/I4/ javier-espinosa/

Luque, Alejandro. 2019. "Mona Eltahawy «Es más fácil elegir llevar hiyab que elegir quitárselo»", $M$ 'Sur. https://msur.es/2019/o4/o4/mona-eltahawy/

Mourenza, Andrés \& Topper, Ilya U. 20I9. La democracia es un tranvía. Ed. Península.

Oulebsir, RACHid. 20I3 "Algérie: l'islamisme à la conquête du pouvoir de 1962 à 1992 ». Le Matin d'Algérie. I Enero 2013. https://www. lematindz.net/news/Io682-algerie-lislamisme-a-la-conquete-dupouvoir-I962-I992.html

Ozeren, Suleyman \& Van De Voorde, Cécile. 20o6. "Turkish Hizballah: A Case Study of Radical Terrorism”, International Journal of Comparative and Applied Criminal Justice, 30: I, 75-93. 
Pérez De la Cruz, Javier. 20i2. "Los salafistas aparecen en Túnez". M'Sur. https://msur.es/20I2/o7/ri/salafistas-aparecen-tunez/

Pérez De la Cruz, Javier. 20I2 "La hora de la mujer”. M'Sur. https:// msur.es/20I2/ro/24/hora-mujer/

Speakman Cordall, Simon. 20I4 "How Syria's Assad helped forge ISIS”. Nerwsweek. Junio 20I4. https://www.newsweek.com/how-syriasassad-helped-forge-isis-25563I

Tesón, Nuria. 20II. "La revolución egipcia no puede con el machismo". M'Sur. https://msur.es/20II/o3/17/la-revolucion-egipcia-no-puedecon-el-machismo/

Tharoor, IshaAn. 20I4. "How Israel helped create Hamas". The Washington Post. 30 Julio 20I4. https://www.washingtonpost.com/ news/worldviews/wp/20I4/o7/3o/how-israel-helped-create-hamas/

Topper, Ilya U. 20I2. "Las falsas barbas de Siria". MSur. https://msur. es/2012/o7/23/falsas-barbas-siria/

Topper, Ilya U. 20I3. "La revolución y las minifaldas". M'Sur. https:// msur.es/20I3/o8/Io/topper-revolucion-minifaldas/

Topper, Ilya U. 20I7. "Wassyla Tamzali: «No necesitamos un islam moderado sino un islam valiente»". M'Sur. https://msur.es/2or7/o3/24/ wassyla-tamzali-I6/

Villarino, Ángel. 2006. "Vuelta a la mezquita". La Clave, no 268. 2 Junio 2006. https://msur.es/2006/o5/28/argelia-vuelta-mezquita/ 



\title{
L'ALGÉRIE TRANSITION INCERTAINE SUR FOND DE CRISE POLITIQUE ANNONCÉE
}

\author{
Laurence ThieuX \\ Universidad Complutense Madrid
}

\begin{abstract}
Resumen
Tras décadas de inmovilismo político, Argelia conoce desde el 22 de febrero de 2019 profundas transformaciones que cuestionan muchas de las ideas preconcebidas sobre la sociedad argelina. Las manifestaciones masivas, pacíficas y prolongadas de la población argelina contra el sistema político son inéditas y reveladoras de los profundos cambios que en el curso de las dos últimas décadas han transformado tanto la sociedad como el sistema de gobernanza de Argelia. El artículo aporta una reflexión sobre los factores económicos, sociales y políticos que explican la crisis política e institucional y sobre el papel del ejército en este proceso.
\end{abstract}

Palabras clave: Sociedad civil, Ejército Nacional Popular, transición, juventud, redes sociales.

\section{Résumé}

Après des décennies d'immobilisme politique, l'Algérie connaît depuis le 22 février 2019 des bouleversements profonds qui remettent en question bon nombre d'idées reçues sur la société algérienne. Les manifestations massives, pacifiques et prolongées de la population algérienne contre le système politique sont inédites et sont révélatrices des changements profonds qui au cours des dernières décennies ont transformé aussi bien la société que le système de gouvernance de l'Algérie. L'article revient sur les facteurs économiques sociaux et politiques qui expliquent la crise politique et institutionnelle actuelle ainsi que le rôle de l'armée dans ce processus.

Mots clés : Société civile, Armée Nationale Populaire, transition, jeunesse, réseaux sociaux.

Après des décennies d'immobilisme politique, l'Algérie connaît depuis le 22 février 2019 des bouleversements profonds qui remettent en question bon nombre d'idées reçues sur la société algérienne. Les mobilisations populaires, massives, pacifiques, nationales contre le système politique en place ont réussi en quelques mois à faire bouger les lignes d'un « pouvoir » ankylosé dans sa routine autoritaire et complétement déconnecté 
des aspirations, demandes et griefs d'une société algérienne en pleine transformation.

Si au départ le mouvement du 22 février, et ses premières manifestations à Kherrata en Kabylie ${ }^{1}$ visait surtout le cinquième mandat du président Abdelaziz Bouteflika, les demandes des manifestants ont rapidement ciblé toute la classe politique avec l'apparition de slogans dans les manifestations comme «Yetnahaw ga 3 » qui signifie « dégagez tous ».

Après deux décennies à la tête de l'État, le président Bouteflika affaibli par sa maladie depuis 2013 et incapable d'exercer ses fonctions a été finalement lâché par l'armée et forcé à démissionner le 2 avril 20I9, un peu plus d'un mois après le début du soulèvement populaire.

Depuis le début des manifestations, c'est l'armée, colonne vertébrale du pouvoir algérien qui a repris les choses en main et c'est le chef d'État major et vice ministre de la Défense Ahmed Gaïd Salah qui a donné le ton de la réponse $\mathrm{du}$ " pouvoir » en guise de réponse aux citoyens révoltés contre le système politique. Tout en affichant une volonté d'assumer un rôle d'arbitre dans cette confrontation, le chef d'État major, s'exprimant au nom de la " grande muette $»^{2}$ qui n'a jamais été aussi bavarde, a dans le cadre de ses visites aux différentes régions militaires prononcé une série de discours sur la situation politique de l'Algérie.

Cette prolixité de l'armée depuis le début de la crise marque une rupture avec la réserve habituelle de l'armée sur les affaires politiques. À travers ses discours ambigus, l'armée s'est essayée à un exercice d'équilibre compliqué entre d'un côté un soutien manifeste au mouvement populaire tout en prenant ses distances par rapport aux clans du pouvoir accusés de tous les maux et responsables de la crises politique du pays et d'un autre côté comme Institution garante de la stabilité de l'État et ses institutions. En dosant menaces, fermeté, laissez faire et complaisance, l'armée à travers les discours de Gaid Salah, et les éditoriaux de la revue

1 Avant la première manifestation du 22 février qui marque le début du mouvement, les appels à manifester sont apparus à Kherrata en Kabylie le 10 février voir à ce sujet : https://www.lemonde.fr/ afrique/article/2019/06/08/a-kherrata-aux-sources-du-soulevement-algerien_5473351_3212.html

2 Cette expression très utilisée en Algérie pour désigner l'armée, remonte à la IIIe République, en France, période durant laquelle les militaires, étaient privés de droits civiques. 
$\mathrm{E} 1 \mathrm{Djeich}^{3}$ en réponse aux manifestations des étudiants le mardi et du peuple algérien le vendredi ont dit tout et son contraire.

Mais depuis la démission du président le 2 avril, la feuille de route suivie par l'armée est très clairement définie : suivre coûte que coûte la voie tracée par la Constitution : activation de l'article Io2, désignation du Président du Sénat, Bensalah comme président intérimaire pendant 90 jours, maintien du gouvernement Bedoui nommé par le Président Bouteflika au début de la crise après le limogeage de Ouyahia et préparation de nouvelles élections pour le 4 juillet.

L'attachement de l'armée 4 à cette feuille de route et rejetée par l'ensemble du peuple algérien qui en "vendredirant " pacifiquement depuis février a clairement demandé la démission des $3 \mathrm{~B}$, le départ de ceux qui ont contribué à plonger l'Algérie dans la crise politique, et en fin de compte un changement radical de système politique.

Si l'armée avait certainement misé sur l'essoufflement du mouvement avec le début du ramadan elle a du finalement cédé et annuler les élections prévues pour le 4 juillet faute de candidats crédibles et l'échec annoncé d'un scrutin considéré comme illégitime et boycotté dès le départ. Pour l'armée une sortie de crise signifie avant tout le retour à l'ordre mais son obstination à imposer des solutions qui ne répondent en rien aux aspirations démocratiques du peuple algérien ne peut qu'alimenter le mouvement populaire contre le système.

L'armée est aussi restée sourde aux appels au dialogue de certaines personnalités issues du monde politique ou de la société civile ${ }^{5}$.

3 Voir les éditoriaux de la revue E1 Djeich de mars, avril, mai et juin 2019 : https://www.mdn. $\mathrm{dz} /$ site_principal/index.php?L=fr\#undefined

4 Le discours prononcé par Gaïd Salah à Ouargla (4ème région militaire et 4ème visite depuis le début de la crise) illustre l'ambiguité entretenue par rapport au mouvement populaire en mentionnant les risques de manipulation et de dérapage mais réitère aussi l'attachement de l'armée à la feuille de route tracée par la Constitution. Voir à ce sujet https://www.tsa-algerie.com/document-situation-politique-ce-qua-dit-gaid-salah/

5 Le fondateur de la ligue algérienne des droits de l'homme, Ali Yahia Abdelnour, l'ancien ministre Ahmed Taleb-Ibrahimi et le militaire à la retraite Rachid Benyelles ont lancé un appel le 18 mai 2019 au commandement de l'ANP, l'invitant à initier un dialogue " franc et honnête " avec des figures représentatives du mouvement citoyen (Hirak), des partis et des forces politiques et sociales qui le soutiennent. Voir à ce sujet : https://www.elwatan.com/edition/actualite/ali-yahia-abdennour-ahmed-taleb-ibrahimi-et-rachid-benyelles-lance-un-appel-pour-une-solutionconsensuelle-18-05-2019 
En se substituant aux représentants légaux des Institutions de l'État à la légitimité fortement érodée, Ahmed Gaïd Salah s'est aussi situé au cœur de l'impasse politique dans laquelle se trouve l'Algérie quatre mois après le début des manifestations.

\section{COMMENT EN EST ON ARRIVÉ LÀ ?}

Pour déchiffrer la crise politique et institutionnelle de l'Algérie et le rejet massif du peuple algérien du régime politique en place depuis l'indépendance du pays en 1962, il est nécessaire de remonter en arrière et décrire les mécanismes qui ont permis la résilience d'un système de gouvernance durant des décennies et plus particulièrement depuis l'élection en 1999 du président Abdelaziz Bouteflika au lendemain de la décennie noire (Dris Ait Hamadouche, L. y C. DRIS, 20I2).

Au cours des deux dernières décennies, le conglomérat de clans qui se sont partagés le pouvoir et les richesses de l'État en Algérie ont fonctionné en vase clos mais en essayant de maintenir un assez large réseau de clientèles qui cependant. Cet accaparement du pouvoir s'est réalisé à l'ombre d'une architecture institutionnelle de façade où les partis, la justice, le pouvoir législatif et exécutif ont été vidés de leurs pouvoirs au profit de cette gouvernance parallèle dirigée par les réseaux complexes (hommes d'affaires gravitant autour du clan présidentiel, services d'intelligence, hiérarchie militaire) constitués autour des opportunités économiques offertes par l'Etat (contrats publics, ...). Une corruption systémique dilapidant les ressources issues du secteur des hydrocarbures principalement (Serres, 20I9).

Lorigine de cette dérive politico-mafieuse des cercles proches du pouvoir remonte aux années 8o, une décennie de rupture avec une succession de crises qui vont modifier en profondeur les structures du pouvoir en Algérie. Tout d'abord la crise économique provoquée par la chute du prix des hydrocarbures en I986 et qui avait provoqué alors un processus d'endettement inégalé de l'État algérien a obligé la présidence de Chadli Bendjedid à libéraliser le système économique. L'Algérie a connu aussi à la fin des années 80 une crise politique et idéologique profonde, avec une remise en question globale de la légitimité de l'armée au cœur du pouvoir qui réprimait dans le sang les manifestations d'octobre i988. L'ouverture 
politique contrainte par la crise économique et un système politique en perte de légitimité débouchèrent sur l'adoption de la Constitution de 1989 et la fin du parti unique donnant libre cours à l'expression de la diversité identitaire et religieuse de la société algérienne. La montée de l'islam politique en Algérie dans les années 8o et l'arrivée en force du FIS dans le paysage politique algérien à la fin des années 80 précipitèrent la fin de cette courte période de libéralisation politique en Algérie (Thieux, 2008).

Toutes ces crises ont conduit à une remise en questions de la légitimité du pouvoir basé sur une rente historique, économique et sécuritaire (Mañé Estrada, A. Thieux, L. y Hernando de Larramendi, M. 20r6). Le chaos de la guerre civile des années 90 a aussi menée à une reconfiguration politique du pouvoir. Bouteflika à son arrivée à la présidence en I999, parachuté par l'armée pour restaurer une image favorable de l'Algérie à l'extérieur et redonner un pouvoir civil à une Algérie meurtrie par une décennie de violence sauvage produite par l'affrontement entre l'armée et les groupes islamistes armés, ne voulait pas être un 3/4 de président. Depuis son arrivée au pouvoir, il n'a eu de cesse de reconstruire son pouvoir, le consolider en utilisant ses atouts diplomatiques d'un côté et l'opportunité qui se présentait de devenir l'homme de la réconciliation nationale.

Dans ce processus cependant Bouteflika devait composer avec l'armée d'une part et en son sein les services d'intelligence (le DRS) qui au cours de la décennie noire avaient acquis un poids prépondérant. C'est au cours des années 90 que l'armée s'impliqua directement dans la gestion politique du pays après l'interruption du processus électoral en janvier 92 pour éviter une victoire prévisible du FIS au deuxième tour des législatives que l'armée. Son image en est sortie fortement dégradée. Le capital social extérieur de Bouteflika devait permettre à l'Algérie de sortir de l'isolement et revenir sur la scène internationale (Belkaïd, 2009).

La présidence de Bouteflika a cependant été dès le départ entachée par un déficit de légitimité, ses six rivaux à la présidentielle s'étant retirés d'un scrutin en raison du manque de transparence et de liberté. Afin de pallier ce handicap de départ Bouteflika s'emploiera à renforcer sa légitimité vis à vis du peuple et surtout sa position interne vis à vis de l'armée en exploitant ce qui précisément avait décidé l'armée à faire appel à lui. Tout d'abord, son capital social extérieur lui permis de regagner la confiance 
des pays occidentaux, sur la base d'une nouvelle narrative présentant la guerre contre les groupes armés islamistes comme une bataille d'avant garde contre le terrorisme islamiste nouvel ennemi des Etats Unis après les attentats du in septembre. Ensuite il s'agissait de consolider son pouvoir en interne. La Concorde civile en 1999 puis la Charte de réconciliation nationale en 2005 ont renforcé la position du président qui devenait l'homme qui avait réussi à restaurer la paix en Algérie : une narrative qui résiste peu à l'épreuve des faits. On doit en effet les premières initiatives de paix avec les islamistes au Président Zeroual qui en 1997 initiait la Rahma et signait les accords de paix avec l'AIS, la branche armée du FIS. D'autre part loin de constituer un véritable processus de vérité et justice, la charte approuvée par référendum en 2005 ne faisait que tourner la page sur une décennie tout en interdisant de revenir en arrière (Dutour, 2008). Ainsi la Charte criminalise dans son article 46 « quiconque qui, par ses déclarations, écrits ou tout autre acte, utilise ou instrumentalise les blessures de la tragédie nationale, pour porter atteinte aux institutions de la République algérienne démocratique et populaire, fragiliser l'Etat, nuire à l'honorabilité de ses agents qui l'ont dignement servie, ou ternir l'image de l'Algérie sur le plan international $»^{6}$.

Bien qu'essentiels ces deux éléments nétaient pas suffisants pour asseoir le pouvoir du Président et de ses proches au sein d'un système collégial où l'armée avait toujours le dernier mot. La stratégie suivie par Bouteflika a consisté à élargir sa base de pouvoir en diversifiant ses soutiens et en intégrant de nouveaux acteurs économiques émergents après la libéralisation de l'économie algérienne. Ces entrepreneurs qui ont fait des fortunes grâce aux largesses de l'État en matière de contrats publics, avantages fiscaux et autres pratiques plus douteuses et qui sont ciblés aujourd'hui par l'opération main propre de l'armée. Le clan présidentiel a aussi réussi à se défaire des « janviéristes ", les décideurs des années 90. Avec la mise à la retraite du général Lamari qui était à la tête de l'état major de l'armée et en le remplaçant par Gaid Salah, Bouteflika réussis-

6 La Charte pour la Paix et la réconciliation Nationale a été approuvée par 97,36\% des voix et avec une participation de 82,04\%. Ver Thieux, L. https://iecah.org/index.php/articulos/739-la-carta-para-la-reconciliacion-nacional-en-arhttp://www.interieur.gov.dz/index.php/ fr/dossiers/168-la-charte-pour-la-paix-et-la-reconciliation-nationale.html\#faqnoanchorgelia-un-plan-de-amnistia-que-deja-heridas-abiertas 
sait en 2004 son premier coup de force. En 2008 afin de parachever une entreprise de longue haleine le président modifiait la Constitution afin de pouvoir briguer un troisième mandat ce qui sera chose faite en 2009 .

Les « printemps arabes » n’ont pas altéré la continuité politique du régime. L'adoption de réformes superficielles et quelques concessions sans impact n'ont altéré la nature du système politique. L'utilisation du chantage de la peur, le rappel des vieux démons susceptibles de replonger l'Algérie dans un cycle infernal de violence avec en toile de fond les chaos libyen et syrien ont freiné l'émergence d'un front de contestation politique. La manne pétrolière, encore abondante début 201 en raison de la tendance à la hausse du prix des hydrocarbures qui s'est maintenue jusqu'en 20I3, a aussi permis d'acheter la paix sociale à travers une redistribution élargie de la rente qui a calmé pour un temps les revendications économiques et sociales. En Algérie, il faut le rappeler, la population n'a jamais cessé d'exprimer son mécontentement depuis les années 2000, et principalement sous forme de micro-révoltes localisées (Thieux, L. y Hernando de Larramendi, M. 2019).

La permanence de cette insatisfaction sociale qui touche particulièrement les régions périphériques de l'Algérie est révélatrice des déficiences des politiques publiques mises en place, incapables d'enclencher un processus de développement durable sur l'ensemble du territoire national malgré l'abondance des ressources naturelles disponibles et les richesses accumulées par l'État (Belakhdar, 2015). Ces révoltes sont aussi le signe de l'absence de mécanismes de médiation entre ceux qui dirigent le pays et la société.

Après des décennies de répression et autres stratégies insidieuses déployées par le pouvoir la société civile algérienne a été affaiblie et neutralisée. Les organisations qui ont essayé de créer des espaces d'expression et d'action autonomes vis à vis du pouvoir ont été systématiquement privées de ressources et d'espaces pour mener à bien leurs activités (REMDH, 2OI2).

Ces associations, ${ }^{7}$ qui ont eu le mérite de résister dans un contexte très hostiles sont toujours présentes et depuis le 22 février elles ont re-

7 Le groupe solidarité Algérie représente en partie ce noyau d'organisation qui s'est toujours maintenu dans l'opposition au système (Le collectif des familles de disparus, RAJ, LADDH, les Syndicats Autonomes regroupés autour de la Conféderation des syndicats algériens (CSA), le réseau 
joint le mouvement populaire et l'accompagne dans sa structuration. Ces organisations regroupées autour du collectif de la société civile tentent aujourd'hui de devenir des forces de proposition pour la période de transition. Le Collectif de la dynamique de la société civile pour une transition démocratique ; la dynamique autour de la Confédération des syndicats algériens et le collectif civil pour le changement qui essayent actuellement de fédérer et articuler leurs propositions afin de proposer une seule feuille de route pour une sortie pacifique de la crise ${ }^{8}$.

Cette société civile empêchée par les tracasseries administratives et les harcèlements fréquents des forces de sécurité est aujourd'hui en train de récupérer le temps perdu, en se réappropriant l'espace public, en redynamisant le débat et en essayant de jeter des ponts avec une jeunesse qui a été au cœur du mouvement populaire depuis le début.

Cette jeunesse algérienne que l'on découvre dans toute son ingéniosité, sa détermination et son intelligence a réussi à marquer une nouvelle étape de la vie politique algérienne. Les jeunes en Algérie sont nombreux (les moins de 25 ans représentent $40 \%$ de la population), mieux éduqués. Il faut rappeler ici que le nombre d'étudiants en Algérie à été multiplié par 4 en 20 ans : ils étaient en 1999 425.000 et il y a maintenant en Algérie I,7 millions d'étudiants dont un tiers sont des filles 9 . La pénétration rapide d'Internet, des Smartphones et des réseaux sociaux ont aussi permis à cette jeunesse de trouver des espaces d'expression alternatifs sur le net.

\section{CONCLUSIONS}

Le face à face qui oppose l'armée et le mouvement populaire en Algérie qui rejette la feuille de route proposée par le pouvoir parce que celle-ci ne permet pas d'assurer un véritable changement du système au pouvoir. Aucune concession significative, trois mois après le début du soulèvement populaire, n'a été faite par le pouvoir. Les mêmes personnalités sont encore en place : le premier ministre Bédoui, le président intérimaire

des avocats, entre autres. Voir à ce sujet : https://euromedrights.org/fr/membres/

8 Ces trois dynamiques ont tenues plusieurs réunions qui ont réuni 71 associations et syndicats, Voir à ce sujet : https://www.tsa-algerie.com/la-societe-civile-face-a-une-responsabilite-historique/

9 Meyer, J.B (2019): “ Les étudiants, clé du changement en Algérie, Le Monde (11/03), disponible en https:/www.lemonde.fr/afrique/article/2019/03/11/les-etudiants-cle-du-changementen-algerie_5434510_3212.html?xtmc=etudiants_algerie\&xtcr=10 
Bensalah et institutions sont toujours aux commandes et ne peuvent garantir le changement escompté.

Malgré les déclarations favorables au mouvement, les détentions fracassantes des proches du clan Bouteflika et des ex-responsables des services de sécurité ${ }^{10}$ et l'opération main propre contre les oligarques proche du pouvoir ${ }^{11}$, les dénonciations de complots et les règlements de compte ne répondent pas non plus aux aspirations démocratiques du peuple algérien qui demande clairement une transformation profonde du système de gouvernance. Le processus sera certainement long et semé d'embuches. Même si la société civile est affaiblie, elle a montré son dynamisme depuis le début des marches du Hirak et elle est essentielle au succès du processus. Il n'est pas vain de rappeler ici le rôle clef que la société civile tunisienne à jouer dans le processus de transition : un rôle de veille, de proposition et de guide pour atteindre les objectifs de la « révolution ». Mais en Algérie, l'armée est le pilier du système et elle n'entend pas céder dans un contexte régional et international qui s'incline plutôt vers la contre-révolution que vers les démocraties incertaines.

\section{RÉFÉRENCES BIBLIOGRAPHIQUES}

Belakhdar, Naoual. « « L'éveil du Sud » ou quand la contestation vient de la marge. Une analyse du mouvement des chômeurs algériens ", Politique africaine, vol. 137, $\mathrm{n}^{\circ} \mathrm{I}, 2 \mathrm{O} 5$, pp. 27-48.

Belkaï̀, Aкram. « La diplomatie algérienne à la recherche de son âge d'or. » Politique étrangère, 2009, $\mathrm{n}^{\circ}$ 2, pp. 337-344.

Dris Aït Hamadouche, Louisa; Dris, Chérif. « De la résilience des régimes autoritaires: la complexité algérienne ». L'année du Maghreb, 20I2, no VIII, p. 279-30I.

10 Le frère de l'ancien président Abdelaziz Bouteflika, et les ex-patrons du renseignement - Mohamed Mediène, dit Toufik, et Athmane Tartag, dit Bachir ont été arrêtés en mai 2019 pour complot contre l'armée. https://www.jeuneafrique.com/771049/societe/algerie-said-bouteflika-et-deux-ex-patrons-du-renseignement-places-en-detention-provisoire/

$11 \mathrm{https} / / / w w w . l e p o i n t . f r / a f r i q u e / l e s-d e s s o u s-d e-1-o p e r a t i o n-m a i n s-p r o p r e s-e n-a l g e-$ rie-01-05-2019-2310290_3826.php 
Dutour, Nassera. «Algérie: de la Concorde civile à la Charte pour la Paix et la Réconciliation nationale: amnistie, amnésie, impunité ", Mouvements, 2008, $\mathrm{n}^{\circ}$ I, pp. I44-I49.

Mañé Estrada, Aurèlia; Hernando de Larramendi, Miguel; Thieux, Laurence. Argelia en la encrucijada: condicionantes, tendencias y escenarios, Fundación Alternativas, 2016.

REMDH, Rapport Algérie : "Réformes politiques » ou verrouillage supplémentaire de la société et du champ politique en Algérie?, 20I2, disponible en : https://euromedrights.org/fr/publication/rapport-algerie-reformes-politiques-ou-verrouillage-supplementaire-de-la-societe-et-du-champ-politique-en-algerie/

Serres, Thomas. L'Algérie face à la catastrophe suspendue. Gérer la crise et blâmer le peuple sous Bouteflika (1999-20I4). Karthala, 2019.

Thieux, Laurence et Hernando de Larramendi, Miguel. “2. Transformaciones y procesos políticos y sociales en el Norte de África desde 20II”. Informe África, p. 23.

Thieux, Laurence. "Sociedad civil y cambio político y social en Argelia: evolución de discursos y estrategias". Revista de Estudios Internacionales Mediterráneos, 2018. I0.15366/reim2018.25.005

Thieux, Laurence. Islamismo y democracia en Argelia: Francia y Estados Unidos frente al conflicto, Ediciones del Oriente y del Mediterráneo, Madrid, 2008. 


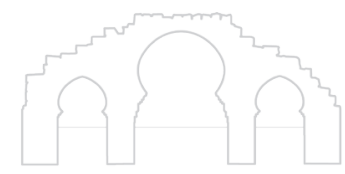

Reseñas y comentarios bibliográficos 

Nabil Ziani, Les berbères dans la Bible. Des origines à la fin des temps, París, Tatamis, 2018, 250 pp. [ISBN. 978-23-71530-485]

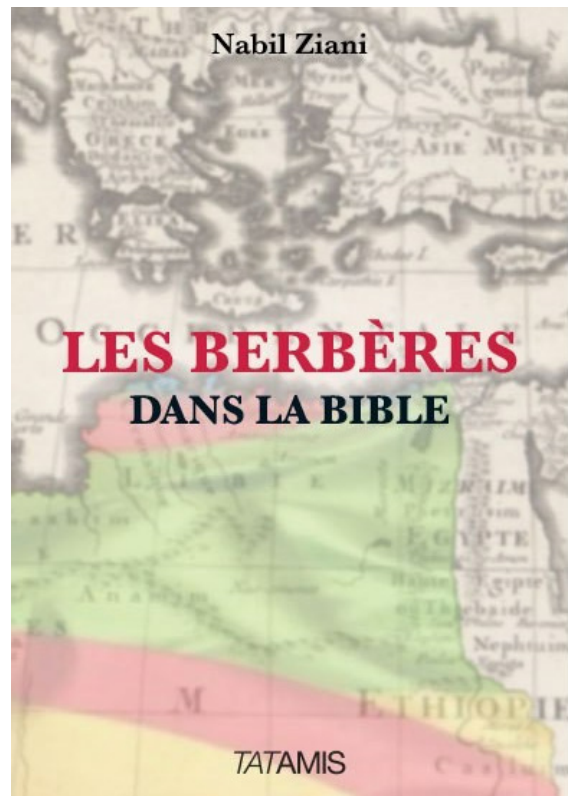

Les berbères dans la Bible es una monografía escrita por Nabil Ziani, cuyo interés principal es recopilar y analizar las citas bíblicas sobre el pueblo bereber. El autor, documentalista de formación, periodista e investigador, presenta una serie de materiales extraídos de la Biblia con el fin de conocer la percepción que se tiene de esta comunidad en una de las fuentes fundamentales de la Antigüedad.

Según afirma el autor, la publicación de este volumen es tan importante como necesaria. $\mathrm{Su}$ afán en demostrar los origines del pueblo bereber en general, y del argelino en particular, lo que le lleva a adentrarse en el texto bíblico. De hecho, el autor va más allá de la cuestión identitaria y busca el origen de los bereberes, tema controvertido durante siglos.

A menudo, tanto los pueblos como el territorio del norte de África han sido designados con diferentes nombres. Los habitantes del Magreb se han preguntado a menudo sobre sus orígenes, identidad y civilización. Incluso hoy en día, estas preguntas siguen sin estar resueltas, y siguen todavía existiendo grandes divergencias e incógnitas, que la arqueología y otras disciplinas anexas a la historia tratan de paliar. Como documentalista de formación y periodista de profesión, el autor indaga y hace 
preguntas directamente a las fuentes históricas, para obtener respuestas y proporcionar a los investigadores, y al público en general, datos sobre los que reflexionar.

Fue un bereber el que ayudó a Jesús a llevar su cruz, y otro bereber saqueó el templo de Salomón. El hallazgo de estos datos supone un desafió para Nabil Ziani, por lo que se decide a llevar a cabo una investigación minuciosa en las fuentes bíblicas para seguir el rastro y presencia de otros personajes norteafricanos en la Biblia. La lectura que hace le permite encontrar rastros de la presencia de este pueblo en diferentes partes del Tanaj y el Nuevo Testamento, aunque ni los nombres amazigh ni berber figuran en ella. Si Abraham fue el padre de los hebreos, el autor se pregunta: ¿Quién fue el patriarca del pueblo bereber? ¿Cómo evolucionó esta comunidad y por qué su rastro desapareció, prácticamente, de la historia oficial? ¿Cómo se fue transformando su identidad con las diferentes civilizaciones instaladas en el norte de África? ¿Cuál es el lugar de los bereberes en el desarrollo de la civilización humana? Y, en última instancia, ¿cuál es su futuro?

Este texto ve la luz después de cinco años de investigación, fruto de un riguroso trabajo de hermenéutica e historia bíblicas. La Biblia forma un único volumen compuesto por varios libros organizados en el Nuevo y el Antiguo Testamentos, compuesto por unos cuarenta autores en diferentes periodos. Los escritos de Moisés datan de hace tres mil quinientos años. Las primeras huellas de los bereberes ya pueden encontrarse en la Torá o el Pentateuco, según señala Nabil. A estos primeros datos hay que añadir los libros de los Reyes, los de las Crónicas y los libros de los Profetas, donde se recogen numerosas menciones a los bereberes.

Muchos profetas del Antiguo Testamento mencionan este pueblo norteafricano en sus escritos, bajo el nombre de puth o libios. Los profetas Jeremías, Ezequiel, Daniel y Nahúm los llaman de estos modos, mientras que Isaías los menciona como pul. Además, y sin nombrarlos de forma explícita, algunos textos parecen referirse a ellos. En el Nuevo Testamento son citados más a menudo personajes de origen bereber, aunque asumiendo que forman parte del mundo romano. Así Simón de Cirene, su esposa, Alejandro y Rufo, sus hijos; Lucio de Cirene; y un largo etcétera que detalla Nabil Ziani. 
En resumen, la obra presenta una serie considerable de datos acerca de las comunidades autóctonas del norte de África en la antigüedad, y su percepción por una fuente esencial en la reconstrucción de este mundo. La Biblia, como fuente histórica, puede ofrecer datos para la reflexión y la reconstrucción de valores culturales, no sólo para el lector especialista, sino para el público en general.

Naima Benaicha Ziani 

Hugh Roberts, Berber Government: The Kabyle Polity in Pre-Colonial Algeria, Londres, I.B. Tauris, 2014, 352 pp. [ISBN: 978-1845112516]

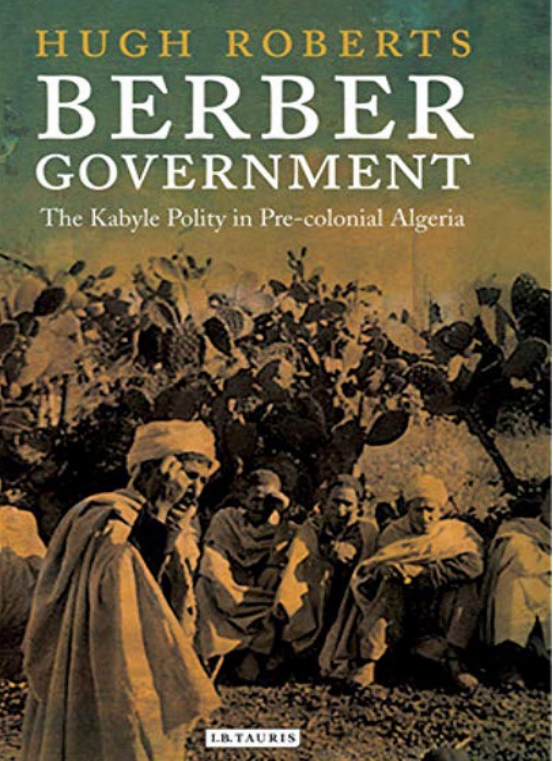

Las estructuras sociales de representación popular han sido necesarias desde que las sociedades humanas se convirtieron en agrupaciones complejas con un sistema de ordenación más elaborado. En el mundo araboislámico se han dado varias de estas estructuras representativas, con diferente resultado, a lo largo de la historia y, por supuesto, el mundo musulmán magrebí de la edad moderna no ha sido una excepción.

Esta etapa de la historia de Argelia, punto central del estudio del presente libro - y que el propio autor categoriza como "precolonial"-, hace referencia al periodo de finales del siglo XVIII y comienzos del XIX, cuando esta región no estaba, efectivamente, colonizada por potencias occidentales, como acabaría ocurriendo posteriormente (si bien cabe mantener en mente que este territorio se encontraba, desde tiempo atrás, sometido al control político otomano, fruto de la expansión territorial que la Sublime Puerta experimentó en su avance en la región del norte de África.

$\mathrm{Y}$ es que, dada su posición geográfica estratégica, sobre todo dentro del marco de las relaciones interestatales del Mediterráneo, Argelia ha sido históricamente el escenario de encuentros y desencuentros entre el pueblo amazigh, Europa y Medio Oriente, sobre todo con el control 
otomano la región del Magreb, primero, y con la colonización europea por parte de Francia, después. Esta confluencia tuvo un impacto directo en las estructuras de las instituciones de la Cabilia argelina, tales como la ŷama' $a$ o consejo, y en la forma de comprender la profundidad de estas figuras en el marco de la ordenación de la vida beréber. Estas instituciones, estudiadas sobre todo por etnógrafos del siglo XIX de la talla de Ernest Gellner y Pierre Bourdieu, se han venido entendido tradicionalmente no tanto como un sistema genuino de organización política beréber, sino como una figura cuya función tenía más de gestión de la estructura social y religiosa. Conclusiones asentadas en la tradición de Bourdieu y Gellner marcaron la aproximación de los futuros académicos que estudiaron el tema durante el siglo XX.

Es aquí donde la propuesta multidisciplinar de Roberts rompe con la tendencia establecida hasta el momento. Para él, las estructuras esenciales de la Cabilia argelina, no solamente la ŷma'a, se deben someter a una revisión histórica crítica para determinar los intrincados elementos políticos y jurídicos que revestían estas instituciones, y se dispone a lo largo del libro Berber Government: The Kabyle Polity in Pre-Colonial Algeria a acometer dicha tarea, con especial énfasis en el autogobierno y en las relaciones que mantenía la ŷama'a con el control político-jurídico otomano. Además, trata de pergeñar una explicación alternativa a la formación originaria del sistema gubernativo de la región de la Cabilia, analizando las características que mantenía en el momento previo a producirse la colonización francesa.

Se trata, en definitiva, de una obra que viene a proponer una revisión de las figuras de regulación política beréberes desde un punto de vista multidisciplinar y con una marcada crítica desde el punto de vista histórico, que comprende una reformulación del sistema político argelino. Abarcando cronológicamente la última etapa de control otomano hasta el comienzo del dominio francés, el libro propone una nueva forma de entender el complejo panorama de autogobierno que revestían las instituciones de la Cabilia beréber, manteniendo una visión histórica de las mismas que probablemente extiende sus efectos hasta los tiempos actuales. 
Mustapha Chérif,

Tolerancia e intolerancia en el islam,

Barcelona, Bellaterra, 2008, 241 pp. [ISBN: 978-84-7290-411-8]

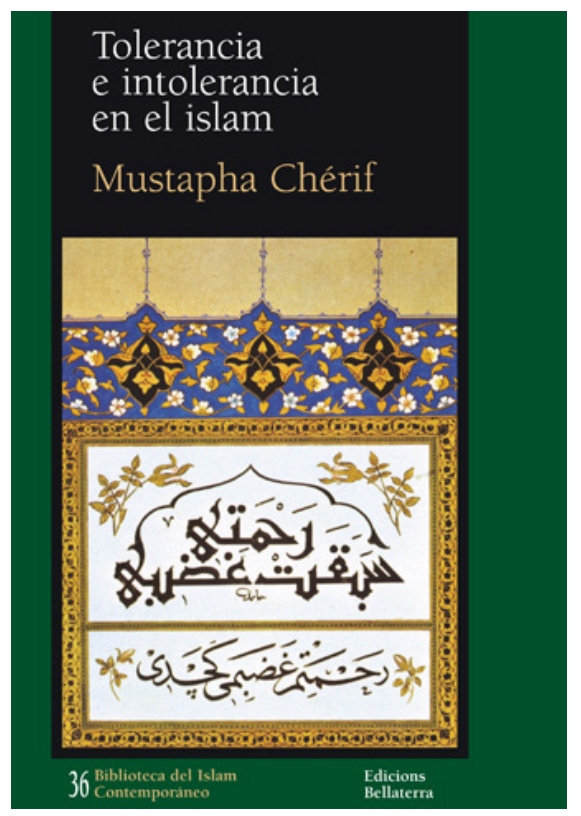

Lo cierto es que han pasado algunos años ya desde la publicación de la traducción española del libro L'Islam, tolérant ou intolérant? (2006), colección de dos conferencias impartidas por Mustapha Chérif en el Collège de France en la primavera de 2004. En efecto, son muchos los fenómenos concernientes al Islam y la vida de los musulmanes que desde entonces se han podido alterar a nivel planetario. Pero creemos que existe una permanencia, una reflexión perenne a la naturaleza del Islam, que el presente libro ayuda a desentrañar. De ahí su vigencia, y seguramente su validez para muchas décadas por venir. La idea clave del filósofo argelino Mustapha Chérif es la naturaleza abierta del mensaje islámico ("si se siguen bien las orientaciones del Corán, respetar el derecho a la diferencia y la libertad del otro no sólo es posible, sino exigido", p. 54). Esboza para ello diez dimensiones que manifiestan apertura - humana y humanística — del musulmán respecto a su entorno social y natural: el otro es semejante, la vida es misterio, libertad, desafío de vivir, piedad, carácter sagrado de la vida, el llamamiento del más allá, la paz, la justicia y la palabra.

Frente a la naturaleza abierta del mandato coránico, y los preceptos en la búsqueda del mensaje transcendente en esta vida y en el más allá, el llamado "Islam de las luces" es apagado por corrientes cerradas, un repliegue 
del contexto en el que se produjo la Revelación que Chérif atribuye a " $a l$ gunos defensores o adeptos de la religión como ideología, que operan con dudosas apariencias [...] y pretenden ser los portavoces de los creyentes" (p. 92). Para el autor argelino tan dañino como el repliegue (que sitúa en Ibn Taymiya) es la disolución, corriente de pensamiento que denomina "modernista" y cuya naturaleza externa niega los hechos de fe que determinan al Islam: "Aunque la idea de hacer evolucionar los aspectos paralizadores de la cultura y liberar el pensamiento y la política de la teología sea admisible, imponer a cambio normas que no tengan en cuenta lo que el Corán dice de sí mismo e ignorar las experiencias emancipadoras del islam, es dar prueba de amnesia y parcialidad" (p. 90).

El volumen lo conforman dos partes de temática relacionada que son fruto de dos conferencias previas. La primera parte "El musulmán y el otro" trata de las dimensiones islámicas que hacen que este mensaje religioso exija al creyente una vocación tolerante con el entorno de su existencia. Después se hace revista de los principales pensadores históricos del Islam, para reflexionar por último sobre la disolución y el repliegue, las dos corrientes extremistas que afectan la medianía exhortada por el Corán. La segunda parte "Los musulmanes y la mundialización" analiza en diez puntos la relación de la comunidad de creyentes y del musulmán como individuo en un mundo capitalista. Frente a la deshumanización, laicismo y estado ateísta que antepone las leyes del mercado a la dimensión mistérica de la existencia, Chérif señala que "no hay futuro deseable si la creatividad, la crítica constructiva de uno mismo y del otro y la apertura al cambio no son puestas en funcionamiento. No es cuestión de resistir por resistir, lo que no puede llevar más que a extremismos [...] La mundialidad, la modernidad, la mundialización se basan en medios decisivos e insoslayables, la ciencia y la técnica" (p. 226).

Volumen introducido por un prefacio del filósofo francés Jean-Luc Nancy, y con numerosas referencias a Jacques Derrida — gigante del mundo moderno nacido en El Biar-, la presente obra es un espléndido texto para conocer a uno de los pensadores argelinos actuales con mayor repercusión internacional. Islamólogo, antiguo ministro de educación y embajador en El Cairo, Mustapha Chérif posee una dilatada carrera profesional que lo convierten en voz autorizada de la reflexión intelectual argelina, el diálogo interreligioso y el pensamiento islámico actual. 


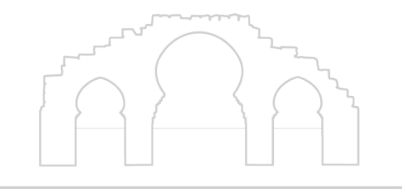

Biblioteca 



\title{
EL FEMINISMO ANTE EL MOVIMIENTO DEL 22 DE FEBRERO:
}

LA REVOLUCIÓN POR LAS MUJERES

\author{
Wassyla TAMzali \\ Escritora
}

Entrevista electrónica realizada por Naima Benaicha Ziani y respondida, el 15 de junio de 2019, desde Argel. Traducida del original en francés, en ella Wassyla Tamzali responde a un interlocutor imaginario, que puede ser cualquiera de los lectores.

Desde el 22 DE febrero, un MOVIMiento comenzó a Movilizar A millones de personas en Argel. El 8 de marzo, 20 millones estaban en la CAlle del país. Para usted QUe EXPerimentó la EUFORIA DE LOS PRIMEROS DÍAS DE LA INDEPENDENCIA Y TODAS LAS DESILUSIONES, MÁS CONCRETAMENTE SOBRE LAS MUJERES, ¿QUÉ DICE ACERCA DE ESTA SITUACIÓN?

Una gran esperanza que, desde el principio, persiste de cierta manera. En medio de esta euforia general, fui la primera en hablar sobre las mujeres, en hablar sobre la minoría feminista que representamos, en hablar sobre el secularismo, diciendo que sólo estos dos puntos pueden garantizar la democracia a la que todos se refieren sin dar detalles sobre cómo alcanzarla. Las mujeres caminaron junto al resto del "pueblo", un término que constantemente vuelve al escenario político-social en Argelia. Mi experiencia me dice que hasta hoy «el pueblo» ha jugado siempre y principalmente en contra de las mujeres. A mi alrededor tuve dificultades para hacerme oír. No debemos romper el movimiento, debemos permanecer unidos. (Conmoción al pronunciar estos argumentos). Yo también quería que «esta revolución» tuviera éxito. Y luego, ¿cómo no dejar brotar todas estas esperanzas cuando 20 millones de argelinos salen a las calles en un 8 de marzo? Estaba en la plaza de la República en París y con un megáfono me pidieron que diera mis impresiones. Dije lo que llevo diciendo desde hace años: no hay un pueblo libre sin la libertad de las mujeres. Desde esta victoriosa marcha del 8 de marzo, donde la cuestión de la mujer sirvió para impulsar la marcha, y sin dudarlo, las jóvenes feministas decidieron formar «un Carré feminista», 
es decir, un lugar donde se movilizarían con pancartas. El viernes I7 de marzo, funcionó sin incidentes. Rápidamente, este puesto de guardia se convirtió en Transgeneracional y la red de Wassyla se unió a la Plaza. El siguiente viernes, 22 de marzo, el teléfono árabe había funcionado y la Plaza se había convertido en un polo de fijación de los islamo-conservadores y de muchos otros que no saben que son islamo-conservadores y que se autoconsideran demócratas. Las cosas salieron mal. Vimos la otra cara del "pueblo" que gritaba «democracia». Estaba claro que no todos piensan que la democracia es, ante todo, la igualdad y que este «todo» también se refería a las mujeres. El Carré feminista se reunió por segunda vez cerca de la verja de la Universidad Central de Argel donde fueron agredidas verbalmente, a punto de serlo físicamente.

Esto provocó un debate Sobre LA CONVENIENCIA DE PLANTEAR AHORA LA CUESTIÓN DE LA IGUALDAD ENTRE MUJERES Y HOMBRES DURANTE EL PROCESO DE TRANSICIÓN. ¿QUÉ HAY QUE PENSAR? ¿CUÁL ES SU OPINIÓN?

Para ser exacta, diría que es jahora o nunca! Esta cuestión está nutrida de una larga experiencia de la historia de Argelia, de otros países y regiones, de largos 25 años de trabajo en las Naciones Unidas y de tanta militancia intelectual en Argelia. Pero es cierto que he sido quebrantada y que sigo siéndolo por ciertas mujeres jóvenes a quienes respecto por su compromiso, que son feministas en su vida pero que no se identifican igual que hacíamos mis compañeras y yo en los 70 y 80, o como lo hacen las jóvenes del Carré (entre 25 y 30 años) que se identifican como tal y luchan por la democracia y la libertad como mujeres y también por las mujeres. Más de una vez me han pedido que revise mi postura. Creo que están equivocadas. Temen que las reivindicaciones rompan el impulso colectivo y separen a los manifestantes. Pero creo que, a la luz de algunas reacciones, han evolucionado sobre este punto, y se dan cuenta de que la cuestión de igualdad es un requisito previo ineludible. Además, todos los días tenemos evidencia de que el poder no escucha la calle, y hace que sea aún más urgente forjar esta pregunta en el corazón del proceso de transición. Ahora, más que nunca, es necesario que las fuerzas progresistas planteen el tema de las mujeres porque después sería demasiado 
tarde. Nos convertiríamos en lo que siempre hemos sido: una moneda de cambio de las diferentes tendencias en una sociedad altamente islamizada y muy conservadora. Entre los que nos asaltaron en Le Carréféministe el viernes 22 , hubo varios tipos de reacciones muy reveladoras: en primer lugar, había algunos jóvenes entusiasmados y quizás en servicio por encargo, y también había mujeres y hombres que expresaban muy claramente su oposición y agresivamente nos decían cuán indignadas estaban por nuestras pretensiones de igualdad con palabras contundentes, como «iesto lo dictó Dios!» o, «estas son nuestras tradiciones» o también, «qué vienen a hacer los tunecinos con su ley de herencia» (una delegación amistosa de feministas tunecinos estuvo allí apoyándonos), etc. Y, finalmente, había unos «hombres razonables» que querían «protegernos» y que nos pidieron ser «sensatas» y esperar a que el sistema se «largue» y se descarte del panorama político para actuar. Estas tres manifestaciones de patriarcado son tan peligrosas las unas como las otras: unos bravucones enviados para asustar, conservadores islámicos y pseudo-demócratas.

Entonces, ¿Cómo Podemos AVANZAR y ASEgurarnos DE QUE EN Argelia finalmente reconozcamos la libertad, LA IgUALdad Y LA DIGNIDAD DE LAS MUJERES?

Desde el inicio del movimiento del 22 de febrero, la presencia de mujeres es muy fuerte y su alta participación es una de las características de este movimiento. El viernes 8 de marzo fue la apoteosis de lo que llamo «el igualitarismo utópico». La historia nos ha obsequiado con este precioso y excepcional regalo que es la convergencia de dos luchas importantes e inseparables de la humanidad en su camino hacia la civilización: la lucha por la democracia, es decir, por la libertad política y de consciencia para todos y el feminismo, es decir, la exigencia de la igualdad de todos los ciudadanos, mujeres y hombres. Después de este 8 de marzo, las mujeres decidieron crear un Carré Feminista para mantener la visibilidad de sus reivindicaciones y continuar manifestándose dentro del movimiento en general. Creo que es una buena decisión, no sólo para las mujeres sino para el movimiento en sí. La reivindicación de la igualdad de las mujeres debe ser entendida por todas las fuerzas del movimiento que pide la democracia. ¡Pero ojo, no es tan obvio! Y es por eso que hay que dejarlo 
claro. Las jóvenes feministas, después de nosotras que somos la generación de la independencia y que también lo sabemos, por su experiencia en el trabajo, en la calle, en la ciudad, en la familia saben que, en general, que cuando se habla de democracia, la sociedad argelina hace oídos sordos. Nosotras pensamos que no hay democracia si no se garantiza la igualdad entre mujeres y hombres. Este requisito no es sólo un requisito moral, sino, eminentemente, político. No podemos lograr la democracia sin ella. Derrida dice que la democracia es el momento mismo de la democracia, y para que este tiempo nos lleve a la democracia, existe el imperativo de respetar el reconocimiento de la igualdad y la libertad de las mujeres, así como el derecho a la libertad de consciencia y el derecho a una sociedad civil administrada por leyes civiles definidas por todas y todos. Todo esto nos lo enseñó la historia, no se lo inventaron estas mujeres que se manifiestan en la calle. Para que haya democracia, todos estos elementos deben estar aglutinados. No hay un pueblo libre sin la libertad de las mujeres.

LA CANTIDAd DE MANifESTANTES, CADA VIERNES, CONTINÚA SORPRENDIENDO AL MUNDO. NUNCA HEMOS VISTO MANIFESTACIONES TAN GRANDES Y PACÍFICAS. ES EXCEPCIONAL Y GRANDIOSO, DA UNA imagen del pUeblo, absolutamente, CONMOVEdora. ¿CREE QUE LOS MANIFESTANTES SABEN LO QUE QUIEREN?

Como bien dice Fanón sobre las primeras marchas de la Independencia, creo que se trata más bien de una «fiesta de lo imaginario». ¿Pero qué es lo que quieren ellos? ¿Qué hay detrás de los esloganes? No lo sé, y probablemente ellos tampoco. Pero sí saben lo que no quieren. Michel Foucault dice que una revolución es decirle no al Rey, y no proponiendo algo. Una revolución no es ni democrática ni feminista. Simplemente Es. Y este es el caso del movimiento del 22 de febrero: los manifestantes que están en la calle desde el 22 de febrero gritan $\mathrm{NO}$ al sistema, piden un cambio sin decir el qué. El régimen los había privado de su dignidad como hombres libres (¿qué significa libres en estas condiciones?). Quieren que los gobernantes se vayan para recuperar su orgullo. ¡Pero el orgullo no es un proyecto político para garantizar nada! Pedir el cambio sin decir en qué y hacia qué, es una aventura. Cuando gritamos democracia ¿qué es lo que decimos realmente? Los incidentes del Carré de la Mujer el 
22 de marzo me obligan a que haga esta pregunta. Por lo que escuché ese viernes 22 de marzo, no me parece a mí que desean un cambio en la familia. Esto plantea un problema real no sólo para las mujeres sino también para la democracia. El esmero de derogar el código civil prendió fuego. Riadh Ben Achour, un destacado jurista tunecino, constitucionalista que presidió la Comisión emplazada en el lugar de la Asamblea en Túnez desde Benali, cuando se le cuestiona sobre la Constitución dice que «la constitución tunecina era el Código de Estatuto Personal. ¡No conviene que el vergonzoso Código de la Familia Argelina, se convierta en la base de la revolución del 22 de febrero! Es necesario que las mujeres y los hombres de este país conciban, reconozcan y acepten que la libertad y la democracia son también para las mujeres. No hay razón para reivindicarlos, es el derecho de las mujeres. Llevamos desde el 5 de julio de 1962 esperando que esto se reconozca. Estos son nuestros derechos y nadie puede «dar» o «usurpar». El tiempo de las quejas ha caducado.

A menudo dice usted Que el tema de las mujeres va más allá DE LAS MUJERES Y QUE ES CRUCIAL PARA TODOS LOS PROBLEMAS. Pero si está tan arraigado en la sociedad entonces ¿Cómo CAMBIARLO? ¿CÓMO ROMPER CON ELLO?

Repito, es ahora cuando debemos plantear el problema. Desde mi experiencia, y conociendo la dificultad de lograr un cambio en el tema de las mujeres y la familia que pondría en tela de juicio la supremacía absoluta de los hombres, es en estos momentos que los historiadores hablan de «efervescencia» que permite que uno pueda conseguir cambios y que la ruptura con el antiguo régimen sea posible. Lo que necesitamos es una ruptura no sólo política sino dentro de las reglas de la familia. Esta es la revolución, una movilización política, pero también en la forma de vivir, de ver, de pensar, de amar. Si cambiamos el sistema con la misma forma de pensar, dentro de io años volveremos a encontrarnos con el mismo régimen que hoy estamos queriendo cambiar. El régimen que tenemos ahora y que todos quieren derrocar es un régimen puramente argelino. Nació de una cierta mentalidad argelina. Y me pregunto ¿Por qué el régimen se convirtió en lo que es ahora? Obviamente, esto no tiene nada que ver con los americanos ni con los franceses, sino porque no hemos 
sabido defender la democracia. Exigir y defender la democracia es ser en sí un verdadero demócrata y no un demócrata a medias. Hay que empezar siéndolo en casa, con sus hijos, sus hijas, su esposa, con su compañero en el trabajo. Algunas personas piensan que estas evoluciones suceden con el tiempo como arte de magia o con tener un bienestar material. Es falso. Esto sería posible si la escuela, los medios de comunicación, la cultura, la religión tuvieran este objetivo. ¿Pero quién decide sobre la escuela, quién decide sobre programas culturales o sobre la televisión? ¿A caso se les pide a las feministas que participen en estos proyectos sociales? Todos hemos visto las dificultades que sufrió nuestra intelectual y feminista ministra de la Educación Nacional. Si seguimos diciendo lo que decimos hoy en las escuelas sobre las mujeres, en las mezquitas, nunca habrá democracia en este país. La lucha de las mujeres es inseparable de lo que se está haciendo para el cambio de régimen. En términos de reflexión es inherente. En el plan de acción también. Tanto las feministas con una larga experiencia del movimiento feminista como las jóvenes feministas con madurez política, saben que en la sociedad argelina la cuestión de la igualdad de las mujeres es minoritaria. También saben que este es el momento, un momento propicio para las rupturas con el régimen, de admitir este principio.

¿QUé ES LO QUE hizo QUE LA VISIÓN DE LA SOCIEDAD SOBRE LA MUJER No EVOLUCIONE? O, MEJOR Dicho, ha EMPEORADO. Y ESTO SE REFLEJA EN EL 90\% DE LAS MUJERES CON VELO, LO QUE DEMUESTRA UN FUERTE SÍMBOLO DE LA JERARQUIZACIÓN DE LOS SEXOS Y EL MODELO SEXUAL ELEGIDO.

El cambio en el seno de la familia es el que más cuesta de conseguir. Lo que impide este cambio es el radicalismo religioso que se presenta como un obstáculo insuperable para algunas personas. Han convertido el estatus de la mujer en algo sagrado, una parte indisociable de la identidad del creyente musulmán, que es una aberración en sí. Es más, antes de este neo-islamismo, la mujer ya estaba secuestrada por una ideología de identidad que se unió a este radicalismo religioso. Lo peor de todo es que se retroalimentan. Nicole Lauroux, una helenista que estudió a mujeres en la antigua Grecia, dijo que las mujeres eran unas «incluidas 
excluidas». Incluidas en la identidad del grupo, portadoras de tradiciones, responsables de representar la tierra, la patria, el grupo. Estos tres elementos están recogidos en Nedjma de Kateb. En un seminario en Tizi Ouzou, las estudiantes de literatura nos sorprendieron y nos deleitaron al analizar este libro desde un punto de vista feminista, enfatizando que Nedjma nunca fue temida como un individuo femenino sino que sirvió para colmar las fantasías patrióticas y delirantes de los tres chicos. Decapante y saludable. Así que la mujer está incluida, pero excluida porque no tiene potestad.

¿CuÁLES SON SUS DESEOS PARA ESTA JOVEN Y FRÁGIL REVOLUCión?

Larga vida y mucho éxito. La clave del éxito son las mujeres, su libertad, su igualdad en nuestra sociedad. No hay pueblo libre sin mujeres libres e iguales. Lo que espero de esta revolución del 22 de febrero de 2019 y de mi país que, desde la solemnidad de este momento histórico que estamos viviendo y que todo el mundo admira, sepan colocar los cimientos de una sociedad basada en la igualdad de mujeres, de hombres y de todos los seres humanos que viven en Argelia, la libertad de consciencia y la solidaridad social. Con estas tres exigencias no significa que queramos ejercitar la tiranía. Lo que espero del movimiento del 22 de febrero de 2019 es que sirva para que tengamos la valentía, la fuerza, la unidad y la confianza para plantear, para el futuro de Argelia, un proyecto basado en estos tres principios que darán los principales tres ejes del proyecto de mañana. La capacidad de presentar un proyecto de sociedad que va más allá de la sociedad en sí solo puede surgir de un gran movimiento popular, utópico y progresista. No es una ley, es una declaración de principios que debe incluirse en la constitución y que debe ser un marco para el maestro (del ministro al maestro), para el hombre de ley (del legislador al juez), para el economista (del planificador al empresario), para la policía y el ejército. Es un proyecto de sociedad y no una tiranía. No debemos decir lo que somos, sino lo que queremos ser. Si no nos planeamos en el futuro, el pasado nos atrapará. Las mujeres no quieren ejercer una tiranía sobre el presente, quieren «dar luz» al futuro. Por eso es transcendental hablar de ello ahora. Por segunda vez en Argelia, tratamos este problema de una manera amplia y global. La primera vez que debió haber sido el 
primer día de la Independencia, se esperó a que el poder se estableciera cómodamente y que su sistema educativo se hiciera machista y cuando comenzaron las negociaciones para la redacción de la Charte Nationale (I976) el proyecto estaba perdido de antemano. La segunda vez es hoy, en 20I9. Las jóvenes feministas tienen la valentía de hacerlo desde dentro del propio movimiento. Han subido al tren de la historia como feministas. En el 62, nosotras, no supimos hacerlo. Por ello quiero pedirles disculpas, porque si están, hoy, frente a tantas dificultades de agresión, de violencia, es porque cuando había que hacerlo en nuestro "Aquí y Ahora», no lo hicimos. Echamos manos de «los hermanos mayores» que nos pidieron postergar. Hoy las jóvenes feministas han comprendido que las luchas siempre están «aquí y ahora» y creo que tienen razón y que la sociedad argelina tiene la suerte de contar con ellas.

\section{Traducción de Naima Benaicha Ziani}

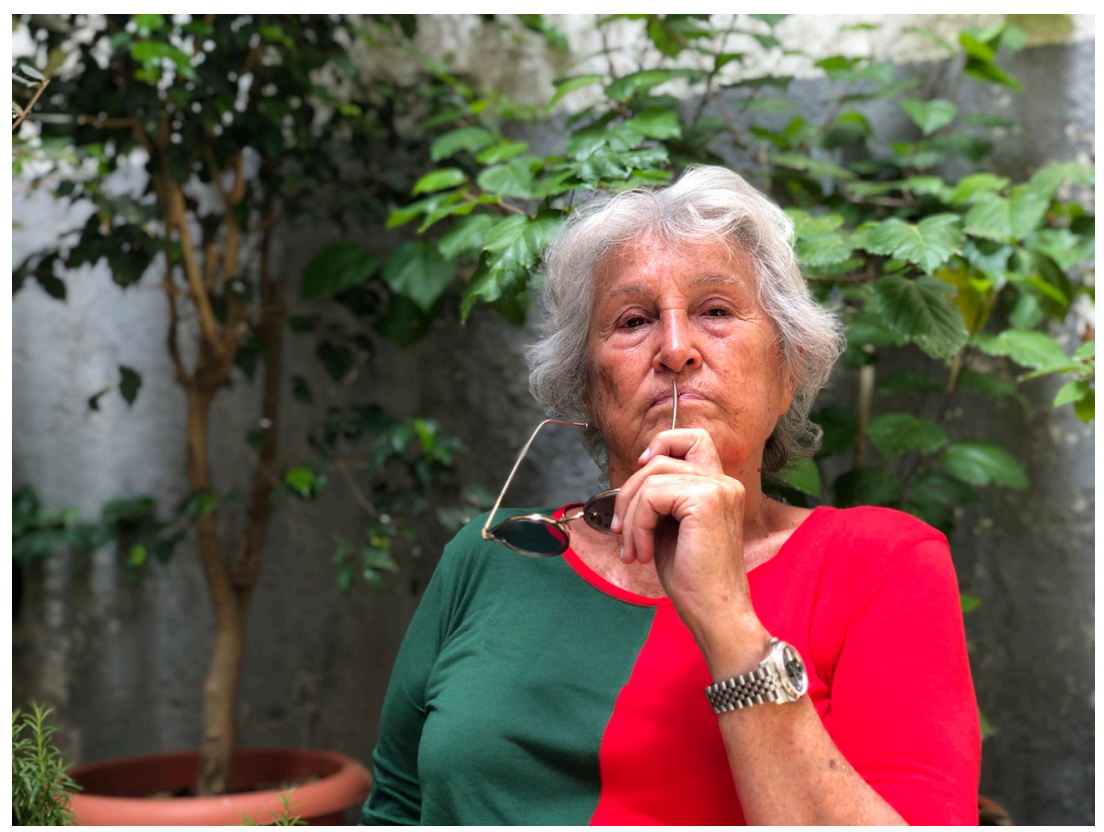

Wassyla Tamzali. Foto de Hichem Merouche 


\title{
UNE ÂME ALGÉRIENNE
}

\author{
AzIz FARÈs \\ Periodista
}

Je me souviens d'un pays heureux.

Écoutez... le chant des vagues douces qui lèchent le rivage dans une danse lascive... érotique.

Laissez vous éblouir par les reflets argentés qui semblent suspendus sur les flots à la recherche d'un moment éternel...

Plongez dans les eaux d'une mer généreuse, porteuse des plus hautes destinées, et laissez vous emporter par le tendre vent qui pousse les navires vers de nouvelles aventures.

Ulysse est aux commandes du navire amiral et Hercule repousse les limites du monde.

Nous sommes dans la légende...

Au loin , la ligne d'un horizon fragile vacille entre le crépuscule et l'aube tel un phare qui guide la route de nos envies.

Soleil d'un été qui s'impose pour nous permettre de nous ressourcer en retrouvant les signes de notre longue histoire.

Soleil du désert qui fait résonner nos pas dans un silence absolu.

Mais il faut savoir écouter... et écouter encore... des milliards de grains de sable crissent sous nos pas pour emporter les dunes immobiles qui se déplacent dans un mystère impénétrable avant de se poser en nous offrant de nouveaux repères.

Tendez l'oreille pour percevoir le chant des oliviers millénaires qui ont connu nos illustres ancêtres. Oliviers généreux dont les branches touchent le sol rocailleux avant de repartir à la conquête des cieux qui acceptent de partager les huiles essentielles que fabriquent les dieux.

Les palmiers majestueux dodelinent au soleil en ancrant leur mémoire dans les eaux profondes du temps. Don du désert, don du ciel, don des dieux, don de l'amour... les dattes et le legmi font frémir de plaisir nos 
palais et nous fermons nos yeux pour entrevoir la furtive étincelle d'un bonheur éphémère mais si proche qu'il nous faut mériter .

Regardez... les troupeaux paissent tranquillement des herbes au goût sucré, subtil mélange de thym, d'armoise et de senteurs inconnues.

Des moutons dociles rejoignent le berger qui d'un léger et savant coup de bâton donne au chien fidèle le signal du retour. Les veaux tètent tendrement le sein de leur mère et les chèvres gourmandes montent sur des arbres décharnés qui ont su résister à toutes les batailles.

Les villes se recroquevillent dans les bras accueillants d'un oued; Le M'Zab lance un appel et la paix se révèle dans les sourires heureux des enfants au regard studieux.

Montagnards courageux, les amaxigh cultivent une terre parfois ingrate qu'ils ont su apprivoiser et qui nourrit tout un peuple de ces fruits qui nous font retrouver un paradis que l'on croyait perdu. Noires, vertes, les figues fraîches se métamorphosent en un délice secret.

Des prénoms se transmettent de père en fils et de mère en fille pour raconter une Histoire vivante qui ne s'est jamais arrêtée.

\section{NOTRE HISTOIRE}

Princesses aux yeux ardents que courtisent des princes amoureux, fiers chevaliers dont le sens de l'honneur rivalisent de courage, rois justes et reines de beauté, la Terre se souvient des gens qui l'ont aimée.

Dans un ultime effort les derniers rayons du soleil déchirèrent les flots tranquilles qui commençaient à se retirer des berges pour se préparer à la nuit.

Les eaux avaient changé de couleurs, passant du bleu à l'ocre puis dans un éclat sublime resplendirent en offrant à nos yeux des milliers de gouttelettes aux tons d'un or profond, précieux présent d'une nature amoureuse.

\section{LE CEEUR DE LA RÉVOLUTION BATTAIT}

Les rues se gonflaient des chants de liberté. Les amants se tenaient par la main emportés par une douce et sensuelle frénésie. Les enfants chantaient et leurs parents les couvaient d'un œil qui laissait perler une larme d'espoir. 
C'était le matin. Je venais d'ouvrir les yeux sur la terre qui m'avait vu naître. J'embrassai du regard les sommets enneigés des montagnes et senti les effluves des herbes hautes qui embaumaient l'air du nouveau printemps.

\section{JE RESPIRAIS}

Quelques nuages aux formes étranges se laissaient emporter par le vent tiède de l'été. Nuages blancs ou transparents qui filtraient les rayons d'un soleil vital et bienveillant.

Un souffle puissant réveilla les flammèches qui se mirent à crépiter emportant le bonheur vers des abysses insondables.

Le chaud et le froid s'affrontaient en un combat épique. Les voix des innocents se mêlaient dans une plainte sourde. Le malheur avait pris la place, chassant d'humeur égale le bonheur interdit. Le rictus de l'Ange se transforma, métamorphose insaisissable, assouvissant les désirs les plus secrets. Visages inquiets mais soumis sans espoir à l'intransigeante et implacable volonté.

Les cris s'entrechoquaient sur des mâchoires édentées. la fournaise s'activait et les coupables trouvaient enfin leur récompense.

Le Diable, Satan en personne, Chaytan, le Succube, l'Ange Exterminateur, TOUS réunis en conclave, décida d'ouvrir la porte pour provoquer un appel d'air sulfuré.

Les trompettes de la mort se mirent à hurler. Dans un seul mouvement les milliards d'êtres humains que le Monde avait vu naître depuis cette fameuse nuit, se mirent en route. Le Diable, les yeux fermés, regardait la cohorte des âmes qui avançait à reculons.

\section{LA GUERRE NE FAISAIT QUE COMMENCER}

Soudain...

Soudain... Les oiseaux de paradis poussèrent un long soupir, les colombes de la paix changèrent de couleur, les angelots se mirent à ricaner, les vierges et les pythies s'agenouillèrent, les cloches des églises ne « raisonnaient » plus, les minarets devinrent muets et le chofar aphone hoquetait dans un râle. 
SILENCE QUI RENDAIT POSSIBLE L'IMPOSSIBLE

La peur disparut, les mains jointes se tendirent pour tenter d'atteindre l'ultime vérité.

Puis ce fut le silence. Silence des regards, silence des gestes, silence des mots, bouches décousues telles des linceuls transparents; silence des sens qui se multipliaient en faisant tourner une girouette affolée .

Silence. Silence.

SILMYA

L'homme et la femme se regardèrent. Et sans dirent un mot, ils murmurèrent ensemble un chant sacré...

«Je me suis perdu dans le bleu outremer de la Méditerranée.

Je me suis perdu sur les murs immaculés d'Alger la Blanche.

Je me suis perdu dans les sables mouvants du désert qui avance en silence.

Je me suis perdu dans les yeux de la belle Lalla Kheididja qui veille sur le destin des hommes libres.

Je me suis perdu dans les gorges profondes des Aurès qui abritent des secrets millénaires.

Je me suis perdu dans les venelles discrètes et enchevêtrées comme des liens solides des Casbahs accueillantes de mon Histoire.

Je me suis perdu dans les bras amoureux des filles de mon pays.

Je me suis perdu dans les accolades chaleureuses de mes frères d'armes, compagnons de combats épiques, de victoires glorieuses, de défaites exemplaires.

Je me suis perdu dans les mains douces qui roulent le couscous.

Je me suis perdu dans les tatouages ésotériques qui ornent le front, les mains, les jambes et les bras qui affichent leur identité.

Je me suis perdu dans les chants populaires qui vibrent au son du violon, du banjo, de la kamendja, du mandole et de la derbouka.

Je me suis perdu dans la voix des grands mères qui savent raconter en caressant le front des enfants assoupis.

Je me suis perdu dans l'appel vrai et sincère du muezzin qui éveille les sens. 
Je me suis perdu dans la plainte de ma chienne abattue d'un coup de crosse.

Je me suis perdu dans les palmeraies des délices sucrés.

Je me suis perdu dans le délire des mots qui virevoltent en tamazight.

Je me suis perdu dans les tableaux au henné qui mettent en valeur des jambes élancées.

Je me suis perdu dans le regard des enfants qui jouent aux osselets, à la marelle ou aux billes.

Je me suis perdu dans le burnous de mes grands-pères au visage serein, dans la djebba de mes grands-mères qui dessinent la vie, dans le tintement des bracelets de mes tantes qui appellent à la prière.

Je me suis perdu dans le sein tiède de ma mère, dans la main rassurante de mon père et dans les encouragements fraternels.

Je me suis perdu sur la route de mes exils.

Je me suis enfin perdu pour retrouver mon âme ».

Alors et alors seulement, l'âme vagabonde s'élança vers les cieux et la Terre Algérienne donna naissance au nouveau jour qui venait de se lever.

Par Aziz Farès, journaliste, auteur, essayiste « La tangente impossible », «J'ai failli égarer Dieu » ( suivi du troisième œil ) ( editions Milles feuilles Alger ) et «L'encre des savants est plus sacrée que le sang des martyrs » (Editions XYZ Montréal ). 



\title{
Titles \& Abstracts Addenda
}

\author{
Articles \& Critical Notes Section
}

\section{The Popular "Hirak": The New Algerian Revolution \\ Rafael Bustos García de Castro}

\begin{abstract}
This article argues that the Algerian Hirak protest movement is a singular and exceptional case, which differs from both the "Arab Spring" and the "Algerian Spring" (I988-I992). It draws its special characteristics and strength from the Independence War (I954-I962) while it is mainly being conducted through peaceful means. We also examine the current situation of political impasse once the Constitutional procedure has been exhausted and the possible paths to democratic transition that are now being discussed, taking a look at how the most notorious international actors have so far reacted to the Algerian Hirak.
\end{abstract}

Keywords: Algeria, Hirak, demonstrations, Arab Spring, Independence war, empowerment, democratic transition and civil society.

To cite this article: Rafael Bustos García de Castro, "El "hirak" popular: la nueva revolución argelina”, Revista Argelina 8 (Otoño 2019): 27-35, DOI: 10.14198/RevArgel2019.8.04

To link to this article: https://doi.org/Io.I4I98/RevArgel20I9.8.04

The Popular Movement In Algeria: Towards A Systemic Break?

On The Socio-Historical Roots Of The Algerian Crisis

Adel Abderrezak

\begin{abstract}
The purpose of this article is not to relate the recent popular movement in Algeria, nor to make a chronology of events. We have to historically recontextualize this system of power in its political and economic dimension in order to understand how the Bouteflika cycle ended.
\end{abstract}

Keywords: Popular movement, system, power, economy, politics.

To cite this article: Adel Abderrezak, "Le mouvement populaire en Algérie : vers une rupture systémique ?", Revista Argelina 8 (Primavera 2019): 37-49, DOI: 10.14198/RevArgel2019.8.05

To link to this article: https://doi.org/ro.I4I98/RevArgel20I9.8.05

The Look Of Dib And Camus On The Algerian Landscape

Brigitte Leguen

\begin{abstract}
Mohamed Dib and Albert Camus were both born in Algeria surrounded by the same landscape. In this article we will analyze how each perceives space and its meanings.
\end{abstract}


Keywords: Literature, space, landscape.

To cite this article: Brigitte Leguen, “Le regard de Dib et Camus sur le paysage algérien”, Revista Argelina 8 (Primavera 2019): 51-58, DOI: 10.14198/RevArgel2019.8.06

To link to this article: https://doi.org/Io.I4I98/RevArgel2oI9.8.06

The Social Left And Political Islam: The Algerian Experience

ILYA U. TOPPER

\begin{abstract}
Islamism as a political ideology reached world-wide prominence after the revolution against the Shah in Iran in 1979, where Marxist and Islamist groups joined forces. Although Khomeini destroyed the Left afterwards, Islamism is still considered as a leftist movement for its percieved opposition to the US. Islamist movements replaced Marxists in many Arab countries thanks to a strong support by autocratic regimes who fostered them in order to weaken the left-wing opposition, a phenomenon obvious in Algeria. During the Arab Spring, Islamists took over the secular uprisings (Egypt, Syria) or shaped an alliance (Morocco). Nevertheless, any coalition by democratic and Islamist forces usually leads to the destruction of the former by the latter: The goal of Islamists is to rule society by divine laws that cannot be questioned, especially when it comes to women's rights. Democratic forces in the uprising in Algeria today should avoid such an alliance.
\end{abstract}

Keywords: Islamism, Algeria, democracy, Arab Spring, Left-wing, women.

To cite this article: Ilya U. Topper, “La Izquierda social y el Islam político: la experiencia argelina”, Revista Argelina 8 (Primavera 2019): 59-73, DOI: 10.14198/RevArgel2019.8.07

To link to this article: https://doi.org/Io.I4I98/RevArgel2019.8.07

\title{
Algeria: Uncertain Transition Amid Announced Political Crisis
}

\section{Laurence Thieux}

\begin{abstract}
After decades of political immobility, Algeria has known since February 22, 2019 profound transformations that question many of the preconceived ideas about Algerian society. The mass, peaceful and prolonged demonstrations of the Algerian population against the political system are unprecedented and revealing of the profound changes that have transformed both society and the Algerian governance system over the past two decades. The article provides a reflection on the economic, social and political factors that explain the political and institutional crisis and on the role of the army in this process.
\end{abstract}

Keywords: Civil society, National People’s Army, transition, youth, social networks.

To cite this article: Laurence Thieux, "L'Algérie transition incertaine sur fond de crise politique annoncée", Revista Argelina 8 (Otoño 2019): 75-84, DOI: $10.14198 /$ RevArgel2019.8.08

To link to this article: https://doi.org/Io.I4I98/RevArgel20I9.8.08 


\section{Criterios de edición:}

Revista Argelina. Revista semestral de Estudios Argelinos es una publicación electrónica e impresa evaluada por pares con tres criterios de selección: I) aceptación; 2) aceptación con cambios; 3) devolución. Se aceptan contribuciones en castellano, valenciano, árabe, francés e inglés.

Los originales se presentarán registrándose como usuario y subiendo el documento a la plataforma ojs de gestión del proceso editorial en el sitio web: https://argelina.ua.es

El aparato crítico deberá ajustarse a las siguientes normas de edición:

-Texto en formato estándar a un espacio de interlineado.

-Fuente en Romanas (Times New Roman) a I2 puntos.

-Título del trabajo en mayúsculas a I6 puntos seguido en línea inferior por el nombre del autor en versalitas.

-Notas a pie de página a ro puntos.

-Cita: Libro (Nombre, Título, Ciudad, Editorial, Año); Artículo (Nombre, “Título”, en Revista, Año, vol. x, núm.x, pp. xx).

-Sistema internacional para las citas y transcripciones del árabe. 


\section{معايير النشر :}

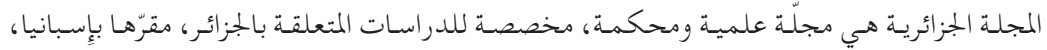

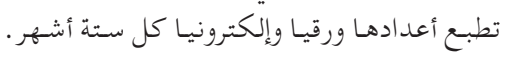

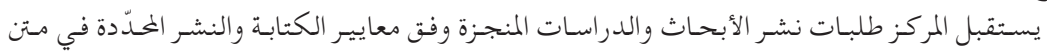
هـذه الوثيقـة.

- تخضع المواد المرسلة كلّها للتّقييم والقراءة الأكاديميّة . - في حال الموافقة، يُجري الكاتب التعديلات كليات المقترحة قبل تسليم المادّة للتحرير النّهائي.

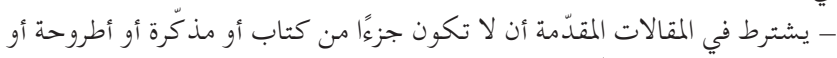

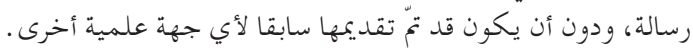

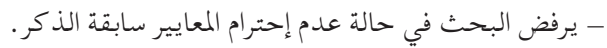

يمكن المساهمة باللغات التالية : العربيّة، الإِسبانية، الفرنسية، الفلنسيانية والإِنجليزيّة.

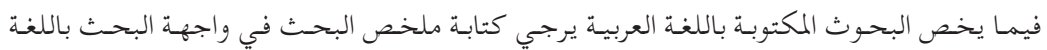

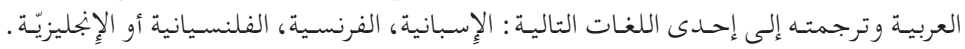

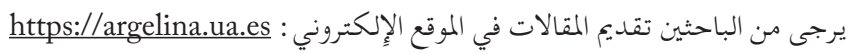

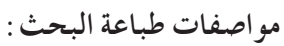

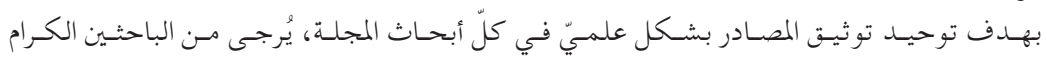

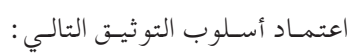

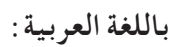

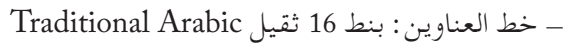

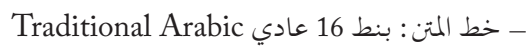

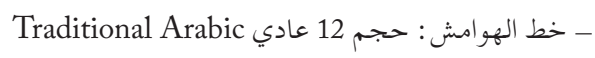
باللغات اللاتينية: - تنسيق النص القياسي في مسافة سطر . بالغات

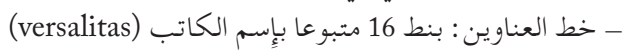
- خط المتن: بنط 12 عادي (Times New Roman)

- الإشارة إلى الهو امش أسفل الصفحة بالطريقة الالكترونية، بنط 10 (Times New Roman)

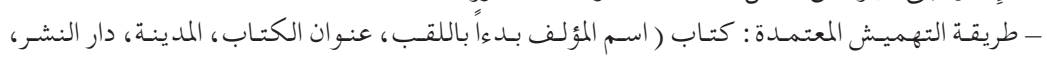

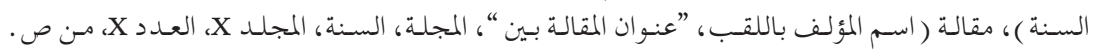

- يرجى استعمال النظام الدولي للتعيينات والنصوص العربية . - يلي كل مقالة قائمة المراجع والمصادر المعتمدة عليها في البحثث. 



$$
\text { العدد الثامن • ربيع } 2019
$$

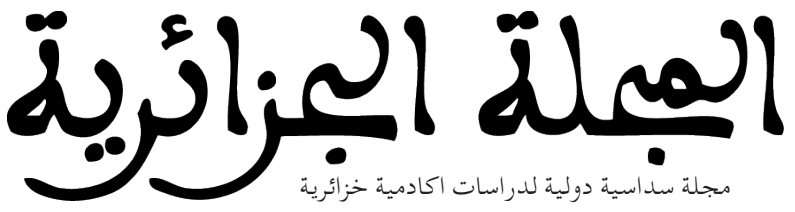




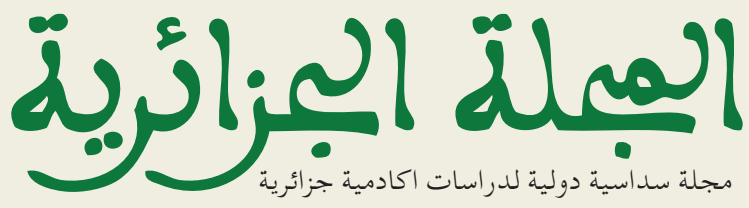

\section{ÍNDICE}

Editorial

\section{Ensayos}

Natalia Molinos Navarro y Jaume Marzal Canós

Argelia y España, un amor de ida y vuelta....

Karim АкоUche

El futuro de Argelia en seis actos

Artículos y notas

RAfael Bustos García de CAstro

El "birak" popular: la nueva revolución argelina

Adel Abderrezak

Le mouvement populaire en Algérie: vers une rupture systémique? Sur les racines socio-bistoriques de la crise algérienne

BRIGITTE LEgueN

Le regard de Dib et Camus sur le paysage algérien

ILYA U. TOPPER

La Izquierda social y el Islam político: la experiencia argelina

Laurence Thieux

L'Algérie transition incertaine sur fond de crise politique annoncée

\section{Reseñas y comentarios bibliográficos}

Nabil Ziani, Les berbères dans la Bible. Des origines à la fin des temps (N. Benaicha Ziani) ........... 87

Hugh Roberts, Berber Government: The Kabyle Polity in Pre-Colonial Algeria (A. Torres Fernández) ............ 91

Mustapha Chérif, Tolerancia e intolerancia en el islam (I. Donoso) .................................................... 93

\section{Biblioteca}

Wassyla TAMZALI

El feminismo ante el Movimiento del 22 febrero: la revolución por las mujeres (Entrevista traducida del francés por Naima Benaicha Ziani)

AzIz FARÈs

Une âme algérienne.

Titles \& Abstracts Addenda 